Portland State University

PDXScholar

Spring 6-12-2013

\title{
Rural Revolution: Documenting the Lesbian Land Communities of Southern Oregon
}

Heather Jo Burmeister

Portland State University

Follow this and additional works at: https://pdxscholar.library.pdx.edu/open_access_etds

Part of the Gender and Sexuality Commons, and the Women's History Commons Let us know how access to this document benefits you.

\section{Recommended Citation}

Burmeister, Heather Jo, "Rural Revolution: Documenting the Lesbian Land Communities of Southern Oregon" (2013). Dissertations and Theses. Paper 1080.

https://doi.org/10.15760/etd.1080

This Thesis is brought to you for free and open access. It has been accepted for inclusion in Dissertations and Theses by an authorized administrator of PDXScholar. Please contact us if we can make this document more accessible: pdxscholar@pdx.edu. 


\title{
Rural Revolution:
}

Documenting the Lesbian Land Communities of Southern Oregon

by

\section{Heather Jo Burmeister}

A thesis submitted in partial fulfillment of the requirements for the degree of

\author{
Master of Arts \\ in \\ History
}

Thesis Committee:

Katrine Barber, Chair

Patricia Schechter

Ann Mussey

Tim Garrison

Portland State University

2013 


\begin{abstract}
Out of the politically charged atmosphere of the 1960s and 1970s emerged a migration to "the land" and communes, which popularly became known as the back-tothe-land movement. This migration occurred throughout the United States, as well as many other countries, and included clusters of land based communities in southern Oregon. Within these clusters, lesbian feminist women created lesbian separatist lands and communes. These women were well educated, and politically active in movements such as the New Left, Civil Rights, Women's Liberation, and Gay Liberation. These lands or communes functioned together as a community network that developed and commodified lesbian art, which impacted and influenced the development of lesbian art over time.
\end{abstract}

In Oregon, as of 2011, at least ten known lesbian lands still existed. This cluster belonged to an extended community that stretched down into California and over into New Mexico. Over a two-year period I collected, transcribed, and studied the oral histories of eight of the elders of the women's land movement in southern Oregon. The purpose of this study is to better understand this movement of lesbian feminists the development of lesbian art and culture over time. The lesbian feminist back-to-the-land movement made the conscious choice to disengage from the patriarchal mainstream rather than continue participation in their own oppression. They viewed lesbian feminist separatism and the creation of safe lesbian land as a way to reconstruct their self-identity 
and influence the continued self-perception of lesbians the world over through art and literature.

Based on these oral histories and archival materials, it became evident that the women within the lesbian land communities developed and maintained land on which they could re-examine who they were, re-educate themselves and each other, learn practical skills, construct new identities, create art, and broadcast their creations out into the world through organized media networks.

One of the key features of this construction of lesbian land culture was the desire to share--share power, share money, share responsibilities, share knowledge, share land, share lovers. On the one hand, ownership was eschewed as elitist and patriarchal, while simultaneously important to the continuity of women's land and its protection from what could be described as patriarchal profit motives. They developed infrastructure, altered language, created a spiritual practice, and made art. The material and artistic culture was created in concert with modes or mediums of transmission, casting it out to a much wider audience. These creative activities influenced and impacted women beyond Oregon, beyond the lesbian land communities, and beyond the 1970s.

By examining the lesbian land movement in southern Oregon, we can better understand the impact on LGBTQ culture, and the continued albeit unintentional impact on the questioning of the gender binary and sexual identity. In other words, the feminist and queer questioning of identity construction and symbolic language began here. 


\section{Acknowledgments}

It is not very often that I am given the opportunity to publicly and permanently acknowledge individuals without whom I could not have attended college and completed this thesis, so forgive me if I go on a bit. First and foremost, I want to acknowledge Jim and Gloria Burmeister, the best grandparents and backup parents that anyone could ask for--without them I would not have developed such a keen interest in the world of reading, writing, and knowledge. They both died during the course of my studies, but I know that they are proud of me. Similarly, my father and mother, David and Cynthia Burmeister, offered nothing but encouragement throughout these years. Without them, I would not have learned the values of persistence and perseverance. Some of us just have to work harder than others.

One of the biggest obstacles to education in this country is money. Some people are born with it. Some are fortunate enough to have the advantages and sheer luck that enable them to land a perfect job, and earn the money to afford an education. When I first started college I took one evening class each term and paid cash. Without the help of the (Portland Community College) PGG Foundation I would not have been able to attend school full-time. I am forever grateful to them. I could not have collected all of the oral histories that I did without the financial assistance of the Oregon Heritage Commission, and the presentation I gave at their annual meeting was important to my professional development. I am so grateful for that opportunity. Thank you. My last two years at Portland State University were not easy on the pocketbook. In the end I turned 
to networking and crowd funding to pay for these last two terms. I am humbled by the generosity of others. An old friend of mine once said, "The world is full of people who want to help you achieve your dreams. They want to give you what you need, but first you have to ask." I asked, and Amos Turner, Ellen Bartell, Heather Pundt, Avi Brockman, Dale Schiff, Heather Bishop, Sasha Goddard, Emily Stuckman, Anita Rodgers, Erica Eynouf, Patrick Barry, Deborah Gitlitz, Rachael Cook, Darla McBryde, Katy Barber, Chelinda Molyneux, David Fruchter, Jan Dilg, Marie Timbreza, Melani Smith, Chloe Massarello, Mattias Olshausen, Stacy Bias, Natalie Cooper, Patrice Mays, Megie Shean, Sue Burns, Rebekah Hope Clark, and Trina Timbreza answered with the funds I needed. I hope that one day, when asked, I can help someone else. Thank you.

I could not have written as well as I did with out the guidance and persistence of my instructors. I have always been drawn to whichever task is the most difficult or intimidating, and public history is certainly a challenge worth meeting. I thank Katy Barber, Patricia Schechter, and Bill Lang for the challenge. Thank you for pushing me to think harder and write better than I ever imagined. Similarly, I would not be the same person I am today, without Tim Garrison's series of constitutional history courses. As someone who is terrible at remembering names and dates, Prof. Garrison challenged me to not only remember them, but to also associate those names and dates with causes and effects, justices and constitutional law, and the big picture. I more proud of every 'B' I earned in his courses, than I've ever been for every 'A' I received in any other class. Thank you. So much of an education is also dependent upon the readings and assignments that an instructor imposes upon his or her students, and I very much appreciate the choices that Professors Belco, Schuler, and Mussey made in their courses. I 
appreciated the challenges, and the subsequent shaping of my thinking and abilities.

Thank you.

Oral history is not possible without the cooperation, time, trust, and energy of those we interview. I have nothing but respect and gratitude for Bethroot Gwynn, Hawk Madrone, Jean Mountaingrove, Billie Miracle, Jemma Crae, Dana MacDonald, Zarod Rominski, and Tangren Alexander. I also want to thank Linda Long, Musawa, Sue Burns, Barb Dickinson, Myshkin, Sailor, Francis Etherington, Ní Aódagaín, Sierra Lonepine Briano, Annie Ocean, Maggie Jochild, and many others who took the time to connect with me.

I would not have survived and thrived without the camaraderie, love, and support of my fellow PHIGs: Heather Petrocelli, Jeff Baker, Doug Kenck-Crispin, MaKenzie Moore, and Lisa Donnelly. You all are more amazing and precious than you know. xo Finally--Elisa Ross--one day I will make this all up to you, please forgive me for all of my selfishness. I love you to the moon and back. 


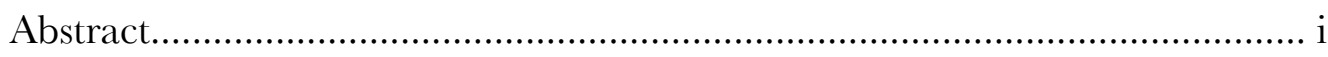

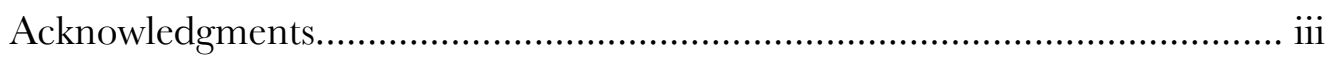

Preface: A Note On Language................................................................... vii

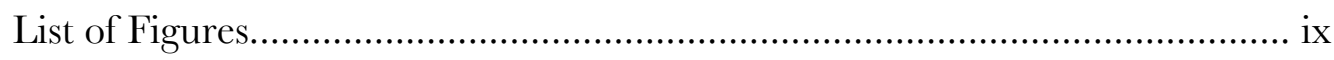

Chapter 1: Introduction....................................................................... 1

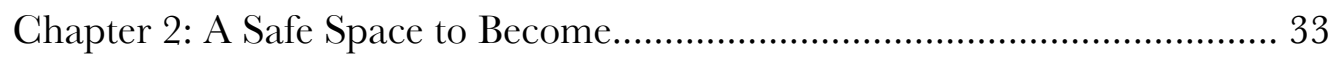

Chapter 3: A Time to Create Lesbian Culture............................................. 54

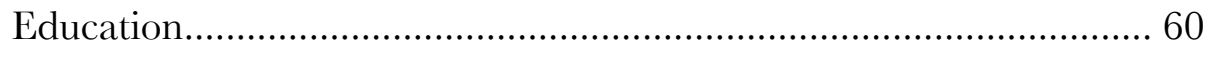

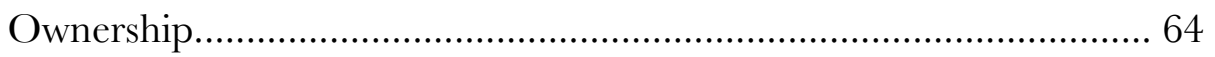

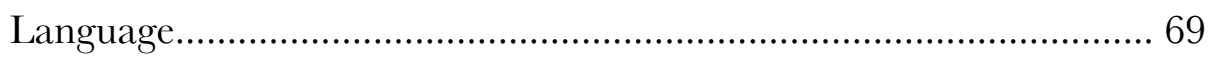

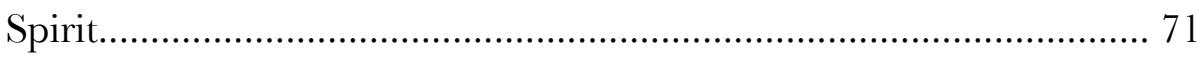

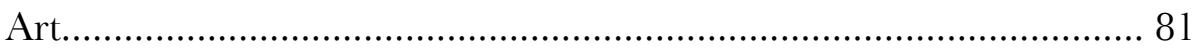

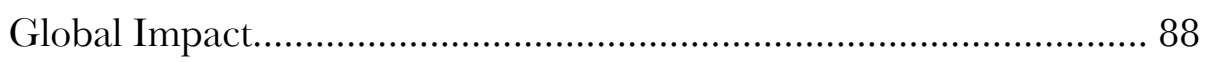

Chapter 4: Keeping Women's Land for Women......................................... 95

Chapter 5: In Conclusion............................................................. 115

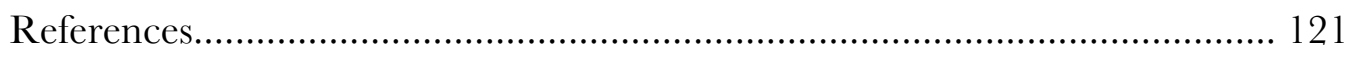

Appendix: Women's Land Chronology............................................... 131 


\section{Preface: A Note On Language}

Women within the lesbian feminist separatist movement of the 1970s and 1980s consciously chose to adopt new words and alternative spellings, in an effort to erase patriarchy from language. These choices included alternate spellings of:

$$
\begin{aligned}
& \text { women/woman= wemoon, womon, womyn, etc. } \\
& \text { history= herstory } \\
& \text { seminar= ovular }
\end{aligned}
$$

Partially because I am not of that movement or generation, and for readability, I chose to include these alternate words and spellings only in instances when I am quoting or paraphrasing an informant or writer who has made that word choice. Otherwise, I chose to use terminology that is commonly understood, such as "history" when referencing the study of the past and women when speaking of an individual who claims that particular gender identity.

The lesbian lands of southern Oregon are sometimes referred to as women's land, lesbian land, lesbian separatist land, lesbian intentional communities, and lesbian feminist land. All of these phrases are accurate descriptors. The women interviewed in this thesis and those who have studied them (myself included) often use these phrases interchangeably. Similarly, those within the community and writers have often used land women, country women, land lesbians, and landdykes, using a variety of spellings, as identifiers. I hope that this explanation prevents any future confusion.

On another note, I tried to pay particular attention to my use of the word "commune." There was a time period in the early 1970s when this term might have been appropriate for what the lesbian land communities where attempting, but that was 
relatively short lived. Most of the women I spoke with preferred the use of the term community or intentional community to differentiate themselves from many of the hippie and other communes that were both simultaneously and geographically close to them. 


\section{List of Figures}

Figure

Page

1

Fly Away Home 2011

27

2

Portland WomanSpirit 1975

75

3

Front Cover, Summer 1984 issue of WomanSpirit magazine 77

4

Baltimore, MD. Diana Press 1976

83

5

Golden office, loading WomanSpirit for distribution at the post office 1977

Ovular 2, Rootworks 1980

91 


\section{Chapter 1: Introduction}

And I have to say that when I see the life I've made, and what I see is that I became committed to what we called, in those days, cultural feminism. Well, from a certain hard-edged leftist perspective, cultural feminism is counter-revolutionary. It's not in the barricades. It's creating an alternative world. I wasn't alone in creating that niche, because Barbara, Mark, and Spes and I were all in there together--and our friend Claudia from Iowa, and countless other women doing the same kind of things.

--Bethroot Gwynn ${ }^{1}$

As of 2011, there were at least ten publicized in women's media, and possibly more than fifteen unpublicized women's lands in southern Oregon. In the context of this thesis women's land references lands owned and inhabited by women who self-identify as lesbian, lesbian feminist, or lesbian separatist feminist. Some were initially a part of the larger back-to-the-land movement that began in the 1960s. The ALIC, Association of Lesbians in Community, website listed ten, and acknowledges that there are more. My informants stressed that there are lesbians on privately owned lands or land that prefer to remain hidden, who may or may not welcome visitors or new community members, but whose presence is a valuable part of the larger country lesbian community. The ten lands called-out by ALIC include: OWL Farm, Rainbow's End, Raven Song, Rootworks, Steppingwoods, We'Moon Land, WomanShare, Cabbage Lane, Copperland, and Fly Away Home. ${ }^{2}$

\footnotetext{
${ }^{1}$ Bethroot Gwynn, interview with author (3 January 2011), 37.

${ }^{2}$ I know of ten for certain, but the more time I spend with these women the more I discover. The ALIC (Association of Lesbians In Community) website (www.alicinfo.com) lists ten, and acknowledges that there are more. The ten lands called-out by ALIC include: OWL Farm, Rainbow's End, Raven Song, Rootworks, Steppingwoods, We'Moon Land, WomanShare, Cabbage Lane, Copperland, and Fly Away Home. This number also does not include the newer communities that have been trending toward gender inclusion.
} 
In this thesis I will argue that the lesbian lands in southern Oregon had a significant impact on the development of lesbian feminist culture in the 1970s and 1980s, a kind of rural revolution. First I will show how the lesbian land communities that were developed in southern Oregon in the 1970s created a safe space for women to recreate themselves, and to construct and express that identity through art, spirituality, and other forms of creative culture. Then I will show how that culture developed and changed over time, and how the interactions between rural and urban women shaped that culture. Finally using primary source materials and oral histories I will show how the cultural activities of the southern Oregon lesbian lands reached a wider lesbian feminist audience through media networks, thereby solidifying their presence in lesbian culture today. Before addressing these contentions, I will provide historical context for this movement and the movements that influenced it. I will examine the existing scholarship to which this thesis belongs, and lastly address questions of methodology and research.

The women's land movement, as it is often called, was an offshoot of the 1970s back-to-the-land movement, which grew out of a generational opposition to the postWorld War II culture of consumption and commodification. The men and women of the back-to-the-land movement wanted to return to or create anew a culture that they believed was natural and unspoiled. ${ }^{3}$ In the broadest sense, they sought meaningful lives. ${ }^{4}$

3 This movement also belongs to a longer history of utopian communities, stretching back to the beginnings of this country. Historically people sought out communes or intentional communities because they saw something wrong with mainstream society. One could argue that the European colonization of America began as a grouping of intentional utopian communities. Many early colonial writers referred varyingly to America as both the biblical Eden and Hell, depending upon the season. See Kopp, 22-25.

4 Sue, Nelly Dian, Carol, Billie, Country Lesbians: The Story of WomanShare Collective (Grants Pass, Oregon: WomanShare Books, 1976), vi. 
The back-to-the-land movement appears to recur throughout American history in cyclical waves, most of its adherents, longing for a romanticized version of an early America, which in reality never existed. The two largest back-to-the-land movements, occurring in the 1900s and 1970s, idealized farm labor and the rural community of the past. ${ }^{5}$ The 1900 s back-to-the-land movement, which peaked around 1910, focused on labor and a man's right to labor, whereas the 1970s movement sought to maximize the fruits of one's labor. The men and women of the 1970s movement saw labor as a way to gain freedom and free time, as opposed to a value in and of itself or a means to acquire money to buy stuff. Not all of these communities wanted radical change; some individuals and communities fought against societal change or sought to go back in time to a better or simpler past, whether real or imagined. ${ }^{6}$

Southern Oregon became a popular destination for back-to-the-landers in both eras, but especially in the 1970 s, due to the beautiful natural landscape, fertile soil, cheap land, and close proximity to northern California, where hippie and countercultural communities had already established themselves. ${ }^{7}$ An incredible number of individuals, families, and groups forming communes moved to southern Oregon, and purchased dilapidated farms and forested acreage. The back-to-the-landers sometimes settled into existing rural communities, but more often than not separated themselves from those existing rural communities that did not take kindly to being invaded by what they

\footnotetext{
${ }^{5}$ Kopp, 122-124. See also Dona Brown, Back to the Land: The Enduring Dream of Self-Sufficiency in Modern America. Madison: University of Wisconsin Press, 2011.

${ }^{6}$ Marlyn Klee-Hartzell talks a bit about this in the introduction to: Chmielewski, Wendy E., Louis J. Kern, and Marlyn Klee-Hartzell. Women in Spiritual and Communitarian Societies in the United States (Syracuse, N.Y.: Syracuse University Press, 1993), 1-8.

${ }^{7}$ Miller, 69-77.
} 
considered an unruly bunch of hippies. ${ }^{8}$ The rural communities of southern Oregon were not alone in this sentiment. Throughout much of the nation, young people moved from the cities to rural areas, drawing the attention of the national media. ${ }^{9}$

Before the 1970s back-to-the-land movement and the rise of the New Left, young people agitated for change, spurred by the widening economic gap and the stark difference between the American dream and the American reality. ${ }^{10}$ Women started consciousness-raising groups, commonly referred to as CR groups, and organized women's liberation meetings. Women of the New Left published and distributed political newsletters, books, and tracts. Women within the gay liberation movement organized meetings, demonstrations, and made coffee. Gay liberation women witnessed as feminist goals and objectives took a back seat to an almost exclusively gay male political agenda, and so eventually left those organizations to form their own. ${ }^{11}$ Likewise, many gay women felt unwelcome in a women's liberation movement whose efforts to appeal to mainstream heterosexual women left little room for radical feminism and lesbian feminists. ${ }^{12}$ Many of these political activities challenged and influenced the lesbians within this study.

\footnotetext{
8 This is evident throughout the Oregonian and other newspapers between 1967 and 1974. For example see the Sunday Oregonian. August 24, 1969: 115. See also Bob Olmos, "Conflict in The Valley of The 'Wasps'," The Sunday Oregonian. April 27, 1969, 169.

${ }^{9}$ See, for example, the cover of Life Magazine. July 18, 1969, which features a photograph of members of the Family of the Mystic Arts, and the authors spent time on the commune in Sunny Valley, Oregon.

${ }^{10}$ Much of this has been discussed in U.S. history textbooks such as Eric Foner. Give Me Liberty! An American History (New York: W. W. Norton \& Co., 2006), 864-885. -as well as more specialized historians.

11 This is referencing the beginnings of Gay Women's Liberation meetings, which addressed women's liberation generally, and gay women's liberation specifically. This issue can be dated back to the 1950s, with the Homophile groups. See John D'Emilio. Sexual Politics, Sexual Communities: The Making of a Homosexual Minority in the United States, 1940-1970. (Chicago: University of Chicago Press, 1983), 105 \& 235-237. D'Emilio references a specific argument between Daughters of Bilitis founder, Del Martin, and the NACHO convention. As with most of mainstream America, women were often relegated to the work of carrying out the men's agenda while their issues were sidelined in the construction of that agenda; Del Martin's impassioned speech serves as evidence.

12 Rita Mae Brown, A Plain Brown Rapper (Oakland, CA: Diana Press, 1976), 13.
} 
The final years of the sixties and the early years of the seventies were important ones for gays and lesbians. In addition to the political power gained through visibility and activism, these years were the beginnings of a substantial gay and lesbian presence in rural southern Oregon. Gay men from Californian urban centers, such as San Francisco, began to shift their attention to rural community building. In May of 1969, one New Left radical, Carl Wittman, finalized $A$ Gay Manifesto in which he argued, "San Francisco is a refugee camp for homosexuals. We have fled here from every part of the nation, and like refugees elsewhere, we came not because it is so great here, but because it was so bad there." 13 That summer marked the beginning of the Stonewall Inn riots in New York City, a defining moment in lesbian, gay, and transgender history. ${ }^{14}$ Two years later, Carl Wittman and his lover moved from the urban environs of San Francisco to a small piece of rural land outside of Wolf Creek in southern Oregon. By 1974, this land had developed into a mixed gender gay commune called Golden. ${ }^{15}$ A year later, a small group of likeminded friends living in Portland, all in various stages of bisexuality or coming out, purchased 80-acres of land in a canyon outside of Wolf Creek and called it Cabbage Lane. ${ }^{16}$ The following year, a few women purchased WHO Farm in Estacada, Oregon's first lesbian separatist land, an hour outside of Portland. Then, as Zarod Rominski, one of the early residents of Cabbage Lane, so eloquently explained:

\footnotetext{
13 Wittman, Carl. A Gay Manifesto. (1970), republished in Karla Jay and Allen Young eds. Out of the Closets: Voices of Gay Liberation. (New York: Douglas Book Corporation, 1972) 332.

14 The Stonewall Inn Riots are a significant moment in LGBTQ history in that LGBTQ people at the Stonewall Inn stood up and fought back against the NYPD officers who had raided the small Greenwich Village bar they frequented. The bar was raided on the night of June 27 th and the rioting lasted for three days. The LGBTQ community continues to commemorate the events through an annual Pride Parade. ${ }^{15}$ Kopp, 154.

16 Pelican Lee, "NOZAMA TRIBE" in Lesbian Land, Cheney ed., 152.
} 
And so that word spread. And I think that southern Oregon was always, you know--strangely, magically, there were always a lot of women's lands. It's just like all of a sudden--boom! There was OWL Farm. There was Cabbage Lane. There was Rainbow's End. There was Fly Away Home. There was Womanshare. Just boom! boom! boom! boom! boom!--you know, in the course of four or five years! It was kind of astounding. ${ }^{17}$

On the surface, this back-to-the-land movement might not seem political at all, but it was just as engaged in the critique and deconstruction of the status quo as each of the other movements. The people of the back-to-the-land movement came from diverse backgrounds. Bethroot Gwynn, of Fly Away Home, described the atmosphere of her peers in Portland before the move to the land:

Just to say that more and more of my friends, who had been a part of big city liberation politics--at least as big as Portland--were understanding that "I don't want to do this kind of politics anymore." More and more of my friends were understanding that they wanted to be in the country, that they wanted to be close to the natural world, that they wanted to be setting up--creating some kind of alternative model, so it was those kind of values that were beginning to attract attention among my friends. And so I was a part of that evolution. ${ }^{18}$

This movement happened all over the United States, as well as other countries.

Generally speaking, by comparison, on the west coast the back-to-the-land movement more often then not grew out of the counterculture, whereas the east coast trended more toward the B.F. Skinner, Owenite, and Marxist thought. ${ }^{19}$ Although Robert Owen's community of New Harmony, Indiana ultimately failed, his ideas influenced many of the

\footnotetext{
${ }^{17}$ Interview with Zarod Rominski, May 13, 2011, page 36-37.

18 Bethroot Gwynn, interview with author (3 January 2011), 44-45.

19 Timothy Miller, The 60s Communes: Hippies and Beyond. (Syracuse, NY: Syracuse University Press, 1999$) 17$.
} 
communities on the East Coast that formed in the 1960s and later. ${ }^{20}$ The influence of the psychologist B.F. Skinner on the intentional communities of the 1960s and 1970s originated with resurgence in popularity of his 1948 novel, Walden Two, which described a utopian community using work credits to modify behavior. Work credits served as an incentive in lieu of money, with more credits given for jobs that the community considered unpleasant. Virginia's Twin Oaks community has been sited as one successful example of the use of Skinner's ideas in an intentional community. ${ }^{21}$ Twin Oaks, which is still in existence, has had approximately one hundred people living there full time, more than five business ventures that sustain and enrich the community, and is based on an egalitarian philosophy that has little to do with the land or its individual member's sexual, cultural, or political identity. ${ }^{22}$

Unlike Twin Oaks and other egalitarian theory-based communes where process and organization are of utmost importance, the west coast generally and women's land communities specifically valued the place over a particular organizing philosophy. In other words: location, location, location. In his book Eden Within Eden, James Kopp described this quest for location as a "long history of attempts to locate paradise in a physical place."23 Perhaps, Kopp's conceptualization of this division between utopia as place versus state of mind best explains the split between East and West. Some believe they've found utopia. For example, the southern Oregon land lesbians were deeply attached to a specific piece of land, often personified the Earth, and expressed a desire to

\footnotetext{
20 Kopp, 30-31.

${ }^{21}$ Miller, 56.

${ }^{22}$ Kathleen Kinkade, $A$ Walden Two Experiment: The First Five Years of Twin Oaks Community. (New York: William Morrow \& Company, 1973) 31.

${ }^{23}$ Kopp, 13.
} 
protect the land from those who would destroy her. Most of the women described arriving to the land as a spiritual experience, one in which they just "knew" that this is where they were supposed to be. ${ }^{24}$ The lesbian land movement also had little to do with farming or farm labor. While residents of the lesbian lands have made attempted selfsustenance by growing their own vegetables and raising chickens, the lands have never been a profitable or agricultural enterprise..$^{25}$

In Eden Within Eden, James Kopp investigates each individual land or commune as an utopian or intentional community. But it is my contention that the lesbian lands in Southern Oregon were different from other intentional communities in the region. ${ }^{26}$ These lands pool resources and collaborated with one another, as circles of community. These circles started with a single person or single land and grew to encompass a region-Southern Oregon, the West Coast--and out even further into New Mexico, Canada, France, and Germany. Their stories and the growth of lesbian safe space provide evidence of this community and their connections to other lands in the United States and beyond, and that is what I am documenting.

The back-to-the land movement was transnational in scope. There were back-tothe-land pioneers and intentional communities throughout the United States, Canada, Mexico, South America, Japan, Australia, and parts of Europe. Between 1968 and 1975 the back-to-the-land movement in the Pacific Northwest region of North America

\footnotetext{
${ }^{44}$ See Kathleen Kinkade, $A$ Walden Two Experiment: The First Five Tears of Twin Oaks Community (New York: William Morrow \& Company, 1973) or visit <http://www.twinoaks.org > . For references to women's experiences on women's land, see interviews, as well as: Hawk Madrone, Weeding at Dawn: A Lesbian Country Life (Binghamton, NY: Alice Street Editions, Harrington Park Press, 2000), 1-12.

${ }^{25}$ Kleiner, 83-90.

26 See Kopp, 130-145.
} 
reached its peak. ${ }^{27}$ Within Oregon, individuals congregated to form communes in the richly forested areas south of Eugene. Ruth Mountaingrove, one of the founding members of Rootworks, said that in the 1970s, there must have been one hundred communes in Oregon. ${ }^{28}$ Among them were so many lesbian lands, that within the larger American lesbian community the I-5 corridor stretching down in to California and up to Seattle was popularly known as the Amazon Trail. ${ }^{29}$

Between 1972 and 1974 many women from Portland and other cities, moved to the country, most often to live in mixed gender communes. Zarod Rominski remembered living alone in a cabin, and reaching out to others who were searching for a community:

Then it was from there that I began connecting with women who were looking for land, and talking about women's land. I remember one of the first conversations I had about it was with Spes and a woman named Blue-I'm not even sure who that is--And it was just kind of phenomenal, because it was like saying, "You know, I've been thinking that maybe somehow we could get some land just for women." And it was like, "That's what we've been thinking!" We were like, "Wow! Far out!" So there was kind of like this wonderful synergy and magic and it felt like it was meant to be! You know? Sprouting up all around us! And indeed, one of the first pieces of women's land that I visited or--there wasn't any, but Musawa and I--and there were others, but I think this visit was Musawa and I. We went to look at We'Moon farm [WHO Farm], and talked about "was this a possible place that could be women's land?" We talked about that and indeed she bought that land, and it has been women's land ever since. ${ }^{30}$

\footnotetext{
27 Of course this is referencing the second back-to-the-land movement, the first recognizable back-to-theland movement came at the end of WWI with returning soldiers. These dates are primarily based on the creation of new communities and new land purchases, and fail to differentiate between types of communities. In other words these are only based on a number, and without regard to race, age, marital status, religious v. non-religious, gender or sexual identity, or any other mitigating factor. See Kopp, 122 , and 137-141. Also see Sharon Weaver, "First Encounters: 1970s Back-to-the-land Cape Breton, NS and Denman Hornby and Lasqueti Islands, BC," Oral History Forum d'histoire orale 30 (2010): 4.

${ }^{28}$ University of Oregon Special Collections, Ruth Mountaingrove Autobiography Videotapes, Tape 6. See also: Miller, 67.

${ }^{29}$ Kopp, 155.

30 Zarod Rominski, interview with author (13 May 2011), 20.
} 
The 1973 purchase of WHO Farm initiated a split between the back-to-the-land and women's land movements in Oregon. Cabbage Lane established itself in 1972, a year before WHO Farm, but did not become women's land until 1974. The group included at least one openly gay man and other men of varying degrees of bisexuality or stages of coming-out. These 80-acres of canyon forestland near Wolf Creek, Oregon divided along gender lines in the spring of 1974, after most of the men had left the land. ${ }^{31}$ Initially divided by verbal agreement, the lower portion became the women's land called Cabbage Lane, and the upper twenty acres became a men's land called Lilac Ridge. ${ }^{32}$ This is one well-documented example of how a group of like-minded friends slowly separated based upon gender and sexual politics. There are other examples of this separation occurring before the land purchase or without documentation.

Just as the residents of Cabbage Lane and Lilac Ridge lived side-by-side for more than ten years, southern Oregon always retained a separate but connected community of gay men and women. They were able to live on separate lands, and make conscious choices about when and how they interacted. These interactions were often around social events, such as dances and potlucks, or political meetings that were specific to the defense of the area's forestland, attacks that included the Bureau of Land Management's (BLM) timber harvest and mineral extraction policies. ${ }^{33} \mathrm{~A}$ symbiotic relationship between the

\footnotetext{
31 Pelican Lee, "NOZAMA TRIBE," in Lesbian Land, 152-163, ed. Joyce Cheney (Minneapolis: Word Weavers, 1985), 152.

${ }^{32}$ Lilac Ridge is sometimes referred to as Lavender Ridge, within the various newsletters and journal entries.

33 As of 2011, the communes of southern Oregon were still working together against the proposed Liquid Natural Gas pipeline, and the BLM's management of timber sales and other natural resources in the area continue to present issues to the women's land community. In many cases, women's lands are adjacent to BLM lands, and therefore any decisions regarding the use of those resources affect the lives of the members
} 
men's and women's lands remained throughout the seventies and eighties. Around 1990, after the peak of the AIDS epidemic, the subsequent decrease in the gay male population along with the contingency of women who had returned to the cities to confront a growing backlash against the gays and lesbians left the women's lands with a population that was much more committed to the politics of lesbian separatism. ${ }^{34}$ In 1993, the women purchased the men's land, establishing the Cabbage Lane Land Trust, all women's land. ${ }^{35}$

The Cabbage Lane Newsletters and the personal stories of the women involved in the movement place the height of the lesbian land movement in the Pacific Northwest to sometime between 1975 and $1985 .{ }^{36}$ There wasn't a standard pattern to land acquisition and community formation. Some women, such as the women of Cabbage Lane, began their journey within mixed-gender back-to-the-land communes. Other women, like those of Fly Away Home and Steppingwoods, purchased and established lands singly or with their lovers. Some women sought intentional communities comprised exclusively of women, WomanShare being a prime example. All of the women embraced their sexual

of the community. For example, timber sales present situations where men use the same roads and work within close proximity to the lands, which can create an unsafe situation. Also, the clear-cutting or thinning of adjacent lands disrupts the ecology of the entire forest. The effects of which are most acutely felt by those living there (land-slides, water quality, wildlife habitat destruction, etc.). For a specific example, see Ruth Mountaingrove, "Women...Trees..Power," Rough Trade 2 (February 1982): 1-2. Copy found in the The Feminist and Lesbian Periodical Collection, University of Oregon Special Collections, Box 52, Folder 7. 34 Those I have interviewed and other informants have indicated that there has recently been a renewed interest in and development of those relationships, exemplified by some of the younger "queer" identified lands, largely and intentionally undocumented lands, having potluck dinners with the men of Nomenus, a gay men's land.

${ }_{35}$ Community Herstories: Living in Southern Oregon, Tee A. Corinne Papers 1966-2003, Collection 263, Series III Box 1 Folder 32-34, Literary Manuscripts. University of Oregon Special Collections, Eugene, Oregon. See also, SOCLAP!, Collection 266, Box 11, Folder 1. University of Oregon Special Collections, Eugene, Oregon.

36 The Cabbage Lane newsletters can be found in Series II OWL Trust, Box 10, Folders 7-24, SO-CLAP! Collection, Coll 266, Special Collections \& University Archives, University of Oregon, Eugene, Oregon. 
identity as lesbian, their politics as feminist, and had a shared vision of community. ${ }^{37}$ Two women who had previously belonged to Mountain Grove, a hippie commune in Glendale, Oregon, founded Rootworks, another women's land community. ${ }^{38}$ Some women, like those of OWL Farm, a land purchased and created by the southern Oregon women's land community for economically disadvantaged women, had a vision written out in the form of land agreements and bylaws. At times there were residents of OWL Farm who had not participated in the original community meetings regarding the land agreements and bylaws, which on occasion led to resentment. ${ }^{39}$

Over a two-year period I spoke with and collected the oral histories of eight of the elders of the women's land movement in southern Oregon. This movement and community has alternately been referred to as lesbian land or country lesbian, and like the 1970s back-to-the-land movement, it too was transnational in its scope. Women purchased and organized rural land-based communities all over the globe, and women from other communities, in places like Germany and Japan, often travelled to Oregon and vice versa, to learn from one another's experience. ${ }^{40}$ The movement's participants were politically engaged lesbian feminists, part of what we now call second-wave

\footnotetext{
37 Sue, Nelly, Dian, Carol, Billie, Country Lesbians: The Story of the WomanShare Collective (Grants Pass, Oregon: WomanShare Books, 1976), vi-vii.

${ }^{38}$ Jean Mountaingrove, interview with author (23 September 2010), 22.

39 Bethroot Gwynn, interview with author (27 January 2011), 42-46.

40 Among other places, evidence of this cross-cultural exchange can be found within the newsletters and correspondence archived in the So-CLAP collections, and there is photographic evidence in the Ruth Mountaingrove Photograph Collection, Ruth Mountaingrove Papers, Coll 309, Special Collections \& University Archives, University of Oregon Libraries, Eugene, Oregon. Within this collection there are small groupings of photographs showing travel into California and to the Women in Print Conference. There are also international visitors to the land, most notably: the New Zealand women in 1979, the Germans in 1980, and the Japanese in 1981.
} 
feminism, who moved away from urban centers, such as San Francisco and Chicago, and to rural communities to engage in community and culture construction. ${ }^{41}$

The women's land community of southern Oregon attained three main results:

1. They created a safe space in which they could focus on themselves. They learned about themselves as individuals and as a community, and constructed identities.

2. They had an important impact on the development of lesbian culture (history, music, art, spirituality). By providing time, support, and a place for artistic endeavors they were able to create lesbian art, music, and literature, and sent it out to a broader feminist audience.

3. The women who remain on these lands and in this community struggle to keep lesbian land for women. Whether they came for a day, week, month, or even years, since the 1970s women have had land in Oregon, a place to which they could go to look inward, to develop skills, and build community.

Maintaining that land as a women-only space in the face of political change has become a fragile venture at best. The founders of the southern Oregon lesbian land communities are aging, and without a new generation of women to take over the lands there may not be a lesbian land community in the future. At least, there may not be one that reflects the founders' vision of a womyn-only community. In the last two decades separatism has been a less meaningful strategy. Beginning in the 1990s there was a postmodernist-generational shift away from the binaries of gay/straight and male/female identities, and toward what is termed "queer," at times presented as neutral ground, and perceived to be more inclusive of a range of gender and sexual identities.

${ }^{41}$ Or culture reconstruction. It's not like they created a culture out of a new whole cloth. They borrowed, responded, created, and adapted the cultures around them (and the cultures that they had been exposed to). 
Some lesbian feminist separatists who have identified themselves based on gender, sexuality, and politics in opposition to their oppressor, turned that oppression around and sought to reclaim and redefine those identities, see the postmodernist queer model as a rejection of all that they worked so hard to accomplish. Other women see it as an example of how once again the women's movement has been duped and co-opted by men and their need for inclusion. Still others see the humanness of the desire for inclusion, and are willing to participate in the conversation. ${ }^{42}$

The lesbian land movement meaningfully influenced the development of lesbian art and culture. By stepping away from an untenable position, one in which they were on the defensive, to a position of power, they were able to change not only their perception of themselves, but also influence the continued self-perception of lesbians the world over. By understanding the benefit of this strategic shift to lesbian separatism, we can better understand the current trend in queer studies, in which the entire basis for gender and sexual identity is called into question. In other words, these questions of gender and sexual identity, this CR group, began in the 1970s lesbian land movement.

Out of either exhaustion or inspiration, lesbian feminist separatists altered their approach to the political conversation. Rather than asking for permission or protection from men, women demanded a shift in responsibility. For example, previous political engagements were fights for freedom from police harassment, fights for inclusion, struggles against oppression, and struggles against the definitions of medical, legal,

\footnotetext{
42 Elizabeth Weed and Naomi Schor, eds. feminism meets queer theory, (Bloomington,IN: Indiana University Press, 1997), vii - xii. A good example is found editions of A Woman's Place Newsletter, between December 1980 and February 1981 there was a lively debate and discussion regarding the politics of separatism, Box 71, Folder 11, Feminist and Lesbian Periodical Collection, Coll. 257, Special Collections \& University Archives, University of Oregon, Eugene, Oregon.
} 
religious, and psychiatric authority. ${ }^{43}$ At the height of the lesbian land movement, these women opted out of the above actions to redefine themselves and create an exclusively lesbian community and culture. They changed their names, redefined who they were, and wrote and published lesbian herstory. They developed their own art, music, spirituality, literature, and reworked language to better suit their communication needs. They set up workshops to teach others what they had learned and created. They advertised these workshops, concerts, books, and events in their own publications, and taught others how to do the same. Collectively, all of these small things built a culture that redefined what a gay woman was. No longer were lesbians left to believe what popular heterosexual media said about them. No longer were they left to believe that they were sick, immoral, and in need of repair. Following the 1970s, lesbians had a past, present, and future.

This thesis will closely examine the three main results of the Oregon lesbian separatist land community between 1973 and 1985, how those who lived the experience in the communities view those experiences, and the unintended consequences of their ideas and processes. Oral history interviews and community herstories shows how women created a culture and space in which they could recreate themselves, how this culture creation served the wider lesbian culture between 1973 and 1985, and how it impacted a

\footnotetext{
43 In 1973 the American Psychiatric Association's Board of Trustees voted to remove homosexuality from the DSM, the association's manual of mental disorders. Following that vote, a small group of psychiatrists who disagreed with the decision forced the vote to the full membership, which ultimately supported the board's decision. See Eric Marcus, Making Gay History: The Half-Century Fight for Lesbian and Gay Equal Rights, (New York: Perennial, 2002), 122-123 and 181-182.
} 
broader lesbian feminist culture, and informed the current queer politic that eschews the binary understanding of gender and sexual identity. ${ }^{44}$

My primary research sources are oral history interviews with eight women who, in the 1970s, had been instrumental in the development of Oregon's land lesbian community and culture, which still exists today. Oral histories, books, articles, herstories, newsletters, art, and newspaper sources support my research. Those women who were interviewed are educated, politically engaged, white women who identify as lesbian feminists. They came from economic backgrounds that range from working to middle class. Two of the women have adult children. Their careers have included social work, education, community organizing, and the medical field.

All of the activities and movements, such as the New Left, back-to-the-land, gay liberation, and women's liberation, were simultaneous to and included in the experiences of those women interviewed for this thesis, but not all of the women interviewed experienced these activities and movements in the same way. There are some things that some of the women agree on, and there are points on which they disagree. While it's easy and tidy to categorize and generalize this time period and the experiences of this generation, each woman has had her own unique set of experiences along with her own feelings and understandings of them. Oral history deconstructs the tidy layers of historical generalization through individual experience. All of these women shared their understanding of their experience of the development of the lesbian intentional community in southern Oregon, and each is valuable to historical comprehension:

\footnotetext{
44 "herstories" and similar terminology is used in much of the writing by lesbian feminists as a way of reclaiming a language that they feel is male. Therefore his-story becomes her-story, seminar becomes ovular, women becomes womyn or wemyn or wemoon or wimmin, etc.
} 
Jean Mountaingrove, was an original member of Rootworks, and one of the founding editors of WomanSpirit magazine and The Blatant Image: A Magazine of Feminist Photography. As of 2010, Jean moved into the town of Wolf Creek, and served on the board of Rootworks, which is a land trust. Born in 1925, she was eighty-five years of age at the time of her interviews, and revered as one of the community's crones.

As of 2012, Bethroot Gwynn continued to live at Fly Away Home, outside of Myrtle Creek, Oregon, and served as a special editor for We'Moon. Born in 1941, she was sixty-nine at the time of her interviews, and planning a celebratory seventieth birthday weekend on the land.

Hawk Madrone, who purchased Fly Away Home with Bethroot in 1976, also continued to live there at the time of her interviews. Along with Tangren Alexander, Bethroot Gwynn and Jean Mountaingrove, she was active in the Southern Oregon Women Writers' Group, Gourmet Eating Society and Chorus. Alice Street Editions published her book, Weeding at Dawn: A Lesbian Country Life, in 2000. It chronicles her life on the land. Born in 1939, she was seventy-two at the time of interview.

Tangren Alexander, born in 1940, a retired professor of philosophy at Southern Oregon University in Ashland, Oregon, claimed to have only ever experimented with living on women's land, preferring her own space. Our interviews took place in her home in Ashland. She has been considered by many to be a valued member of the larger country lesbian community.

Zarod Rominski left women's land in 1983 to engage in community organizing and social work in the urban environs of Seattle, Washington, and eventually Portland, 
Oregon. In 2012 she was the assistant director of Outside In, and served on the board of the Cabbage Lane Land Trust. She was sixty-eight at the time of her interview.

Jemma Crae moved onto land outside of Roseburg, Oregon in 1975 and called it Steppingwoods. In 2011, she worked as an artist, and hoped to develop a larger community. In the 1980s and into the 1990s she hosted an annual art camp for lesbians called Dyke Art Camp. Born in 1943, she was sixty-seven at the time of her interview.

At the time of her interview, Dana McDonald lived with Jemma at Steppingwoods. Originally from the East Coast, she was born in New York in 1949 and was sixty-one at the time of our interview.

In 2011, Billie Miracle, one the original members of the WomanShare Collective, lived on land adjacent to WomanShare, where she continued her work as an artist and educator at Rogue Community College. WomanShare began as a collective in 1973 by a group of five women, Sue, Nelly, Dian, Carol, and Billie. This group published a book about their experiences, Country Lesbians: The Story of the WomanShare Collective, in 1976. Born in 1944, Billie was sixty-seven at the time of her interview.

The movement to the land, to a commune in some cases was a product of the times--back-to-the-land, New Left, student organizing, anti-Vietnam war demonstrations, women's liberation, hippies, and counterculture. Several narrators made reference to two important figures in their lives, at times crediting them with the existence of several pieces of the women's land puzzle--or quilt, if you will--Barbara and Mark Alter. Like a number of the lesbian feminists living in the women's land community of southern Oregon, Barbara and Mark moved to the country from the city of Portland after actively participation in urban New Left politics. They were so engaged that at one point they 
were under FBI surveillance, and Mark was taken in for questioning and jailed for refusing to cooperate with authorities that were investigating the Weathermen organization. ${ }^{45}$ When Barbara and Mark divorced there was a substantial divorce settlement that Barbara then divided amongst her female friends, and they, in turn, divided it among their friends, as was the 1970s fashion. Many were questioning money, the value of money, sharing money, and separating themselves from class privilege.

Some of those who had been given this money used it to purchase some of the lands that are now women's lands. Some of the money was donated toward the down payment on OWL Farm, the only truly "open" women's land in Oregon, meaning that any woman with commitment and perseverance, could potentially live there. ${ }^{46}$ All of the other lesbian land communities have residential criteria or are invitation only. The purpose of OWL Farm was to provide women who were otherwise financially disadvantaged access to land. ${ }^{47}$ Like most historically communal lands, OWL Farm's idealistic beginnings didn't always come to fruition, but the historical record of their many attempts provide an opportunity to examine a concrete example of a collective lesbian feminist vision.

Many texts inform my work, including those by scholars of utopian communities, social and political movements, and other scholars of lesbian communities. The editors of Women in Spiritual and Communitarian Societies, explained that they could not cover every type of communal experience within one book, and wanted to, "encourage feminist inquiry

45 This was mentioned by a couple of different informants, and was verified with a cursory search of the media at the time. For example, see the AP article published in the Oregonian. "Oregon man jailed in probe," Oregonian, January 20, 1973, Section 4M, 12.

${ }^{46}$ Originally, OWL Farm was established to address the accessibility issue

47 This is a paraphrasing of one of the Oregon Women's Land Trust's Articles of Incorporation, which were reprinted in WomanSpirit 11, 1977, and reprinted in Community Herstories -not pink-page 27; from Lesbian Land, Cheney ed. "NOZAMA TRIBE" by Pelican Lee, p. 158 
that would examine in greater depth the boundaries and limitations of community itself. In other words, what is a feminist definition of community?"48 Not only does this thesis closely examine the definitions of community offered by narrators, it also addresses the deeper concerns of community goals and accomplishments. What did the lesbian land communities of southern Oregon set out to accomplish? And to what degree did they succeed?

For six months in 1992, LaVerne Gagehabib and Barbara Summerhawk conducted well over fifty interviews with women in the lesbian land community of southern Oregon, and published a synthesis of their participant-observer study in 2000. Barbara Summerhawk's description of their monograph, Circles of Power: Shifting Dynamics in a Lesbian-Centered Community, is that it is a "contribution to the study of identity, community formation, and lesbian herstory." 49 Much of the book's focus a sociological examination of race, class, power, community relationships, and ownership. Considering the political events of the time in which they undertook this study, the "No on 9" campaign and subsequent anti-gay violence is central to and a significant influence on this work. Ballot Measure 9 was an initiative sponsored by Lon Mabon's far right fundamentalist group, Oregon Citizen's Alliance (OCA). The initiative equated homosexuality with pedophilia and necrophilia, and would have prevented any state agency from recognizing sexual orientation or sexual preference as a category deserving of protection. In other words, the 1992 ballot measure would have undone all of the

\footnotetext{
${ }^{48}$ Marlyn Klee-Hartzell, "Introduction," in Women in Spiritual and Communitarian Societies in the United States, ed. Wendy E. Chmielewski, Louis J. Kern and Marlyn Klee-Hartzell (NY: Syracuse University Press, 1993$), 8$. ${ }^{49}$ La Verne Gagehabib and Barbara Summerhawk, Circles of Power: Shifting Dynamics in a Lesbian-centered Community (Norwich, VT: New Victoria Publishers, 2000), 9.
} 
progress made by Oregon's gay and lesbian activists and their allies. ${ }^{50}$ Where Gagehabib and Summerhawk succeed at placing the lands within the history of state and local politics, and exams their process of political engagement, this thesis attends to the cultural engagement and material outcomes.

Similarly, Catherine Kleiner's 2003 doctoral thesis, Doin' It For Themselves: Lesbian Land Communities in Southern Oregon, 1970-1995, examined the lesbian land communities of southern Oregon with a focus on "lesbian identity and the lesbian land movement, the development of land-based communities, and the evolution of a distinctive land-based lesbian separatist culture." ${ }^{51}$ Catherine B. Kleiner's work is instrumental in establishing the outlines of six of the more prominent lands within southern Oregon, and a close examination of lesbian identity and the development of lesbian spirituality within these communities. Kleiner convincingly showed how this community adopted spiritual practices that were the predecessor to the ecofeminist practices and philosophies popularized in the late 1980s and early 1990s by thinkers and writers such as Greta Gaard, Diana Fuss, Val Plumwood, and Vandana Shiva. She accurately reported that the land lesbians of Southern Oregon did not consider themselves ecofeminists, and most would not now identify with that terminology. Kleiner contended that, "Land lesbians associate ecofeminism with 'overly intellectualized' academic theorists who know little about real women in land communities." ${ }^{52}$ She also detailed the practical dilemmas of rural communal living. This thesis complements hers by presenting a closer examination the creative endeavors of the community and their impact on the wider lesbian culture.

\footnotetext{
${ }^{50}$ See Gagehabib and Summerhawk, 86-87 and Appendix D.

${ }^{51}$ Catherine B. Kleiner, Doin' It For Themselves: Lesbian Land Communities in Oregon, 1970-1995 (PhD. Diss. University of New Mexico, 2004), viii.

52 Kleiner, 94.
} 
Where Kleiner focuses more attention on the spiritual relationships and cultural construction, this thesis attends to the media and media networks that carried the materials out to the wider U.S. lesbian community, and carried in and integrated influences from other parts of the world.

However, Kleiner's interviews were not archived. Because the interviews were not always recorded, and were not archived there is no way to verify her information, and subsequent oral history interviews with some of the same narrators reveal substantial factual inaccuracies, (including which lands were held communally, the locations of events, historical chronology, and in some cases self-identifying terminology). Like Kleiner, Barbara Summerhawk and LaVerne Gagehabib also did not record or archive the interviews they used for their book. Although, some of the details of the formation of women's lands and the lives of these women are documented within the University of Oregon's archives, So-CLAP! (Southern Oregon Country Lesbian Archival Project), the only remnant of their interviews is within the text. ${ }^{53}$

James Kopp's phenomenal 2009 book, Eden Within Eden: Oregon's Utopian Heritage, provides an excellent source manual for materials related to Oregon's long history of intentional communities. However, his 180-page overview of this history relies too heavily on previously published materials that in some cases are wrong. For example, he described the Family of the Mystic Arts, which was a countercultural commune started by a small group of hippies from San Francisco, as a religious commune, quoting from an editor of the Commune Directory put out by Alternatives magazine that they "were devout

\footnotetext{
53 The University of Oregon Special Collections Library holds the Southern Oregon Country Lesbian Archival Project (So-CLAP!) and the Lesbian and Feminist Periodical Collection, most of which was donated by Ruth and Jean Mountaingrove, Tee Corinne, and Bethroot Gwynn.
} 
fundamentalists [sic] Christians--believers in the Literal words of the Bible." 54 Kopp repeated an error that he could have corrected by contacting the Family directly, some of whom live in Portland and others who still live on land outside of Sunny Valley, Oregon. My neighbor, one of the children who grew up in the Family of the Mystic Arts commune, explained to me how this particular error is an example of how communities purposefully sent out false and misleading information, because they didn't want people to find them, a practice that is still prevalent today. Our conversation illustrates the importance of a critical examination of all of the evidence. Errors such as this highlight the importance of oral history, and the documentation, archiving, and accessibility of those oral histories.

For a historian, the opportunity to literally interrogate the source is irresistible. However, as with most sources, even the living, breathing and talking human variety, more often than not, produce more questions than answers. The initial objective for this collection of interviews was twofold. First, I wanted to begin a biographical life story collection of interviews with women who had been participants in the women's land movement of the 1970s, a project that could be continued by other scholars. Secondly, I wanted to begin with those who were the elders, women who were historically significant to the community. To accomplish these objectives, I used open-ended chronological questions, and allowed the narrator to direct the interview as much as possible. Each interview contained the question, "What do you think is important for younger women to know and understand about your history and the history of lesbians of your generation?"

${ }^{54}$ Kopp, 136. 
and concluded with "Is there anything else that you'd like to share?" In the end, the narrator's story guided the interviews.

My method for identifying potential narrators began in the archives at the University of Oregon Special Collections Library. The University of Oregon holds the Southern Oregon Country Lesbian Archival Project (SOCLAP!) and the Lesbian and Feminist Periodical Collection, most of which was donated by Jean Mountaingrove, the oldest living community member and a respected elder. After perusing the contents of those collections, I had a wish list of about twenty people. An acquaintance that had just recently moved onto land outside of Sunny Valley, Oregon, introduced me to Jean Mountaingrove. After an initial meeting and first interview with her, I slowly earned community trust, and was introduced to a couple other women on my wish list. The interviews then all proceeded in a similar manner, with each leading to the next contact and potential narrator, commonly known as the "snowball method."

One unanticipated factor affected my entire process. The physical safety and survival of lesbian separatist feminists in southern Oregon in the 1970s required a certain amount of secrecy and discretion. Then the sometimes violent backlash that following the 1992 "No on 9" campaign simply reinforced the logic of that survival strategy. ${ }^{55}$ Not all of these lands are publicized. Some women's land communities choose to remain unpublicized. Most of them do not reveal their locations until a certain level of trust is established, and the same can be said for the women who have lived or continue to live within these communities. Therefore, I had no idea how many lands there were before I began interviewing, and could not anticipate how large the scope of this project would

${ }^{5}$ See Gagehabib and Summerhawk, 86-87 and also Heather Lyn MacDonald's documentary film, Ballot Measure 9 (2008). 
grow. For every interview recorded there were at least six other people who were not interviewed. Moreover, as oral historians, Susan H. Armitage and Sherna Berger Gluck pointed out narrators are limited to those confident enough to answer emails or return phone calls. My interviews were limited to those who were confident they could give me the story that they thought I wanted to hear. ${ }^{56}$ That being said, these women have stories that document and decipher an important piece of Oregon history, women's history, gay and lesbian history, political movement history, and the interviews significantly add to the existing historical record.

When I presented my work in progress at a public venue in Portland, I made connections with women in the city, who have had either a physical presence or deep connection to the community. Having gained the trust and respect of this group of women, perhaps I have opened up a space for future scholarship and historic preservation.

Unlike the study of the United States in the eighteenth or nineteenth century, the study and preservation of history within memory presents its own set of issues relating to narrator expectations. How do you get the story right? Where is the line between the story told by the narrators and the story interpreted by the historian? There is a responsibility to the narrator, who has given both time and trust, as well as to the practice of history, in which critical examination of the evidence is key. How does an oral historian balance the two? ${ }^{57}$ Although I don't have all of the answers to these questions, I

\footnotetext{
56 Susan H. Armitage and Sherna Berger Gluck, "Reflections on Women's Oral History: An Exchange," in Women's Oral History: the Frontier Reader, ed. Susan H. Armitage with Patricia Hart and Karen Weathermon (Lincoln: University of Nebraska Press, 2002), 82-83.

57 These are questions that are faced by all oral historians. Some good essays about this subject can be found in Part III of Robert Perks and Alistair Thomson, eds., The Oral History Reader, Second Edition (New York: Routledge, 2006), 211 - 332.
} 
do know that it's important to show all of your cards to the reader. As a forty-year-old lesbian I had a privileged view of a community that would have been denied me had I been a heterosexual male. All of the women I interviewed were older than me, at an age equivalent to that of either my mother or grandmother, and that age difference affected the way I conducted the interview and the way that they responded. There is no way around that. On the one hand, this relationship served as an asset, sometimes the woman I was interviewing felt comfortable enough to reveal parts of her past and her interior life that she might not have otherwise. On the other hand, this relationship was a burden, because at times I found myself uncomfortable asking some of the harder questions or perhaps I was too respectful and failed to pursue a particular line of questioning. Even more simply, I may have failed to ask the easy questions, because I may have thought that I already had the answers. I have tried to view the material in conjunction with printed materials to get as accurate a picture of the past as possible.

It is true that there was never a diverse population of lesbians living on the lands; most were educated white women from working and middle class backgrounds. ${ }^{58}$ However, these innovative lesbian communities did create a safe space for lesbian feminists to find a respite from the difficult task of changing the world, and an opportunity to focus their attention and energy on themselves. This time and space allowed for the development and experimentation with new ways of being, and new ways of being in community with one another and the outside world. This creation and maintenance of safe lesbian space is a continuation of what was created in urban settings,

\footnotetext{
58 Scott Herring. "Out of the Closets, Into the Woods: RFD, Country Women, and the Post-Stonewall Emergence of Queer Anti-urbanism.” American Quarterly 59, no. 2 (2007), 348. See also Sue, Nelly, Dian, Carol, Billie, vi-vii.
} 
in the form of bars, but on a much larger scale. This was important, because it created and nurtured women's ability to see both in themselves and in the world, the change they wanted to realize.

Before addressing the various components that constitute the development of lesbian culture, as addressed by the counterculture of the southern Oregon lesbian land communities, the general terms of this thesis need definition. Most importantly, the designation of these communities as "southern Oregon lesbian land" ought to be defined both geographically and ideologically. Geographically the lands tend to cluster in rural areas off of the I-5 corridor. These areas are dense forestlands, consisting of Douglas fir, ponderosa pine, cedar, madrone, oaks, chinquapins and other trees. Most of the lands are in mountainous areas. Some of them are on incredibly steep inclines, some in deep valleys in which sunlight rarely reaches through the forest canopy, and some atop mountain ridges, which afford breathtaking views.

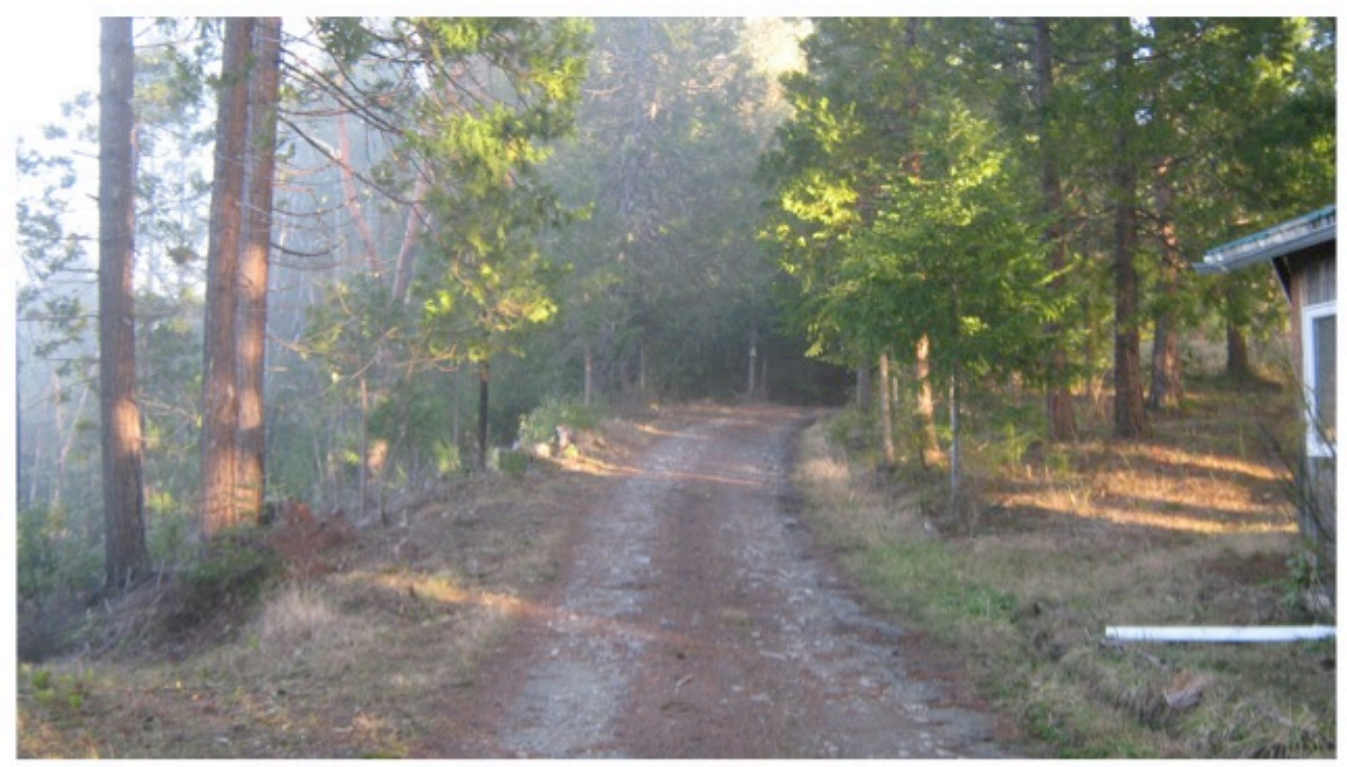

Figure 1: Fly Away Home 2011, photo by author. 
Many of the lesbian lands have had adjacent neighbors, and most of the uninhabited adjacent lands are owned and managed by the Federal Bureau of Land Management (BLM), and are subject to logging and mining. The land that is furthest north is We'Moon Land, about five miles from Estacada, Oregon. The southernmost Oregon lesbian land is WomanShare Collective, located in southern Josephine County among a small cluster of adjoining and neighboring lesbian lands.

Ideologically, the southern Oregon lesbian lands are lesbian feminist separatists with roots in the 1970s back-to-the-land movement. All of the lands practice varying degrees of lesbian separatism, stemming from the belief that the removal of oneself from the dysfunctional patriarchal society that men created is a political and healing act. For some individual women this political practice has changed over the course of the last thirty years, but others have held fast to their conviction. Hawk Madrone of Fly Away Home explained this theory best by saying:

The more and more I got involved with women's liberation, and what was called gay women's liberation, the less and less I wanted to be involved with the world that men have made. I wanted to create a world that celebrated, honored, and was true to, what was for me, the spirit of women, and that was not the world of patriarchy. So I wanted to create a life as free from the world that men have made as possible, and at the same time I am drawn to living on land. So creating land, we're creating a home to which only women would come. That was the dream. It was sort of a natural progression, you know, it was a--I didn't wake up one morning and decide, 'Okay, I'm going to be a separatist.' It sort of, you know, the more free I became in loving women, as opposed to my own little relationship with this one particular person, the larger that that got, loving women, you know, en masse, then it just naturally progressed to--of course, that's where I want to put all of my focus. That's where I want to put all of my physical, mental, emotional, financial--if I have any, energy--political energy, spiritual energy. 
That's where I want to put it all. I don't want to put it out there anymore. ${ }^{59}$

On one end of the spectrum some lands hold women-only functions, but allow male visitors. To the other extreme there are lands that only welcome women, and try, to the best of their ability, to expend energy, money, and time only on women. Tangren Alexander explained this need for women-only spaces:

Once we didn't have men, so we didn't have any of the dealing with our own reaction, our own taking care of them, our own whatever it is that we do-without that pressure at all--we could see where we could go. I think it freed up all kinds of creativity, in ways of relating and in ways of doing things. So to me, it was about having fun (laughs), and getting lots of encouragement from other women and encouraging them, you know, that kind of stuff. It was not about victimhood. ${ }^{60}$

The politics and practice of lesbian separatism was at its height during the construction of lesbian land culture, and shaped the community landscape, culture, and cultural material. While many women within the community could detail the ways in which they had been personally harmed by both men and patriarchy, women do not view this as an exclusive motivation for community development or separatist choices. What Tangren sheds the most light on is the need for women-only space, so that women could relieve themselves of their own complicity with their oppression.

The idea of community needs further definition. Community is a word that is used widely in the social sciences to describe many types of groupings of people. While many of the women of the southern Oregon lesbian land community lived on separate

${ }^{59}$ Hawk Madrone, interview with author (28 January 2011), 42-43.

60 Tangren Alexander, interview with author, (13 February 2011): 21. 
lands with different specificities and often separated by miles, they considered themselves to be a part of a greater community that extended beyond state and national borders. Perhaps the best definition for "community" is presented by Bethroot Gwynn of Fly Away Home:

We've always said, "Okay, women's lands are those lands where women are living, and the land is devoted to serving not only the women who live there." --so women visitors are welcome. There are sometimes events, workshops, ceremonies---that's been one of my definitions, so the women who choose to be, the lands that are listed on that women's land flyer are the ones that welcome visitors. I've also had an additional definition, and I don't know whether it flies or not, but there are lands whose founders imagined that this will continue to be women's land after I am personally gone. That's my hope. ${ }^{61}$

In other words, there are a variety of women who have stayed for varying lengths of time who are still counted a part of the community if they choose to be. These women still connect with each other through newsletters of the individual lands and The Womyn's Grapevine Newesletter. ${ }^{62}$ The community also includes the land among its membership. The land is integral, perhaps as important as the women themselves. The community also embraces visitors as, with many women staying for lengthy and repeated visits.

Similarly, Barbara Summerhawk defined the southern Oregon women's community as "that group of women who are living or have lived in Southern Oregon between Eugene and the California border. These women consider or have considered themselves part of a group of roughly three hundred to four hundred women who identify

${ }^{61}$ Bethroot Gwynn, interview with author, (27 January 2011), 47.

${ }^{62}$ Older versions of this newsletter can be found: The Womyn's Grapevine Newsletter, Series XIII: Networking Materials, Box 17 Folders 20-26, So-CLAP! Collection, Coll 266, Special Collections \& University Archive, University of Oregon, Eugene, Oregon. 
as the Southern Oregon Women's Community."63 The important thing to note is that this is a self-identifying group. There may be other women who appear to meet some or all criteria for inclusion, but do not identify themselves as a part of the community.

Each woman's experience of community is also unique. While some women, like Bethroot and Madrone were aware of other intentional lesbian land communities, others were not. Jemma Crae initially purchased Steppingwoods with JP, a woman with whom she was intimately involved, and only later realized that there were other lesbians and groups of lesbians who were also purchasing land and building homes in the area:

It was about 1976 that we had some hippie neighbors. We really liked them. They had this spring fair--that was like second year of the spring fair. J.P. and I went. While we were there we saw two other lesbians, and one of them turned around and said, "There's some lesbians!" And I said, "J.P. we have to meet these women." And she said, "Okay." We looked around. We saw a couple more lesbians, and we thought, "Oh my gosh! Here's our community!" (HB laughs) I was getting really excited, so J.P. went up to Bethroot and said, "Gee don't I know you from somewhere?" And Bethroot said, "No, but you should!" (HB laughs) We started talking. Bethroot lived without electricity.

Then Francis was there and she came up and she said, "We live at Rainbow's End." We discovered it was only five miles away. We said, "Oh my gosh! We've got to get to know each other!" So I went up to Thwing, who was our neighbor, our hippie neighbor and I said "Thwing! Thwing! We found our community!" (HB laughs) And that was one of the highlights of my life. I mean, the happiest moments of my life was finding a community. We were all doing the same thing, and we didn't know it. ${ }^{64}$

Similarly there are and have been women who live in Ashland and other towns who visited the lands regularly, attended workshops, circles, or other community functions, and are an integral part of the community. Therefore, for the purpose of this

${ }^{63}$ Gagehabib, 15.

${ }^{64}$ Jemma Crae, interview with author, (13 January 2011): 13-14. 
text, the community includes the land itself, as well as any woman who self-identifies with the land and those who live there.

Each chapter of this thesis serves to evaluate the construction of a community of like-minded women using the analysis of oral histories and other "self-reflective" and "selfcreated" materials. I begin by exploring the place, the land, the space that women purchased, constructed, inhabited, created, and charged with meaning. Through an examination of the oral histories, autobiographical materials, and the creative endeavors of the women of the women's land community, a deeper understanding of the personal significance of this space is achieved. Moreover, what is done in the space and with the land, the subject of the third chapter, positions the women's land community within the wider community, which stretches out beyond both the Pacific Northwest region of the United States and beyond the 1970s, impacting the present. The fourth chapter examines how the population and purpose of the southern Oregon lesbian lands has changed over time, and how the founders and remaining elders see the future of women's land in Oregon. The concluding chapter draws upon all of the evidence to come to understand how this had impacted the present, and the unintentional consequences of the lesbian land activities. 


\section{Chapter 2: A Safe Space to Become}

It's on land. It's safety. It's enough far away from everybody else that you really can, you know, not wear a shirt if you don't want to or walk around in nothing but your boots and do your gardening. And you can sing. If you needed to you could go out on the land and sob your heart out. I mean you can just-there's a freedom there that just isn't anywhere else. And so even those of us that don't live on land, at least for me--I find it very precious that the land is there. It really feels, when I go to Fly Away Home, like I've left the United States of America. I'm somewhere else. I'm in another world where we do things differently, and where different rules apply.

--Tangren Alexander 65

Madeline D. Davis and Elizabeth Lapovsky Kennedy's oral history study, Boots of Leather, Slippers of Gold: The History of a Lesbian Community, placed the lesbian bar culture of the 1930s-1960s into the larger context of Gay and Women's history, and explored the development and defense of safe lesbian space. Over the course of fourteen years Kennedy and Davis, with the help of several other women through the Buffalo Women's Oral History Project, collected oral histories from 45 working-class lesbians who had been involved in the pre-1970 lesbian bar culture of Buffalo, New York. ${ }^{66}$ The collection examined the creation and maintenance of safe lesbian space in the form of bars and house parties. Prior to 1970, most gay and lesbian bars were not established as such, but simply bars whose owners tolerated a homosexual presence, and recognized it as an acceptable business risk. These safe spaces were established and protected by their

65 Tangren Alexander, interview with author, (12 November 2010): 20.

${ }^{66}$ Kennedy and Davis, xvi-16. 
clientele, with butches sometimes physically fighting heterosexual men to maintain this safe space for gay women. ${ }^{67}$

That butches and fems made choices that enabled the establishment or takeover of bars for lesbian community activity is in itself significant. It is also a pre-cursor to the development of the 1970 s lesbian land communities. ${ }^{68}$ The choices and risks lesbians took for the establishment and defense of safe lesbian space in bars carried over into rural lesbian land communities, including those in southern Oregon. Portland, the largest city in Oregon, also maintained a lively pre-1970 bar culture, and like the Buffalo lesbian community, had to protect it to maintain it. ${ }^{69}$ The Music Hall was a known gay and lesbian entertainment center, which hosted vaudeville acts with both male and female impersonators, and was often a target of local politicians and police. ${ }^{70}$ This early lesbian community also congregated in house parties and by 1974, a year after the American Psychiatric Board's removal of homosexuality from the manual of officially recognized mental disorders, extended out to sporting events, community organizations, businesses, and bookstores. ${ }^{71}$

\footnotetext{
67 Kennedy and Davis make reference to this throughout the book, examples can be found in Chapter 3, 67-1 12. This type of physical defense of lesbian bars is also noted in Roey Thorpe, "The Changing Face of Lesbian Bars in Detroit, 1938-1965," in Creating a Place for Ourselves: Lesbian, Gay, and Bisexual Community Histories, ed. Brett Beemyn (New York: Routledge, 1997), 168-171.

68 Elizabeth Lapovsky Kennedy and Madeline D. Davis. Boots of Leather, Slippers of Gold: The History of a Lesbian Community. (New York: Routledge, 1993): 31 and 373-377.

${ }^{69}$ For example see Tom Cook (revised by George Painter), 1999 Portland Gay History Walking Tour, http://www.glapn.org/6045walkingtour.html. See also, Peter Boag, "'Does Portland Need a Homophile Society?': Gay Culture and Activism in the Rose City between World War II and Stonewall," Oregon Historical Quarterly 105, no. 1 (2004): 13.

70 Ibid. See also June Thomas, "The Gay Bar: Why the gay rights movement was born in one," Slate Magazine, http://www.slate.com/articles/life/the_gay_bar/2011/06/the_gay_bar_4.html

${ }^{71}$ For example, A Woman's Place, Portland's first feminist bookstore was started in 1973 and by 1975 was publishing its own newsletter (A Woman's Place Newsletter, Portland, OR, 1975-1979, Box 71, folder 4, Feminist and Lesbian Periodical Collection, Coll. 257, Special Collections \& University Archives, University of Oregon, Eugene, Oregon 97403-1299.), which informed the burgeoning lesbian and feminist community of events and gatherings.
} 
The need for safety within American gay and lesbian culture throughout its history is well documented..$^{72}$ In 2008, Christina B. Hanhardt wrote a compelling article examining the emergence of LGBT anti-violence and protection groups within emerging LGBT neighborhoods in major U.S. cities, explaining that street patrols were "a means by which geographic spaces were claimed as gay territories."73 While the 1970s was a time in which gays and lesbians had a visible presence, that presence did not come without a cost. The gay men and women within large cities often faced violent consequences for the merely appearing "queer" in the wrong neighborhood. ${ }^{74}$ This demand for safety and organized territorial claim within gay neighborhoods in American cities corresponded with the emergence of similar protective claims in rural communities.

The recorded oral histories of women living on lesbian land in southern Oregon in the 1970s and 1980s indicate that land lesbians also recognized the importance of safe space. In a 2012 Cabbage Lane Herstory Circle at Zarod Rominski’s home women spoke to the question of what the land meant to them, and the women connected the place of Cabbage Lane with feelings of safety and community. Nelly Kaufer said that Cabbage Lane was imagined as a gay commune even though at the time not all of them identified as gay. They saw it as a place to overcome their fears, a place away from men and the city. Susanna claimed that at Cabbage Lane she felt "safe from the outside world of men." Musawa also described Cabbage Lane as a "Natural Lesbian Forest" and "safe

\footnotetext{
${ }^{72}$ Examples can be found throughout the work of LGBTQ history scholars, and include: Esther Newton, Cherry Grove, Fire Island: Sixty Years in America's First Gay and Lesbian Town, (Boston: Beacon Press, 1993), Nan Alamilla Boyd, Wide-Open Town: A history of queer San Francisco to 1965, (Berkeley: University of California Press, 2003), Brett Beemyn, ed., Creating A Place For Ourselves: Lesbian, Gay, and Bisexual Community Histories, (New York: Routledge, 1997), and John Howard, Men Like That: A Southern Queer History, Chicago: University of Chicago Press, 1999).

${ }^{73}$ Christina B Hanhardt, "Butterflies, Whistles, and Fists: Gay Safe Street Patrols and the New Gay Ghetto, 1976-1981," Radical History Review 100 (Winter 2008), 74.

${ }^{74}$ There are many published accounts of this violence. For example see Marcus, 203.
} 
women's land." In 1976, Comfrey felt the same about Golden, a gay commune near Cabbage Lane. She saw it as a personal and physical claim to independence and safety. ${ }^{75}$ Victoria, the most recent Cabbage Lane resident, said that going to Cabbage Lane for the first time in 2008 was like "returning to a home I've never been to before."76

The interviews with early founding members of these lesbian land communities in southern Oregon contain stories of past experiences within urban environments, which can be interpreted as critical to their understanding of the safety of women in general, and lesbians or gay women, in particular. All of the women interviewed saw a mainstream American society in which women were undervalued, underpaid, and under attack. For gay women this was doubly so. There were still public institutions, such as the church, state, and psychiatry that defined lesbian identity as a sickness. For churches it was a moral sickness. Laws defined their sexual behavior as illegal, thereby stigmatizing those claiming the sexual identity, and many in psychiatry remained convinced that it was a curable illness until well after $1973 .{ }^{77}$ The connection between lesbianism and illness was so strong in the 1970s that Bethroot Gwynn remembered that those closest to her were

\footnotetext{
75 All of the Cabbage Lane Herstory Circle materials were recorded by land women with the intention of eventually transcribing and archiving the circles (as there were four throughout Oregon) at the University of Oregon, in the SOCLAP! collection. The Cabbage Lane Herstory Circles that is referenced here was organized by Zarod Rominski in February 2012 with the intention of providing the newest members of the commune with a connection to the past. The materials herein are from my field notes and personal recording.

76 Victoria was one of three women living at Cabbage Lane in 2012. Her and her partner Kim have been working to restore the community.

77 See "Homosexual employment bill defeated." Oregonian. April 22, 1975, A1. The article discusses the legal and voter opposition to protecting homosexuals in the area housing and employment discrimination. See also, Pandora, (June 1975), 10. (Special Collections, University of Oregon Libraries, Coll. 257. Jean and Ruth Mountaingrove, Feminist and Lesbian Periodical Collection. 1932-1997. Box 46a, Folder 1). The issue discusses the controversy over lesbians in feminist organizations, and how some feminists fear that the visibility of lesbians within an organization harms the feminist cause. Similarly, homosexuality wasn't removed from the DSM as pathology until 1973.
} 
advised to not appear in court during her 1976 psychotic break, because any association with women who appeared lesbian could hurt her mental competency hearing. ${ }^{78}$

There were many other public institutions and public venues in which lesbian association or lesbian visibility was avoided out of a fear of detrimental consequences. Gay women lived with the fear that having one's sexuality revealed to the wrong person could result in the loss of one's job or home. This discrimination was in addition to the discrimination that they were already working against in the women's liberation movement. ${ }^{79}$ For example, Madrone recalled being "de-hired" after teaching a non-credit class entitled "Lesbianism: Sickness or Revolution?" at Merritt College in Oakland, California, and claimed that the reason for not being rehired, although unspoken, was that some faculty did not like having lesbians associated with the college..$^{80}$

In addition to the dangers and discrimination faced by lesbians of this time period in urban environments, rural southern Oregon held its own challenges and threats. This part of the state had been colonized in the late nineteenth and early twentieth century by miners, farmers, lumberjacks, and millworkers. By the late 1960s, many of the residents of small southern Oregon towns, such as Grants Pass and Roseburg were actively resisting what they saw as an invasion of hippies. The small towns and families of rural Josephine County and other areas were employing regular sanitation inspections and reporting building code violations in an effort to intimidate and monitor the back-to-the-land

\footnotetext{
78 Bethroot Gwynn, interview with author (27 January 2011): 17-19.

${ }^{79}$ Examples of which can be found throughout the oral histories of the lesbian land women I interviewed, as well as the University of Oregon's Feminist and Lesbian Periodical Collection. See, for example, Tee Corinne's collection of lesbian land writings in Community Herstories: Living in Southern Oregon. Many of the women who submitted writing to Tee for this herstory repeatedly note that in the early 1970 s women were searching for land. They were holding meetings to discuss the possibilities in Eugene, Salem, and Portland. Some have suggested that it was out of these meetings that the idea for OWL farm originated. Others claim that it came out of a workshop on race and class that was held at WomanShare.

${ }^{80}$ Hawk Madrone, interview with author (28 January 2011): 22-23.
} 
communes. ${ }^{81}$ In 1969 Takilma resident Floyd Rice told an Oregonian reporter: "There are people in Grants Pass who won't serve them, won't let them go into the movie houses."'82 Many businesses placed signs in their windows advertising their denial of services to hippies. ${ }^{83}$ The local populations around places like Roseburg, Wolf Creek, Sunny Valley, and Grants Pass included people whose families had lived in this area for generations and tended to associate hippies with drug use, nudity, and crime. ${ }^{84}$

The subsequent influx of gay and lesbian communes only added to an already volatile situation. The most memorable for many of the women interviewed was the firebombing of Creekland, a gay men's commune outside of Wolf Creek. Contemporary newspaper reports of the crime blamed the flamboyant behavior of the gay men for the firebombing, citing examples of well-behaved or secretive gay and lesbian communes in contrast to Creekland. One Oregonian article even used quotes from gay male members of other gay communes as thinly veiled accusations, implying that the men of Creekland asked for it because of the way they dressed. ${ }^{85}$

Throughout much of the history of Rainbow's End, an Oregon women's land outside of the city of Roseburg, residents experienced the regular harassment of an unfriendly neighbor. Those interviewed have described the harassment as ranging from unfriendly looks as they drove onto the land via a shared road to constantly filing

\footnotetext{
${ }^{81}$ Bob Olmos, "Conflict in The Valley of The 'Wasps'," The Sunday Oregonian. April 27, 1969, 169.

82 Bob Olmos, 169.

83 Olmos, 169.

84 This is evident throughout the Oregonian and other newspapers between 1967 and 1974. For example see the Sunday Oregonian. August 24, 1969: 115.

85 See two articles: "Gay Commune gets attention of unwanted sort" and " 'Redneck' community home of new lifestyles" in the Oregonian, July 22, 1979: B1.
} 
complaints with government officials resulting in a lack of privacy. ${ }^{86}$ Jemma Crae, who lives on Steppingwoods, which is also outside of Roseburg, explained that early on in the movement, they tried to stay away from Roseburg, because it was known as a Klan town. Jemma said, "While I was at Lewis and Clark, I heard about Roseburg. Roseburg had a sundown law until the sixties or later--maybe later, and that meant that black people couldn't spend the night there."87

However, by 1971, lands around Eugene, had become scarce and expensive, so women had to look further south. Roseburg was more reasonably priced, and the plots were larger. ${ }^{88}$ By the early 1980 s, there was a thriving lesbian and gay community in Roseburg, including a community center and switchboard, but it still wasn't easy. According to Jemma:

It was difficult in this town, because they wouldn't even put our phone number in the paper. It was hard. We put up flyers for our switchboard, and people would tear them down. They just didn't want to see that there were homosexuals in Roseburg, and of course, we're everywhere. ${ }^{89}$

\footnotetext{
86 See Hawk Madrone, (interviewed by author 28 January 2011): 36. See also Francis (Eatherington) Star, "How I came to Rainbow's End..." in Community Herstories: Living in Southern Oregon. compiled by Tee A. Corinne (ca. 1990), Tee A. Corinne Papers, Coll. 263, Special Collections \& University Archives, University of Oregon, Eugene, Oregon

${ }^{87}$ Jemma Crae, interview by author (13 January 2011): 11. While no evidence of these "sundown laws" on the books exists, they are evident in oral histories, and they are documented and written about in texts, including James W. Loewen, Sundown Towns: A Hidden Dimension of American Racism (New York: WWNorton, 2005). Also in 1953 Oregon passed the first Public Accommodations Law, which was intended to prevent discrimination in public accommodations, but did not change discriminatory practices in real estate or private accommodations. All evidence suggests that these "sundown laws" were used to intimidate and frighten people. Popular memory has these laws in existence in southern Oregon well into the early seventies, which partially accounts for the severely limited number of non-white lesbians in the land community.

${ }^{88}$ Crae, 11.

${ }^{89}$ Crae, 35.
} 
It is not surprising to find so few published accounts of attacks on the gay and lesbian communes within Oregon newspapers. In addition to the already established antagonistic relationship between local authorities and communes, gays and lesbians had a history of being harassed and arrested by the police for their sexual orientation, which further decreased the likelihood of land women reporting crimes or threats of violence to the authorities. In addition, there was prevalent drug use within the many of the communities in the early years, which included illegal marijuana plants as well as psychedelics. Local authorities used drug searches to come on to the lands and arrest members of the community, sometimes separating children from their mothers by placing them in foster homes..$^{90}$ The incidents decreased the likelihood of any community member turning to local police for assistance.

Instead a close examination of the southern Oregon lesbian land community's oral histories, autobiographical writing, and newsletters reveal a range of strategies for the establishment and maintenance of safe space. Carol Newhouse, one of the three founding members of the WomanShare Collective, located outside of Grants Pass, Oregon, wrote in their 1976 collective story:

We are not blatant about our lesbianism in the outside world. We live in conservative southern Oregon and with considerable justification feel we have to protect ourselves from downright hostility. On the other hand, if asked about our sexual identities, we do not hide. We hope people from the outside community will ask only when they are ready to know. We hope we are not being naive. ${ }^{91}$

\footnotetext{
90 Pelican Lee, OWL Farm Stories, (Ribera, NM: West Wind, 2002), 15-22.

${ }^{91}$ Sue, Nelly, Dian, Carol, Billie, Country Lesbians: The Story of the WomanShare Collective (Grants Pass, Oregon: WomanShare Books, 1976), 172.
} 
Carol's statement contains three meanings. The first is that the WomanShare Collective guarded its privacy and safety by refraining from openly identifying itself as lesbian to the surrounding community. The second is that the collective had a desire to share with the community their entire identity at a point in time at which the community was receptive. This strategy is one that was later employed by urban lesbian and gay activists in the midst of the AIDS crisis. ${ }^{92}$ The third connotation within Carol's statement is that while the collective was trying to balance the need for safety with the need for community involvement by only outing themselves when asked, there was still an unyielding fear for their safety--as she said: "We hope we are not being naive."93

Similarly, Jean Mountaingrove, one of the founding members of Rootworks, located outside of Sunny Valley, remembered her interactions with neighbors in terms of trying to create a safe environment through intentionally misleading them. She described having her daughter-in-law help her and Ruth:

I said that for Thanksgiving, which was not too far away, that if she would bake a pie, maybe four or five of them--I don't know how many it was at the time, then we would go to the neighbor, knock on the door, and say "Hello, we're the neighbors. Happy Thanksgiving! Here's a pie." We would be invited in, and we would talk. And we would talk about our children, and then they would say, "You want some beer?" "No, thank you." "Well, would you have a cigarette?" "No, thank you." And then I think we talked about maybe my experience as a social worker or Ruth's as a teacher or something like that. We just tried to come across as kind of boring nice people. I think it was a few years later that one of the neighbors down the road asked if Ruth and I were sisters, because we have the same last name. I said, "Yes."

\footnotetext{
92 The theory behind the strategy is that once someone gets to know a lesbian, grows to like and respect her before her sexual orientation is revealed, it is more difficult to justify anti-lesbian feelings and behavior. 93 Sue, Nelly, Dian, Carol, Billie, Country Lesbians: The Story of the WomanShare Collective (Grants Pass, Oregon: WomanShare Books, 1976), 172.
} 
Well, aren't we all sisters? ${ }^{94}$

Rather than wait for rumors or assumptions to develop around them, Jean and Ruth Mountaingrove intentionally set out to impress upon their neighbors the idea that they were "boring nice people," to protect them from harassment and prevent any interest in developing relations beyond that of friendly neighbors. By making it clear that they neither drank nor smoked, they set up a situation in which their neighbors would avoid inviting them to social occasions that would inevitably involve drinking and smoking. They also tried to connect with each of them using their commonalities, such as having and raising children, which may have also led their neighbors to assume them to be heterosexuals.

This memory also reveals the continuation of the maintenance of safe space through misleading information. After having lived there for a number of years, Jean points out that when asked a direct question about her and Ruth's relationship, she carefully avoided giving an answer that might lead to a potentially dangerous situation. Simultaneous to this strategy of diversion and misinformation, Jean reconstructed the meaning of sister, taking the established definition of a blood relationship and transforming it into one of gender and choice. Given her Quaker background, it makes perfect sense that she would choose to obfuscate rather than lie outright, a strategy that has historically been referred to as "passing." 95

${ }^{94}$ Jean Mountaingrove, interview with author (25 October 2010), 15.

${ }^{95}$ George Chauncey, Gay New York: Gender, Urban Culture and the Making of the Gay Male World, 1890-1940, (New York: Basic Books, 1994), 6-7, 103, \& 273-280. Chauncey also provides more background to the history gay safe space, and how passing was a strategy to maneuver within the "straight" world. 
Some land communities have faced intense conflicts and violence from which they could not recover. There were a number of lesbian lands that were lost, because their residents were not able to maintain safe space. ${ }^{96}$ This is especially true during the $1980 \mathrm{~s}$ following an influx of survivalists to the area. ${ }^{97}$ Survivalists could be described as the other end of the spectrum of back-to-the-landers, the opposite of the hippies. The survivalists that came to Oregon came fully armed and sought refuge from what they saw as the impending breakdown of social order. Many of these survivalists held strong beliefs in religion, politics, and family, all of which conflicted with the 1970 s back-to-the-land movement. Some survivalists were veterans of the Vietnam War, while others were followers of Mel Tappan, a columnist for Soldier of Fortune, and still others were involved with religious organizations like the Foundation for Human Understanding. The most extreme were those with connections to various white supremacy or neo-Nazi groups. ${ }^{98}$ At the 2012 Cabbage Lane Herstory Circle Gail, a former resident of the now nonexistent Speaker Road lesbian land community, described the survivalists as scary, especially as they were heavily armed. ${ }^{99}$

When faced with unruly individuals and unwelcome intrusions onto lesbian land, residents took more direct action, ranging from gates to locks to verbal and physical

\footnotetext{
96 There are numerous references and examples throughout the written record, as well as within the lesbian land oral histories that I collected. For examples, see: Hawk Madrone, interviewed by author (28 January 2011): 33 .

97 See for example: John Snell, "Ready for Worst Survivalists Secure in Oregon," The Sunday Oregonian, February 1, 1981, front page, Portland edition. And Kent Flanagan, "Farmhouse Stormed; Suspect Not There," Oregonian, February 16, 1983, A12, Portland edition.

${ }^{98}$ For a first hand account, see Snell,1.

99 This material is from my personal field notes, and the recorded Herstory Circle, which will be archived with the materials at the University of Oregon Libraries. See also John Snell, "Survivalists find comfort, protection in deadly arsenal," Oregonian February 1, 1981: B1.
} 
assertiveness. When Bethroot and Madrone first moved onto the land now known as Fly

Away Home, they encountered some resistance from neighbors. Madrone recalls:

Well, when we first moved here this house was unfinished and we both stayed in the trailer. One day two men, not old men, youngish men, carrying beer cans in their hands arrived at the trailer--partially drunk. They said they were looking for Jerry Schwarz, who was the former owner. Now they knew darned well that Jerry Schwarz hadn't lived here for a couple of years, so they were just wanting to check us out. And I was really angry, and I told them to "get the hell out of here." And they did, and we never saw them again, so that was the end of that. That's when we decided that we had to put something across the road, so we had a big huge rope that we tied across the road--so that people presumably couldn't drive up here. That eventually was replaced with a big huge chain. That was eventually replaced with--somebody gave us two old wooden gates, and these were eventually replaced by one that I made, etcetera, etcetera. Then we put a lock on it. ${ }^{100}$

In addition to the unwelcome male visitors to the land, Madrone also recounted another threat marked on their mailbox, "Lesbians get out! Somebody had written that on the mailbox, and I don't know if they wrote on it with pencil. Whatever it was I was able to take it away, so I got rid of it and never told Bethroot about it, because I was afraid she'd freak out."101 The removal of the words and that the rope was the subject of so many upgrades, including the final adding of a lock is telling. Perhaps the upgrades, like the removal of the writing, were simply for peace of mind, or they may have been responses to a real threat. Either way, that the women remained and asserted their right

\footnotetext{
100 Hawk Madrone, (interviewed by author 28 January 2011): 34-35.

101 Madrone, 35.
} 
to occupy space through various means demonstrates the importance of the space to the community and culture of the southern Oregon lesbian lands.

Because Roseburg and other southern Oregon towns and communities appear to have been less than welcoming of the lesbian land newcomers, residents of the lesbian land communities, like many of the back-to-the land communities that preceded them, were reluctant to advertise their locations. As one Oregonian reporter concluded, "They live in fear of the conservative community and are anxious that the assumption of too high a profile would provoke hostility." 102 This anxiety fluctuated along with the populations of the region.

However, some of the women interviewed indicated that the level of intolerance has changed over time. In some cases, such as at WomanShare, outside of Grants Pass, Billie Miracle explained that in the early years, people simply referred to them as, "The girls, the girls up the hill" without any real understanding of who they were. According to Billie that has changed, "There's only a couple of women living up there [on WomanShare] now, and the community [surrounding WomanShare] is more openminded. And the people that always were open-minded, that were always here, that were open and accepting are more visible." 103 Support from people outside the community had the potential to change the boundaries of the safe space, although aside from these interviews, there is little evidence of such a change.

The women of Fly Away Home also expressed how time has altered community attitudes. Fly Away Home, which was established in 1976, and the women have been there for over thirty years, long enough to garner some acceptance and respect from their

102 Foster Church, “'Redneck' community home of new lifestyles,” The Oregonian, July 22, 1979: B1.

103 Billie Miracle, interviewed by author (6 May 2011): 17. 
neighbors. ${ }^{104}$ For example, the neighbors, Jan and her husband share a road onto the ridge, and Jan's husband maintains that road in its entirety. Bethroot and Madrone have known Jan, a local woman, for as long as they have been there. Jan used to live in town, and prior to the recent availability of mobile phones, was their emergency contact.

Therefore, the disposition of Jan's husband was not all that surprising. According to Madrone:

So the fact that we were two women up here, and that we were lesbians was not a shocking thing for him. Plus, we had been here for close to thirty years. That gains a lot of respect with local people. When we first moved here we had to prove ourselves, but we've been living here--and he knowes. He's a good old boy from South Myrtle Road, and he grew up here, so he knows what it takes to live in this kind of environment. So I think he probably had pretty quick respect for the fact that these two women live up here and maintain a life up here. So he turns out to be very supportive, interestingly enough, and generous. And for almost thirty years Bethroot and I hand maintained that mile long road. We don't have to do that anymore, because he does it with machines. He can do in an hour what would take us days to do, so it's a huge--I mean, I would prefer it were a dyke with machines, but this is what we got!105

Perhaps even more interesting than this type of local support and changed attitude, is the fact that throughout the interviews neither Madrone nor Bethroot call Jan's husband by his name. In fact, I'm not even sure that they know it. It's hard to ignore the reversal of the earlier practice of female identity erasure. Prior to 1970, and even later in some places, women habitually took the entire name of their husbands. For example my grandmother, Margaret Eunice Evenson, became Mrs. George Ellis after marriage.

\footnotetext{
${ }^{104}$ Hawk Madrone, Weeding At Dawn, (New York: Alice Street Editions, 2000), 1-12.

105 Madrone, interviewed by author (28 January 2011): 37-38.
} 
That was the name she used on mailing labels, checks, and even her signature, a constant reference to her husband. Erasure of Jan's husband could be seen as an intentional rebellion or critique of a pre-existing hierarchy in the tradition of naming or as an oversight.

Naming is both powerful and important to lesbian feminist culture. By establishing the safety of their physical space, women gained a mental and spiritual safe space in which they could explore and reclaim or reconstruct their self-identity. ${ }^{106}$ For many this reclamation of self either began with or culminated in a name change. According to each of the women I interviewed, name changing was a common practice within the lesbian land community with many women choosing names that were reflective of the environment in which they lived or that held some symbolic significance. ${ }^{107}$ For some women the name change was simply a feminist reclaiming one's identity from a culture steeped in patriarchal thinking, one in which the father or male head-of-household claimed ownership over his offspring through the act of naming. For other women it was a release from the bondage of family expectations or a way of marking a new beginning, and rooting themselves within this new tribe, family, and culture.

Often this reclamation of naming had both personal and spiritual meaning, and community members chose names that reflected their evolving spiritual relationship with

\footnotetext{
106 Keridwen N. Luis, Ourlands: Culture, Gender, and Intention in Women's Land Communities in the United States (PhD diss., Brandeis University, 2009), 3. Luis addresses the opportunity for self-exploration created by women-only land, especially as it relates to gender norms and the gendered structure of patriarchy. 107 See for examples: Jemma Crae, interview with author 13 January 2011, 2; Hawk Madrone, Weeding At Dawn: A Lesbian Country Life (New York, NY: Alice Street Editions, 2000), xi;
} 
the earth. ${ }^{108}$ Hawk Madrone, a founder of Fly Away Home, is a prime example of a name change based on symbolic or spiritual significance. After moving to a cabin in the woods, Madrone changed her name to Hawk, in honor of a story that a philosophy professor told in class that she had taken as a college student. She felt connected to the image of a Red-tailed hawk circling overhead, and the name Hawk stayed with her for ten years. After moving to Fly Away Home she chose her second name:

A versatile tree, the madrone, and tenacious: on the government land at our northern boundary, the madrones were incised, to kill them slowly and make way for the growing marketable conifers. Shortly after I moved here, I walked among the standing skeletons of trees, and was amazed to find a few who had knit their wounds and still flexed their branches in the sun.

Madrone became my second name, as it was my second nature. ${ }^{109}$

The story is representative of how she felt at the time of the renaming. She weaves herself into a story of the tree for which she renamed herself.

Zarod Rominski's birth name is Frances Anne Therese Rominski. After living in the lesbian land community of southern Oregon for a while, she chose her new name, Zarod. Like many women within the community, she felt that her new life warranted a new name. In her description of the choice she tells a story of a walk in the woods that culminated in the name:

108 For a better understanding of this spiritual relationship see Hawk Madrone, Weeding At Dawn: A Lesbian Country Life, (New York: Alice Street Editions, 2000), and Musawa, narrator. In the Spirit of We'Moon: Celebrating 30 Years. (Estacada, OR: Mother Tongue Ink, 2010).

${ }^{109}$ Hawk Madrone, Weeding At Dawn: A Lesbian Country Life (New York, NY: Alice Street Editions, 2000), xii. 
So I was walking in the woods with a friend, talking about this, and all of a sudden I just threw my arms in the air and went, "Zarod!" --like that. This big sound came out of me, and I was like "wow!" And I looked at my friend, and I said, "I think that's my new name." And so from there on it was Zarod. ${ }^{110}$

Zarod expressed an interest in understanding where that name came from, and concluded that her Polish grandmother must have called her that as a baby, because in Polish the word 'zarod' is used as an endearing term meaning "little seed," the significance of which is not lost on her. ${ }^{111}$

Bethroot Gwynn's given name was Helen Elizabeth Gwynn. Those who knew her called her Betsy. She did not change her name legally, but took the name Bethroot before moving to Fly Away Home. She claimed that:

I was looking for a name by which to be called. I played with lots of possibilities, but I found that word in an herbal book, Jethro Kloss's Back to Eden book, and I liked the sound of it. It felt like it's connected still with my Elizabeth name, and it sounded both ethereal and grounded--Beth-Root. I liked that. I'm a Libra so I have certain dual propensities, and I found out--oh! It said in that herbal book that Bethroot was a member of the trillium family, a member of the lily family, and that it was used for female complaints. And then many years later, I also learned that it was said to be an aphrodisiac--so! ${ }^{112}$

Jemma Crae's experience of naming herself was different from Bethroot, Zarod and Madrone, in that she shunned the nature-based names often chosen by others in the community in favor of a more mainstream sounding name. For her the significance was

\footnotetext{
110 Zarod Rominski, interview with author (13 May 2011), 2.

111 Zarod Rominski, interview with author (13 May 2011), 2-3.

112 Bethroot Gwynn, interviewed by author (3 January 2011), 2.
} 
in the process, rather than the name itself. In her search for a more balanced life, she turned to numerology. Jemma remembered changing her name as a way of detaching from her family's rules and expectations. A name change gave her permission to reexamine her life and to break ties that were preventing her personal growth, specifically those with her mother. ${ }^{113}$ In her explanation of the transition to her new name she used words and phrases like "real self," "real desires," and "finding my own name" indicating that she saw her new name in the same light as she saw her self-realization, as something that has always existed but that she needed to find or rediscover: ${ }^{114}$

When I chose that Jemma name it really felt like it was me, and my personality bubbled up. She [the name] told me that I was a tank--that I could just persevere and do anything that I wanted, and I really felt my self-confidence improve from that moment on, when I did it legally. ${ }^{115}$

While changing one's name can be seen as either a literal or symbolic reclaiming of one's identity, the relative physical safety that lesbian land provided also afforded women the physical, mental, and spiritual safe space needed for self-discovery. One such example is evidenced in Bethroot Gwynn's interview. Before settling on women's land, Bethroot visited lesbian land for the first time in the summer of 1974, and in her 2011 interview constructed a story of self-discovery. She described hiking up a Cabbage Lane hill with Zarod:

${ }^{113}$ Jemma Crae, interviewed by author (13 January 2011), 2- 5.

${ }^{114}$ Jemma Crae, interviewed by author (13 January 2011), 3-4.

${ }^{115}$ Jemma Crae, interviewed by author (13 January 2011), 4. 
....and I don't know whether it was singing or shouting or screaming, but it was a very loud sound, and it came from inside of me, and it went on and on and on and on. It was as though it was not going to stop. And it was, for me, this incredible discovery of my voice. ${ }^{116}$

Stories of self-discovery or self-realization are repeated throughout all of the interviews. Bethroot's story construction centered around the themes of: her voice, which is symbolic of her power, her ability to express her own thoughts and feelings, her independence; being a theater womon, which gives her voice an audience and places value on her voice; and her separation from her mother, which she described as both painful and necessary for her own well-being. ${ }^{117}$

There was also a redefinition of what was possible. Women became more aware of their own abilities and desires. For example, in The Woman's Carpentry Book: Building Your Home from the Ground Up, Zarod Rominski described how the women of Cabbage Lane built Star Cabin. Zarod explained that each woman involved brought not only her own skills, but also fears and the negative messages of her upbringing. At one key moment in the story, one of the women tightens a bolt too much and it breaks. Her response is one of shock as she exclaims, "Why it was all a bunch of lies! I can tighten this bolt enough to break it!" 118 The purpose of this story was to dispel the misconception that women are weak. It also serves as an example of the capabilities of women to build their own homes, roads, water systems, and community infrastructure. Zarod's story is one example of how the women within the lesbian land community understood their experiences as changing

\footnotetext{
116 Bethroot Gwynn, interviewed by author (27 January 2011), 4.

117 Bethroot Gwynn, interview with author (27 January 2011), 4.

118 Frances Rominski, "Star Building," in The Woman's Carpentry Book: Building Your Home from the Ground Up, 190-199, ed. Jeanne Tetrault (New York: Anchor Press, 1980), 196.
} 
their own self-perception, and how story was written, published, and utilized as part of the building a women's culture that eschewed patriarchal thinking.

While reflecting on their experiences in 2010 and 2011, the women I interviewed placed much of the credit for their achievements on separatism, feminism, community, cooperation, and tenacity. Tangren Alexander said, "these lesbians, kind of exposed me to some feminism--in a sense of really what its upper reaches could be. You know, of women just really affirming each other, caring about each other, egging each other on."119

What was found in this safe space was community, not unlike that found in the earlier bar culture of the 1950s, documented by Madeline D. Davis and Elizabeth Lapovsky. Perhaps it is a space that is familiar: as Victoria of Cabbage Lane said, it is a "returning to a home I've never been before." ${ }^{120}$ In reflecting on their childhoods, most of the women I interviewed looked back with fondness at particular places in which they felt safe, loved, and able to be themselves. Jemma Crae described her youthful camping experiences as a time when she got to be outdoors with women. Madrone spoke of the summer camp as a place where, "I got to be my full self, without anybody bullying me, and I was well-loved." ${ }^{121}$ Childhood camping trips were temporary but as adults in search of community, many women sought the same feeling of safe space that their early experiences evoked. Once they created this space, it opened up room for new

\footnotetext{
119 Tangren Alexander, interview with author (12 November 2010), 8.

120 All of the Cabbage Lane Herstory Circle materials were recorded by land women with the intention of eventually transcribing and archiving the circles (as there were four throughout Oregon) at the University of Oregon, in the SOCLAP! collection. Zarod Rominski organized the Cabbage Lane Herstory Circles that is referenced here in February 2012 with the intention of providing the newest members of the commune with a connection to the past. The materials herein are from my field notes and personal recording. ${ }^{121}$ Hawk Madrone, interview with author (28 January 2011), 4.
} 
interpretations of individual and community identity. Along with that space came time, followed by choices of what to do with the time and space gained. 


\section{Chapter 3: Time to Create Lesbian Culture}

I think it's important for younger women to know that these women's lands exist and that women have gone into the woods, and made a life and their own food, and figured out how to make houses, and create infrastructure. And GROW-grow words, grow music, grow art--without a lot of the restraints, constraints, that exist in mainstream society.

--Bethroot Gwynn ${ }^{122}$

What was done in the safe space of the lesbian lands in southern Oregon is the subject of the this chapter. The creation of lesbian culture on the lands began as early as 1972 when women first came to Cabbage Lane, but really gained steam in 1974 after the first issue of Womanspirit, and began attracting women from all over the world as early as 1976, following the WomanShare Collective's publication of Country Lesbians. ${ }^{123}$ Then in 1978 and 1979 there were several books published that fictionalized women-only lands or women-only science fiction worlds, which stimulated women's imaginations and interest. ${ }^{124}$ Many women I interviewed credited both the works of fiction and the publications coming out of southern Oregon with attracting women from all over the world to the lesbian lands in southern Oregon. An increase in population led to an increase in creative culture, thus positioning the southern Oregon women's land community within a wider community, which stretched out beyond both the Pacific Northwest region of the United States and beyond the 1970s, impacting the present. As a

\footnotetext{
122 Bethroot Gwynn, interview with author, (27 January 2011), 46.

123 Sue, Nelly, Dian, Carol, Billie, Country Lesbians: The Story of the WomanShare Collective (Grants Pass, OR: WomanShare Books, 1976).

124 Suzy Charnas, Motherlines (1978) and Sally Gearhart, The Wanderground (1979) and Donna Young, Retreat: As it was! (1979) and Charlotte Perkins Gilman's Herland is republished in book form in 1979.
} 
result of creating, maintaining, and publicizing this rural communal space for women, by 1980 the southern Oregon lesbian land communities had become a hotbed of lesbian creative culture attracting poets, artists, and intellectuals from all over. Drawing from personal work experience, which included political organization, higher education, and social work, they organized, publicized, networked, and shared workshops, rituals, retreats, and publications. Newspapers and publications from this time period, and the oral histories of the women who where there illustrate how the creative activities of this community influenced and impacted women beyond Oregon, beyond the lesbian land communities, and beyond the 1970s.

This chapter will begin by defining some important ideas around identity and culture. Then I will address some of the anticipated counter arguments. After laying the groundwork for the discussion, I have broken down the culture created into five important areas: education, ownership, language, spirit, and art. After examining each of these at length, I will show how these cultural creations impacted a wider lesbian culture, outside of the lesbian lands of southern Oregon.

While it would be ridiculously impossible and irresponsible to define one universal lesbian creative culture, it is important to understand that in the face of repression there was a need for self-definition and group identification through art. Human beings strive to create order, and part of that struggle for order includes categorization and notation. ${ }^{125}$ Categorization inevitably leads to boundaries and their transgression by the ambiguity and complexity that is human life. For example, those who identify and categorize themselves based upon gender, sexual orientation, political choice, and their relationships

\footnotetext{
${ }^{125}$ Adam B. Seligman and Robert P. Weller, Rethinking Pluralism: Ritual, Experience, and Ambiguity (Oxford: Oxford University Press, 2012): 3-5.
} 
to others create an identity culture. In the case of the lesbian lands of southern Oregon, this culture is a lesbian feminist culture. This named category has changed over time, and its meaning depends upon both time and location. ${ }^{126}$

People hold many simultaneous identities, such as: woman, lesbian, Catholic, Filipino, artist, radical, vegetarian, and the list goes on. ${ }^{127}$ All of these identities affect one's perception of the world, as well as reception by the dominant culture, and even that boundary--the one between them, dominant culture and not, is regularly transgressed. In order to gain a deeper understanding of the time and space of 1970s southern Oregon, the people who occupied that time and space, within greater context of 1970s United States, and even the world, one has to rely both upon categories as well as individual experiences. We have to see the people involved in this culture creation as both autonomous individuals and members of a community. ${ }^{128}$

While the lesbian land communities of southern Oregon were not diverse enough to represent a greater lesbian identity, many of the women themselves had backgrounds that included political organizing for labor, women's liberation, and civil rights. ${ }^{129}$ It is from this background that many women took the "organize your own" theory into practice. ${ }^{130}$ In the early 1970 s, most activists viewed organizing within categories of race,

\footnotetext{
${ }^{126}$ For an excellent example of this shift over time, see Allen Drexel, "Before Paris Burned: Race, Class and Male Homosexuality on the Chicago South Side, 1935-1960," in Creating a Place for Ourselves: Lesbian, Gay and Bisexual Community Histories, ed. Brett Beemyn (New York: Routledge, 1997), 119-144. For a better understanding of location and sexual identity, see Martin F. Manalansan IV, Global Divas: Filipino Gay Men in the Diaspora (Durham, NC: Duke University Press, 2003).

127 Claude S. Fischer, To Dwell Among Friends (Chicago: University of Chicago Press, 1982), 193. Fischer uses interviews to examine human relations and networks within the urban environment to contest the lost community thesis. In several chapters he discusses the specifics of "subcultures" within cities that are based upon ethnicity and other identities held in common.

128 Seligman, 145.

${ }^{129}$ Gagehabib, 26-30. See also Gwynn (3 January 2011), 26-45.

${ }^{130}$ For a clear explanation of this: see Benita Roth, Separate Roads to Feminism: Black, Chicana and White Feminist Movements in America's Second Wave (New York: Cambridge University Press, 2004), 16-23.
} 
class, and sexual orientation as the only authentic way to organize. The "organize your own" principal included organizing your own, addressing other oppressions within that identity group. For example, a lesbian identified group might then address issues of race or class with in that group. ${ }^{131}$

It can also be argued that lesbian feminists created a unifying identity out of what Carol A. B. Warren called a unifying sense of community forged out of resistance to the heterosexual majority or even the secrecy that at times has enabled their survival. ${ }^{132}$ Or as one woman explained, "in the past we were so having to demand the right to be who we are, and that, interestingly enough, gave us such spirit, such pride."133 In essence, the culture in the making was also creating a unifying lesbian identity in the face of oppositional forces.

The mainstream culture of the 1960s was in many ways a struggle to hold on to the post-World War II nuclear family ideal, which glorified the heterosexual nuclear family and capitalist consumption. ${ }^{134}$ The counterculture that emerged in the 1960s in opposition to mainstream values with its back-to-the-land movement and associated communes seemed promising to many women. These communes continued the Beat Generation's questioning of American societal values and norms. The new strategies that had imbedded in them cultural critiques included shared money, property, sexual partners, work, and ideas. In practice, however, most countercultural offerings did not counter the gendered norms that classified women as second-class citizens. Most

\footnotetext{
131 Roth, 22-23.

132 For example see Carol A. B. Warren, Identity and Community in the Gay World (New York: John Wiley \& Sons, 1974), 13.

133 Hawk Madrone, interview with author, (28 January 2011), 44.

${ }^{134}$ For a succinct summation of evidence, see David A. Horowitz, The People's Voice: A Populist Cultural History of Modern America (Cornwall-on-Hudson, NY: Sloan Publishing, 2008), 310-312.
} 
communes still placed women in the kitchens and nurseries, and left most of the decisionmaking to the men. ${ }^{135}$ Fortunately, many of these women had experienced women's liberation groups and consciousness-raising, and would not settle for another variation of this gender paradigm. ${ }^{136}$

All of the women interviewed had been raised with gendered expectations that related to the nuclear family. These expectations included self-sacrifice, as exemplified by the interview with Billie Miracle:

Well, my parents always told me I had to have a job, so I could support myself if I ever lost my husband. And I always wanted to be an artist--since I was a little kid. My grandfather was an inventor, and I think that was the creative side of the family. So I always liked art, and I wanted to do art, but I knew you couldn't make much money, and my family didn't have much money or I would've gone to a fine arts school. ${ }^{137}$

In Billie Miracle's case self-sacrifice was a family imposition and personal obligation.

Because she needed financial security and according to her family could not rely on that security from a husband, she had to sacrifice personal desires to meet family expectations. The pressure of those expectations, as exemplified in Jean Mountaingrove's oral history, were sometimes not enough to hold back personal desire:

\footnotetext{
135 For example, Jean and Ruth Mountaingrove were members of the Mountain Gove Commune before joining the lesbian land community and Zarod Rominski was also a member of a mixed gender commune near San Francisco. There are numerous works in which gender inequality and the oppression of women on back-to-the-land communes is addressed. See for example, Kathleen Kinkade, A Walden Two Experiment: The First Five Years of Twin Oaks Community (1973) and Carol A. Kolmerten, Women in Utopia: The Ideology of Gender in the American Owenite Communities (1990). For more on the cultural revolution, see Miller, 3-8. 136 See for example, Robin Morgan, introduction to Sisterhood is Powerful: An Anthology of Writings from the Women's Liberation Movement (1970), xv-xxxiii.

137 Billie Miracle, interview with author (6 May 2011), 6.
} 
I didn't come back to take on a job in Los Angeles, which is what would have been the logical thing to do after a divorce. And my mother said, "Alright you've had time to recover. Where are the kids going to school? What are you going to do?" And I said, "Well, I'm not going back into that kind of work." I feel like it's a glass panel in front of me. It looks like what I'm going to do and what everyone would expect, and I cannot do it. Something in me will not do it. ${ }^{138}$

The women continued to counter the expectations and norms of heterosexual, patriarchal, white, middle class, suburban and consumerist culture within the southern Oregon lesbian land community. As Billie Miracle explained, "I think we wanted to see if we could do it differently than how traditionally people were living their lives."139 Their critique of mainstream society included a critique of gender roles, sexual expression, female beauty, the sexual objectification of the body, monogamy, and their own complicity with the patriarchal system of oppression, white privilege, economic class, private ownership, and personal responsibility. Although not unique to the lesbian intentional community, the community took these critiques to a deeper level by involving the purchase of land and restructuring of systems that had previously been taken for granted. Owning land and taking control of the construction and operation of their homes was outside of the gendered norm of the 1970s, and controlling the basic elements of food, water, and shelter gave women a greater sense of control over all other aspects of their lives leaving more space for creative risk taking. Critiques of mainstream social constructions were part and parcel of the lesbian culture they were creating, and can be broken down into five important areas: education, ownership, language, spirit, and art.

\footnotetext{
${ }^{138}$ Jean Mountaingrove, interview with author (23 September 2010), 9.

139 Billie Miracle, interview with author, (6 May 2011), 13.
} 
The first years of the community were difficult learning experiences that required a huge amount of physical labor. For instance, Bethroot spoke of the initial work of living in the country as "living on the edge of paradise and being overwhelmed with chores." 140 There was so much work to be done, that there seemed to be little time for anything else. One would think that only after the practicalities of living together in the forests of southern Oregon had become routine that the women would then turn their attention to creating culture, but that's not entirely the case in the lesbian land communities.

Somehow the women made time. For the most part, the material, spiritual, and linguistic culture of the southern Oregon lesbian land communities developed simultaneous to the practicalities. Nonetheless, the longer the women lived in the community the more the nature of lesbian culture creation shifted toward artistic expression. The early 1970s began with a search for affordable land. ${ }^{141}$ By 1974, women sent their creative endeavors out into the world via publications, performances, workshops, newsletters, and eventually the archives.

\section{$\underline{\text { Education }}$}

After the safe space was created, the women of this community set out to "share" and support each other through learning. Much of learning at the early stages of the community's development centered on practical or "how to" knowledge. Billie Miracle of the WomanShare Collective explained:

\footnotetext{
140 Bethroot Gwynn, interview with author (27 January 2011): 21.

${ }^{141}$ For example see Jemma Crae, interview with author (13 January 2011), 11. Jemma and her partner began searching for land in Oregon in 1971. Cabbage Lane was also purchased in 1972, WomanShare Collective in 1974, and Rainbow's End in 1975. For more information, see Cheney, 151-154.
} 
We had goals for ourselves, and we had goals for our work. I'd say that our goals for ourselves were to make a family, to learn to live together, and deal with shared responsibility and shared leadership, and somewhat shared money--not totally, but somewhat. I think we wanted to see if we could do it differently than how traditionally people were living their lives. And then our goal for our work was to bring feminism to more women, and to have a safe place where women could stay, and feel safe, and not have men present, and to teach young women--because we at times lived with children too. We wanted to learn new skills. We didn't know anything about chain-sawing or building or any of that. So we wanted to learn new skills, and then teach what we learned. As soon as we learned it (laughs) we wanted to teach it. ${ }^{142}$

Repeatedly, the women within the southern Oregon lesbian land community spoke of teaching, workshops, learning, and education. All of these references to community education are forms of resistance. Many of the women, such as Tangren Alexander, Billie Miracle, Hawk Madrone, and Bethroot Gwynn came from highly educated backgrounds. All of them earned advanced degrees, and many of them went into teaching before coming to the women's lands. Madrone expressed a great love for teaching, and continued to view herself as an educator after leaving academia in 1972.143 Taking education out of the classroom and giving it away gave women a sense of empowerment, as each of these women described the culture of learning within the land community. ${ }^{144}$

A safe space for education removed many of the obstacles to learning, as experienced by each of the women interviewed. For example, Madrone experienced difficulties teaching students that were only in her classroom to meet a degree

\footnotetext{
142 Billie Miracle, interview with author (6 May 2011), 13-14.

143 See Hawk Madrone, interview with author (28 January 2011), 25.

${ }^{144}$ See for example: Billie Miracle, interview with author (6 May 2011), 27-28.
} 
requirement. She also dealt with an unfriendly school administration, due to her sexual orientation and feminist identity. ${ }^{145}$ Similarly, in 1972, after years of studying theology at Union Theological Seminary, Bethroot Gwynn had to seek out historical references to goddesses, and teach herself what would later become the basis for the feminist spirituality, most often associated with women's land. ${ }^{146}$

Many of the lands have held a variety of workshops, some of which were free, and some were efforts to raise money to pay the property taxes or land payments. Fly Away Home held personal theater workshops, tai chi workshops, and writing workshops. ${ }^{147}$ WomanShare held a wide variety of workshops, including: sexuality, woodworking, weaving, crocheting, and photography. ${ }^{148}$

The workshops, social gatherings, celebrations, and work groups, which began as early as 1974 and gained in number and frequency between 1978 and 1982, served as a binding ingredient within the community . Without these gatherings and groups, the women living on lands separated by miles of forest would not have otherwise seen each other, much less developed lifelong friendships. These workshops, as well as community newsletters, served as both a venue for community communication and culture creation.

In 1980, Bethroot Gwynn and other women of Fly Away Home began holding personal theater workshops on their land. ${ }^{149}$ Within these workshops women used theater as a way to test out or experiment with their personal identity and behavior. Many reconstructed or re-connected with themselves in significant ways. ${ }^{150}$ In essence, the

\footnotetext{
145 See Hawk Madrone, interview with author (28 January 2011), 14-16.

146 Gwynn, (27 January, 2011), 3-5.

${ }^{147}$ Hawk Madrone, interview with author (28 January 2011), 29.

148 Cheney, 50.

149 The women were: Bethroot Gwynn, Hawk Madrone, Izetta, and Mariana.

${ }^{150}$ Bethroot Gwynn, interview with author (27 January 2011), 25-29.
} 
theater workshops and subsequent performances created a safe space within a safe space.

According to Bethroot, some women used the workshops for therapeutic work, and some even used them to try on a lesbian identity before coming out. ${ }^{151}$ Jemma Crae used the workshop to practice self-confidence:

I became this woman, Petra, and I was this woman that everybody valued. They looked up to me and all of my paintings were accepted and valued. It really gave me a good idea of what it was like to have really good selfconfidence. Petra was a name that I saw on that list. I thought, "Petra, I like that name too." So I took that name in one of Bethroot's workshops, and became a self-confident person, so I could realize what it was like to be self-confident. ${ }^{152}$

In addition to trying on self-confidence through theater, women also were able to put their lives on display for an audience. The interaction with the audience and the use of personal theater to address the personal, political, and social well being of both the performers and the audience is reminiscent of Augusto Boal's Theatre of the Oppressed, techniques for which he developed in the 1960s in Brazil. The sixth principle of Theatre of the Oppressed is "Every human being is capable of acting: to survive, we necessarily have to produce actions and observe those actions and their effects on the environment. To be Human is to be Theatre: the co-existence of actor and spectator in the same individual. This is the Subjective Theatre." Also, principle number nine:

The Theatre of the Oppressed offers everyone the aesthetic means to analyze their past, in the context of their present, and subsequently to invent their future without waiting for it. The Theatre of the Oppressed helps human beings to recover a language they already possess -- we learn how to live in society by

\footnotetext{
${ }^{151}$ Bethroot Gwynn, interview with author (27 January 2011), 29-30.

${ }^{152}$ Jemma Crae, interview with author (13 January 2011), 29.
} 
playing theatre. We learn how to feel by feeling; how to think by thinking; how to act by acting. Theatre of the Oppressed is rehearsal for reality. ${ }^{153}$

Like Boal, Bethroot sought to use theater to teach people to intervene and change their circumstances and as a consciousness-raising tool. Bethroot's personal theater workshops and performances can be seen as an example of the practice of subjective theatre or rehearsal for reality. The performances provided practice for acting and being in the world, a re-education.

This re-education played out in front of an audience, most often consisting of women from within the community, but as Bethroot's theater workshops gained popularity the audiences grew to include college students and women as far away as Portland, for whom getting to the lands was no easy task. The popularity of the workshops and performances was due in part to advertising, word of mouth and flyers, and also due to the popularity of some of the performers she attracted. The performance space moved from Bethroot's living space to more accessible venues in Roseburg, Corvallis, Eugene, Ashland, and Portland. ${ }^{154}$

\section{Ownership}

Questions about who should own the land, how it should be managed, the role of money and their relationship to it, as well as power relationships predominated among

\footnotetext{
153 See the International Theatre of the Oppressed website for full list of principles, http://www.theatreoftheoppressed.org/en/index.php?nodeID=23

${ }_{154}$ Jemma Crae, interview with author (13 January 2011), 28-29. See also Bethroot Gwynn, interview with author (27 January 2011), 29-33.
} 
women living on the lesbian lands in southern Oregon. ${ }^{155}$ In the early years, 1974 to 1978, many of the women within the community sought out and developed workshops on ownership and related issues, as a part of community and personal growth. ${ }^{156}$ Land ownership dominated these discussions about sharing. Some women within the community perceived landowners, women with their names on the deed, as having an unfair or disproportionate say in land decisions. The women on the deed, more often than not, were women with money, and therefore were seen as women with privilege. Sometimes the women on the deed returned to the cities, but still maintain a right to participate in land decisions. As a result some of the less financially advantaged women, who continued to lived on the land, saw them as taking advantage of their privilege at the expense of women doing the work of maintaining on the land. ${ }^{157}$

Zarod Rominski described an example of an attempt to share land, by giving the land over to another group entirely:

Well, I can talk more about Cabbage Lane. When we left that fall, when we decided that we weren't going to stay, we actually contacted a women of color group that had some land or had been living ---they had a name, um, they had been living on some land or ---I think they were connected to the Southwest-Thunderwoman was a part of that, I believe. I think they were at Lime Saddle. And we spoke to them and said that they could have this land. They could be the next group to come onto this land if they wanted it, and I think they did for a short period of time, but they didn't stay. I don't really know the story of that. I would guess that Wolf Creek and Grants Pass would be pretty difficult places for lesbians of color to make it. So that was a form of reaching out. It was still within the broader lesbian land culture, you know, because we knew

\footnotetext{
${ }^{155}$ For a more in-depth discussion on collectivism see Gagehabib, 170-172.

156 Billie Miracle, interview with author (6 May 2011), 13. See also Gagehabib, 49-50.

${ }^{157}$ For example, see Caroline Overman, "Cabbage Lane: Experiences of Caroline Overman," in Community Herstories: Living in Southern Oregon, ed. Tee A. Corinne (pink copy, ca. 1990: found in Tee A. Corinne Papers, Coll. 263, Special Collections \& University Archives, University of Oregon, Eugene, Oregon), np.
} 
these women who were in this other place. ${ }^{158}$

Zarod and her community were attempting to reach beyond the homogenous community that had developed around them to include a more diverse population of women with in the southern Oregon landscape. Unfortunately, that outreach did not result in permanent residents, a struggle that would be repeated in the future. There have always been obstacles to land ownership and relocation, gender and race are two, and money is another.

Money surfaces in all of the interviews--who has it, who doesn't, what to do with it, the responsibilities that come with money, and sharing it. On a philosophical level, many of the women within the southern Oregon lesbian land community express the desire to share what money they had, and attempted to make appropriate group decisions with money. ${ }^{159}$ Money was sometimes seen as a "burden" and "responsibility"--at least to those who had it. ${ }^{160}$ Many of the women interviewed had some form of inherited wealth, some worked seasonal jobs outside of the community, and almost everyone knew of someone who had been receiving some form of government assistance. ${ }^{161}$ No matter where money came from, the sharing of wealth was seen in a positive light. According to Zarod Rominski, "Women shared money in a way that was very inspiring."162 In fact,

\footnotetext{
158 Zarod Rominski, interview with author (13 May 2011), 29-30.

159 Sue, Nelly, Dian, Carol, Billie, Country Lesbians: The Story of the WomanShare Collective (Grants Pass, OR: WomanShare Books, 1976), 141.

160 For example, see Bethroot Gwynn, interview with author, (27 January 2011), 6-7.

${ }^{161}$ Jean Mountaingrove, interview with author (23 September 2010), 23. And Bethroot Gwynn, interview with author (27 January 2011), 42. And Zarod Rominski, interview with author (13 May 2011), 18-19, \& 41 .

162 Zarod Rominski, interview with author, (13 May 2011), 41.
} 
many of the land purchases and land payments relied upon women sharing what they could, pooling their resources for agreed upon expenditures. ${ }^{163}$

Solutions to these problems of obstacles to ownership, such as money, and the unequal power relationships that resulted from privilege, included an emphasis on sharing, which was sometimes abused. At times, women with valued personal property, such as a working motor vehicle, felt taken advantage of or had their property stolen. ${ }^{164}$ Other solutions included the use of group consensus for major decisions, workshops, consciousness raising groups, land trusts, and ultimately the purchase of Oregon's first open women's land, a land imagined and purchased by the community and open to all women.

In June of 1975 WomanShare held a three-day workshop questioning the relationship between money and power along with related issues, called "Money, Class, and Power." 165 It was from this workshop that the idea for OWL (Oregon Women's Land) Farm, open women's land, was formed. Previous to OWL Farm, all of the women's lands in southern Oregon were privately owned lands with varying degrees of openness to visitors, and various written or unwritten agreements between residents and those whose names were on the deed. ${ }^{166}$

Zarod Rominski recalled the inception of OWL Farm served as an inspirational example of sharing:

163 The SoClap! records contain numerous women's land newsletters asking for donations of money to go toward land payments and tax payments. See also, Hawk Madrone, Weeding at Dawn: A Lesbian Country Life (New York: Alice Street Editions, 2000), 1.

164 Gagehabib, 52-54.

165 This is also where the initial idea of a land trust was formed. See WomanSpirit 1977, reprinted in Community Herstories, 27. Also found in Cheney, 158.

166 Gagehabib, 49. 
Yeah, yeah, again, magical times, sitting in a circle--twelve, fifteen, twenty women talking about whether or not to buy this land, and saying: "Well, where are we going to get the money?" And it started being committed, with women saying, "I will commit." I mean, I don't know exactly what the numbers were, but I'll commit two thousand dollars. I'll commit five thousand dollars." Those of us that didn't have money were like, "My god! What's going on?!" But the women who had money were doing that, and then you know, everybody did something, even if it was a hundred dollars or twenty-five dollars or something. But you know, there were some big chunks of money that the women who had it were willing to put into it. It felt pretty powerful. It was powerful. ${ }^{167}$

The fact that women came come together over the course of several months in the summer of 1976 , and raised $\$ 18,500$ for a down payment on 147 -acres of land to be shared with any woman who wanted to live there is remarkable, especially considering that the U.S. economy was only showing a slight improvement following years of sharp inflation and high unemployment. ${ }^{168}$

Following the establishment of the OWL Farm, women within the community began to examined the financial and legal ownership status of the lands more closely, and over time they took steps to re-organize into nonprofits. The Oregon Women's Land Trust (OWL Farm) is the only federally recognized 501(c)3 non-profit. ${ }^{169}$ Oregon Women's Land, Cabbage Lane, Rootworks, and Rainbows End are registered Oregon non-profits. Oregon Women's Land registered in 1975. Cabbage Lane became a registered nonprofit in 1992. Rootworks became a nonprofit in 1997. Rainbows End was

\footnotetext{
167 Zarod Rominski, interview with author (13 May 2011), 28.

168 Cheney, 159. Also see WomanSpirit Spring Equinox, Vol. 3 no. 11,(1977).

169 "EIN\# 93-0674461 Oregon Womens Land Roseburg OR United States," from the IRS database, accessed on 29 April 2013, <http://apps.irs.gov/app/eos/pub78Search.do?indexOfFirstRow=1325\&exemptTypeCode=\&isDescendi $\mathrm{ng}=$ false \&totalResults $=1909 \&$ postDate $\mathrm{To}=\&$ ein $1=\&$ state $=$ OR\&dispatchMethod $=$ searchCharities\&postDa teFrom $=\&$ country $=U S \&$ city $=\&$ searchChoice $=$ pub78\&indexOfFirstRow $=1300 \&$ sortColumn $=$ name $\&$ result sPerPage $=25 \&$ names $=$ Oregon + Women $\% 27 \mathrm{~s}+$ Land + Trust\&zipCode $=\&$ deductibility $=$ all $>$
} 
registered in 1998.170 Other lands remain privately owned with one or more of the residents listed on the deed. In addition to the incongruence of privately owned land with the aspirations of the lesbian intention community, these privately held lands leave themselves open to the dangers of lawsuits and government seizure.

\section{Language}

The women's land movement challenged patriarchy on all fronts, including language, the signifiers of the world in which they lived. Part of their power and ability to create a world in which they wanted to build community was the transformation of language. Delving into their search for connections with women of the past, a search that went beyond the boundaries of the United States and even their own ethnic heritage, land lesbians embraced all women, the diversity of women, and relished in claiming through renaming. ${ }^{171}$ In addition to shrugging off the names of their fathers, the removal of masculine imagery, and words that were perceived as oppressive, land lesbians also played with language. ${ }^{172}$ Words like woman and women became womon or wemoon or womyn or wimmin, seminar became ovular, menstruation became moonstruation, history became herstory, and so on. ${ }^{173}$ Just as the lands themselves seemed otherworldly,

\footnotetext{
170 This means that they are recognized by the State of Oregon as nonprofits, as documented in the State database, accessed on 29 April 2013, < https://data.oregon.gov/Business/Active-Nonprofit-

Corporations/8kyv-b2kw> Cabbage Lane and Rootworks are public benefit nonprofits, and Rainbows End is a mutual benefit nonprofit.

${ }^{171}$ Musawa, In The Spirit of We'Moon: Celebrating 30 Years (Estacada, OR: Mother Tongue Ink, 2010$), 7$.

172 Billie Miracle, interview with author (6 May 2011), 2. See also Musawa, In The Spirit of We'Moon:

Celebrating 30 Years (Estacada, OR: Mother Tongue Ink, 2010), 7.

${ }^{173}$ Musawa, In The Spirit of We'Moon: Celebrating 30 Years, 7.
} 
the play on language and communication added to the disconnect from the patriarchal mainstream from which they evacuated.

In addition to changing of words to eradicate the language of patriarchy, women also used non-communication or silence, non-verbal communication, and song within their communities. Tangren Alexander described one of her first encounters with lesbian culture and communication:

I remember one of the things that I learned right then was how when you'd approach a woman's tent you would like woo woo heredeepooseewen, singing back and forth, you know, across the meadow. It was just this really nice way of letting yourself be known. It was one of my first little things about lesbian culture, I guess. ${ }^{174}$

The land women viewed all women, globally, as interconnected. This interconnectedness can be seen in their reclamation of language and story, as well as the lingual traditions of oral storytelling, song, and writing. ${ }^{175}$ Ruth and Jean Mountaingrove also began a publishing house called New Woman Press, which published a few local women writers. One of the publications was Ruth Mountaingrove's The Turned-On Woman's Songbook (1975). ${ }^{176}$

The song culture of the southern Oregon lesbian land community merged creativity and ritual, and served as a bonding element across lands. Tangren Alexander described the origins and types of songs:

174 Tangren Alexander, interview with author (13 February 2011), 11.

175 Gagehabib, 90-93.

176 Cheney, 126. See also The Lesbian Poetry Archive website:

http://www.lesbianpoetryarchive.org/node/266 (accessed on 6 March 2012) 
Oh, it's songs that get sung in circles around here still. I think some of them come from other pagan traditions. It's like, you know, let me think of the words now. (singing):

Hoof and horn. Hoof and horn. All that dies shall be reborn.

Corn and grain. Corn and grain. All that falls shall rise again.

You'd sing that over and over in kind of this chant, or there's another part to it that goes, (singing):

We all come from the goddess, and to her we shall return, like a drop of rain, flowing to the ocean. ${ }^{177}$

As Tangren explained above, it is apparent that song is one element that brings the community together. Everyone knows the songs. One person can start a song, and others can join in. There is often the use of call and response or other playful interactions between members in a group singing. ${ }^{178}$

$\underline{\text { Spirit }}$

Throughout the 1970s and 1980s feminist spirituality held sway on lesbian land. There were circles, rituals, writings, songs and publications dedicated to goddess worship and the cycles of nature. Women sought out and created a spirituality that fit with their feminist politics and land based living. There are examples of the continuation of many of

\footnotetext{
177 Tangren Alexander, interview with author (13 February 2011), 15.

178 This was also witnessed, by the author, at Bethroot Gwynn's 70th birthday celebration, which took place at Fly Away Home in 2012.
} 
these practices among the women who remain, such as Croning ceremonies, Solstice celebrations, and death rituals. ${ }^{179}$

Madrone's early memories provide some insight into that unique combination of work and spiritual fulfillment:

When we first were here we, Bethroot and I, started having--with Rainbow's End women--I think it was New Moon circles. A few of those we did. I'm trying to remember other kinds of visitations. In the first years we had work parties, so I remember work parties here. I remember work parties at Rainbow's End. I remember going to Rootworks several times for various occasions--birthday celebrations, croning ceremonies, and that kind of stuff. We had circles here every Equinox and Solstice. I don't remember exactly when they started, but pretty early on. ${ }^{180}$

All of the women who were interviewed participated in and had a deep connection to the established feminist women's spirituality that developed on these lands and in the wider lesbian culture of the 1970s and 1980s. Three of the women who were interviewed (Jean Mountaingrove, Zarod Rominski, and Bethroot Gwynn) had a personal history and connection to organized religion before moving onto the land. ${ }^{181}$ Two of the women interviewed (Tangren Alexander and Hawk Madrone) were philosophy professors, and another two (Jemma Crae and Dana MacDonald) were active in the Unitarian Universalist Church. ${ }^{182}$ All of these connections between faith, theology,

\footnotetext{
179 Bethroot Gwynn, interview with author (27 January 2011), 3. See also Dana MacDonald, interview with author (13 January 2011), 28.

180 Hawk Madrone, interview with author (28 January 2011), 29.

${ }^{181}$ For more information on Jean Mountaingrove, see Jean Mountaingrove, interview with author (23 September 2010), 9. For more information on Zarod Rominski, see Zarod Rominski, interview with author (13 May 2011), 11. For more information on Bethroot Gwynn, interview with author (3 January 2011 ), 8 \& 20-26.

182 See Tangren Alexander, interview with author (12 November 2010), 4. And Hawk Madrone, interview with author (28 January 2011), 3 \&12-13.
} 
philosophy, and spiritual practice came together in the lesbian land community. The women worked together to create a practice that reflected their influences infused with the physicality of this land based or ecological way of life. Without this last influence, the physicality of land based living feminist women's spirituality would not have become what it is today.

\section{Jean Mountaingrove remembered her first experience of having a spiritual} connection to nature while on the land in Oregon. This experience initiated her journey away from the Quaker religion and toward a nature and goddess centered spiritual practice:

The Quakers are--I don't know if you know much about them? [HB makes a hand signal indicating a little bit] Okay, they're very nonviolent peaceful people. Their principles I believe are ones I believe in, and I don't know more to say about it except that Ruth had a friend--I think it was some aunt or something who was a Quaker, so when we got together we went to Quaker meetings in wherever--Portland or Eugene or San Francisco--wherever we went. And I only had one time in which I felt unconnected and that was when-there was some kind of a circle the Quakers did, and I could go to them for guidance or whatever--and I spoke of my strong moving with nature and I did not feel that that was understood or received very well, and so I withdrew emotionally from that--on that point. That was back in 1973 or 1975 or something. I do--I have had--there was--we're going to get into this a little more-ahh. As I roamed the land I found myself in a small group of trees near a little stream, and I felt strangely moved. I experience what I could say was unconditional love. In that space I could do nothing wrong. I could do anything I wanted to do. I didn't have to do anything. I was loved--just me, just me. And I was then drawn to--I hate to say tree hugging, because it sounds so automatic or something. I did not know anything about tree-huggers, nothing at all, but I was drawn to hug a tree, put my face against the bark and listen, and feel loved. ${ }^{183}$

${ }^{183}$ Jean Mountaingrove, interview with author (23 September 2010), 12. 
Quaker practices include the development of a personal relationship with God that is always revealing itself, most often in stillness. Even though, there was a part of Jean that withdrew from the Quakers, she still felt a connection, because she shared their principles and beliefs that include: "peace, truth-speaking and integrity, equality, simplicity, and reaching out to that of God in every one." ${ }^{184}$ Jean tried to live these principles through her social work in Los Angeles, and left the work frustrated by what she saw as a bureaucratic system that lacked regard for the women and children it purported to serve. ${ }^{185}$ After leaving Los Angeles and spending time at Pendle Hill, a Quaker retreat in Pennsylvania, Jean eventually made her way to the lesbian land community in southern Oregon in the early 1970s. She attended the 1973 Country Women Festival in Albion, California. It was there that she learned more about the business of publishing and the networks of lesbian feminists that could be utilized for collaboration, creation, and marketing. ${ }^{186}$

In 1974, after helping them with their issue on spirituality, the publishers of Country Women magazine encouraged Jean and Ruth Mountaingrove to publish a quarterly magazine of their own entirely on women's spirituality. The magazine, WomanSpirit, was first published in the Fall of 1974, and was a collective effort employing the work of women from the network of lesbian intentional communities in southern Oregon and nearby cities.

\footnotetext{
184 Taken from the Pendle Hill website, Pendle Hill being a Quaker education center in Pennsylvania that Jean Mountaingrove spent time at following her divorce from her second husband and before she moved to Mountain Grove. See <http://www.pendlehill.org/vision-mission-and-history> accessed on 29 April 2013. For more information on Jean Mountaingrove's perspective see Jean Mountaingrove, interview with author (23 September 2010), 9.

${ }^{185}$ Jean Mountaingrove, interview with author (23 September 2010), 6.

186 Barbara J. Love, Feminists Who Changed America 1963-1975 (Urbana: University of Illinois Press, 2006), 327.
} 


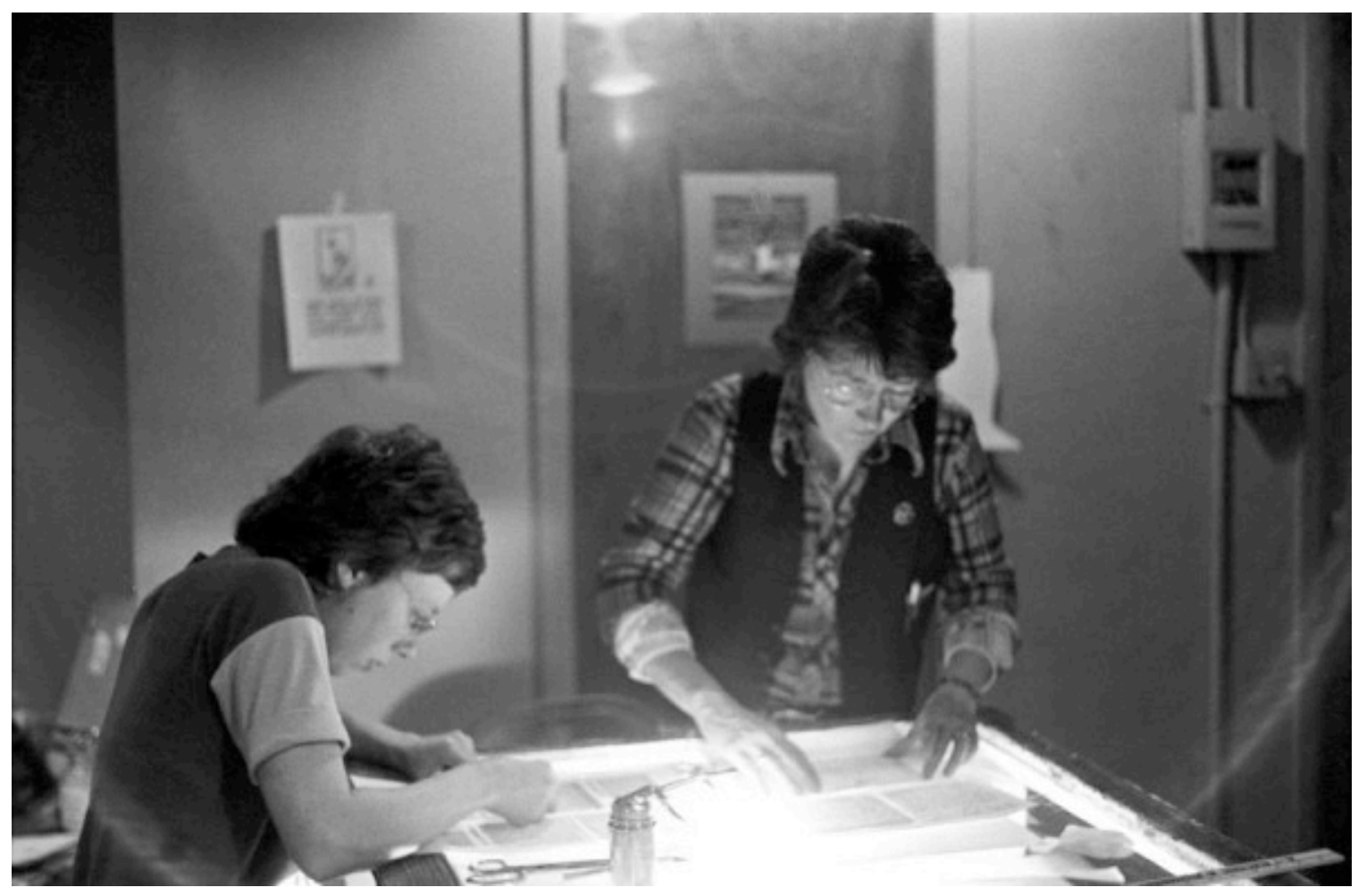

Figure 2: Portland WomanSpirit 1975, http://oregondigital.org/u?/comm,659 University of Oregon Libraries, Ruth Mountaingrove Photographs, Collection 309

Women within the community contributed the initial funds for printing and postage. The first issue of WomanSpirit's was printed in Eugene, Oregon, and distributed through a nationwide network of about twenty-five women's bookstores. ${ }^{187}$ Women from both the lesbian land communities and some of the cities came together to produce it, rotating the location of the production to accommodate the group. ${ }^{188}$ According to Jean, after the magazine had been out for a few years, it began to draw women from all over the country:

So Ruth and I focused on our feminism and going places to be with other women,

\footnotetext{
187 See Jean Mountaingrove, interview with author (23 September 2010), 16-17.

188 For example, see Hawk Madrone, interview with author, (28 January 2012), 27. Madrone participated in the production of an issue from Rainbow's End.
} 
and then all of these women would come to work on the magazine. We didn't have electricity there, so we had to find some other place--somebody's house or someplace where they were renting it...all kinds of strange places. We did it in Portland in the Quaker's children's room upstairs. We couldn't meet there Sundays. All kinds of places. ${ }^{189}$

For ten years WomanSpirit magazine published in this manner, by and for the lesbian feminist community. It came out four times a year, on the equinoxes and solstices. The last issue was published in the summer of 1984. WomanSpirit magazine had been a material expression of a new kind of spirituality, which had taken root among land women in the 1970s. ${ }^{190}$

189 Jean Mountaingrove, interview with author, (23 September 2010), 21.

${ }^{190}$ Jean Mountaingrove, interview with author (23 September 2010), 17-21. 


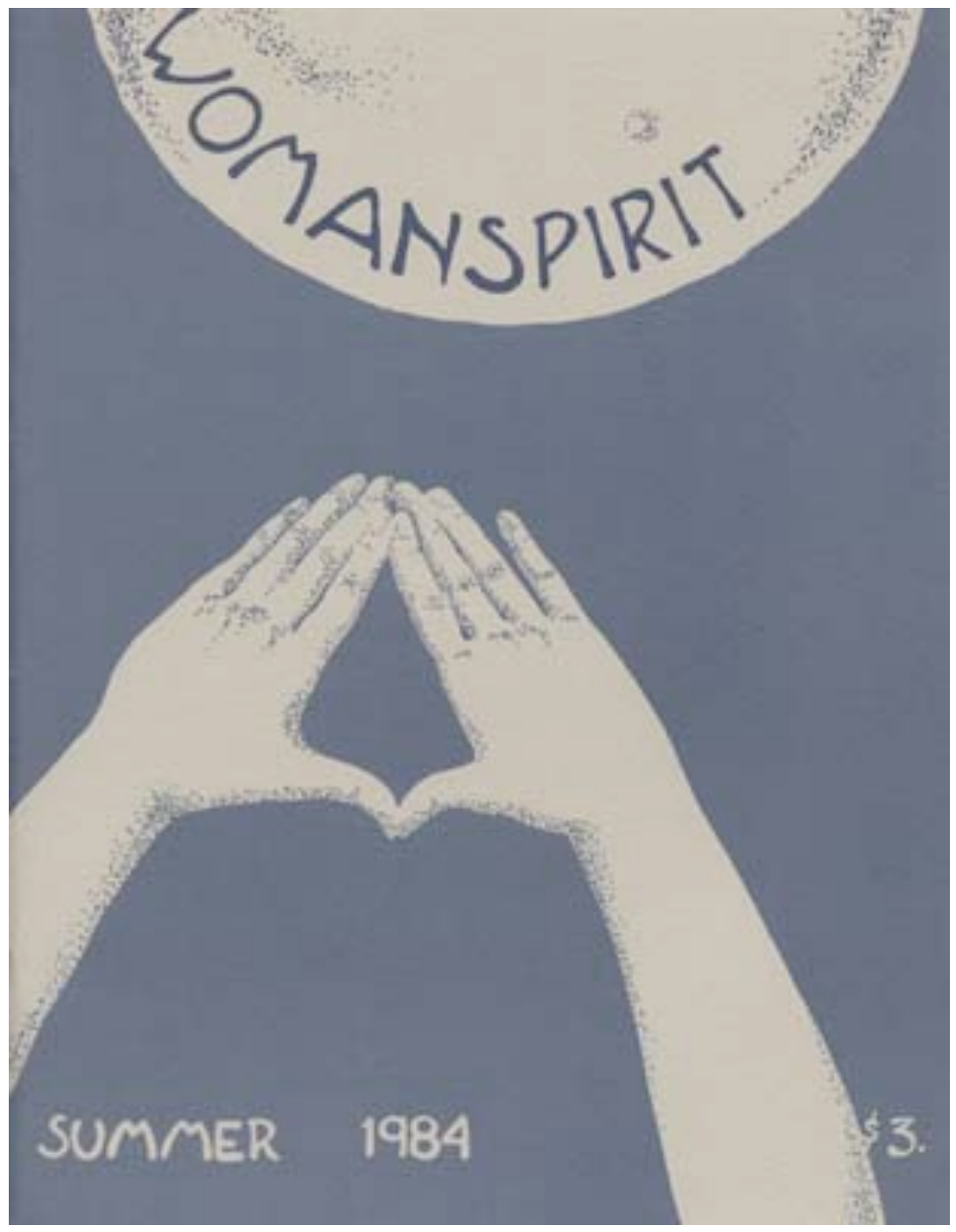

Figure 3: Front Cover, Summer 1984 issue of WomanSpirit magazine ${ }^{191}$

In 1974, Womansource, a feminist cultural organization that was based in

Ashland and produced many women's music concerts for the area, organized an annual

Womansource Fall Gathering in Oregon to bring together the larger network of West

Coast women's lands and feminist communities. The Fall Gathering initially took place at

Lake of the Woods, Oregon, and was held annually for over thirty years. It discontinued

${ }^{191}$ Front Cover of Summer 1984 issue of WomanSpirit magazine permission to reprint from Jean Mountaingrove and WomanSpirit magazine's website on May 29, 2012 
in 2003, was revived again in 2005, and the last gathering was held in 2007. The gatherings were women-only campouts that included music, workshops, and spiritual circles. ${ }^{192}$ This gathering was an annual highlight in many women's lives, as evidenced in each of the interviews. ${ }^{193}$

Bethroot Gwynn, of Fly Away Home, was one of many who were deeply drawn to the spiritual aspect of the counterculture, and articulated the connection between land and spirit:

It's northern California, Oregon, and New Mexico that you can think about as kind of a triangle for women who were doing spirituality, living on land. Some of those women were involved in the creation of Oregon's Women's Land Trust. Some women who were involved in the beginnings of OWL Farm and lived there then decided to go to New Mexico, because of the sun. And so there was a lot of travel among those places. There was a group of lesbians sort of on the road between northern California, Mendocino County, and Oregon looking for land. The idea for a women's land trust got born in 1975. So I was a part of that enthusiasm for the magic of the natural world, creating out own ceremonies, our own rituals. No more patriarchal religion stuff. And for me to discover that creating our own worship with song, that could be a part of it, was absolutely crucial. That was sort of the final brick that fit into place. ${ }^{194}$

She believed that the women's land movement was intimately connected to a transformation in the way that women saw themselves and interacted with the world. Women relieved themselves of the many parts of patriarchy: Christianity, market consumerism, capitalism, "traditional" marriage, and heterosexuality. She repeatedly

\footnotetext{
192 Some of this is detailed in Dana MacDonald, interview with author, (13 January 2011), 11. See also, Gagehabib, 13-15.

193 For example, see Tangren Alexander, interview with author, (13 February 201 1), 24-26.

194 Bethroot Gwynn, interview with author, (27 January 2011), 5.
} 
refers to this time period, 1974-1976, as magical, suggesting its significance. She said that there was an "enthusiasm for the magic of the natural world," and when speaking of the serendipity of receiving unexpected money just when she needed it, "part of the magic of those years." 195

It wasn't magic that brought the We'Moon datebook to Oregon in 1987. The idea originated at Kvindelandet, a women's land in Denmark in 1979, but in 1980 Danish Oil and Natural Gas had begun drilling right next to Kvindelandet, an intrusion that ultimately led to the community's final collapse in 1983. The initial intrusion of Danish Oil and Natural Gas included three drilling rigs that formed a triangle around the women's community and a number of male workers who some women witnessed watching them through binoculars, and even filming them as they worked in the fields. ${ }^{196}$ This initial intrusion was enough to drive many women away from the land, and the publication of We'Moon moved to a women's land in France in 1981. Then Musawa brought the production with her to We'Moon land in 1987, which was then called WHO Farm. ${ }^{197}$ According to its publishers, "The WE'MOON originally was written in several languages, reflecting the international culture of women's lands in Europe, where it began. Moving across the man-made borders we look to the moon, sun, planets and stars overhead and the earth under our feet in all her elements...to give us direction." 198 The publication of the datebook continued in 2013.

\footnotetext{
195 Bethroot Gwynn, interview with author, (27 January 2011), 6.

196 Cheney, 61-65.

197 Musawa, In the Spirit of We'Moon (Portland, OR: Mother Tongue Ink, 2011), 24. See also Cheney, 61.

198 Box 11, Folder 38, Series IX We'Moon Publication Information/Mother Tongue Ink, SO-CLAP! Collection, Coll 266, Special Collections \& University Archives, University of Oregon, Eugene, Oregon.
} 
Some scholars have categorized these spiritual practices as ecofeminist, which is an easy correlation to make. Many of the ecofeminist writings that came into vogue in the early 1990s were influenced by some of the same ideas and writings as the women within the land communities, and quite possibly there are some women who have lived within the southern Oregon community that may self-identify as such currently or at some point in the recent past. The women's spirituality of the lesbian land community predates the intellectual scholarship of ecofeminism, and none of the women interviewed offered up ecofeminist as a self-identifier. For many land lesbians, growing your own food was a revolutionary act, and thanking the earth and for the abundance was a spiritual practice, but one that was not theorized.

The spirituality of the various land communities has changed over time. Some women continue the same feminist spiritual practices that were developed in the early years; others have shifted to or combined them with other practices, such as Buddhist meditation or Unitarian Universalist Church communities. ${ }^{199}$ Spiritual practice was seen as both a community and personal experience, as Jemma Crae explained:

I've also been interested in exploring my spirituality. I have three areas that I'm interested in. I've always been going to the Equinox and Solstice Circles, and I consider myself a pagan. But I'm also interested in meditation and Buddhist faith. I'm not, I don't consider myself a Buddhist, but I do meditate. I also am interested in Taoism, but where I can bring all of those together is the Unitarian Universalist faith, and we have a Unitarian Universalist Church in Roseburg. I've been active in it for at least sixteen-seventeen years, since 1988. ${ }^{200}$

\footnotetext{
199 Dana MacDonald, interview with author (13 January 2011), 19. See also Jemma Crae, interview with author (13 January 2011), 26-27.

200 Jemma Crae, interview with author (13 January 2011), 26-27.
} 
Notice that Jemma Crae initiated the discussion of spirituality with the declaration that she has always and continues to attend the lesbian land community circles. Dana MacDonald also explained how these circles and other spiritual practices continued to hold the community together:

We come together for equinoxes and solstices, as you know, at Fly Away Home, and we carry on--Whispering Oaks has a pond party every year that's a group gathering that any women can come to. We have dances here, that women come, and ten or twelve women have been known to spend the night. So the community--you crossover, you know, depending--other women's lands have fires or when women die we come together around their deaths. On New Year's Eve down at Fishpond or WomanShare there was a big circle bonfire memorializing Sally Smith's death, which happened at Thanksgiving. Friends went to that; we did not attend that one. But the women come together, who feel like it's an appropriate time and place for them to be, in a particular situation, depending upon--if it's a death or if it's a party or a concert or so on, so it depends on the nature. ${ }^{201}$

$\underline{\operatorname{Art}}$

The creation of art put into words and images the lives and experiences of women in general, and lesbians specifically for the first time. Through independent women's presses, women's bookstores, and art galleries it gave lesbians a creative expression to which they could relate. It also gave lesbians permission to express themselves through their own art. Many lesbian artists travelled the country promoting their work, holding workshops, and encouraging others to similarly express themselves through art and writing. For example, a group of women, who included Tangren Alexander, Zarod

${ }^{201}$ Dana MacDonald, interview with author (13 January 2011), 19. 
Rominski, and Jean Mountaingrove, started a writers' group in 1980, following a workshop with Martha Courtot, a lesbian poet from Santa Cruz. They eventually named the writers group The Southern Oregon Women Writers' Group, Gourmet Eating Society and Chorus, and continued to meet every three weeks, as of 2010. ${ }^{202}$

202 Tangren Alexander, interview with author (12 November 2010), 21-22. 


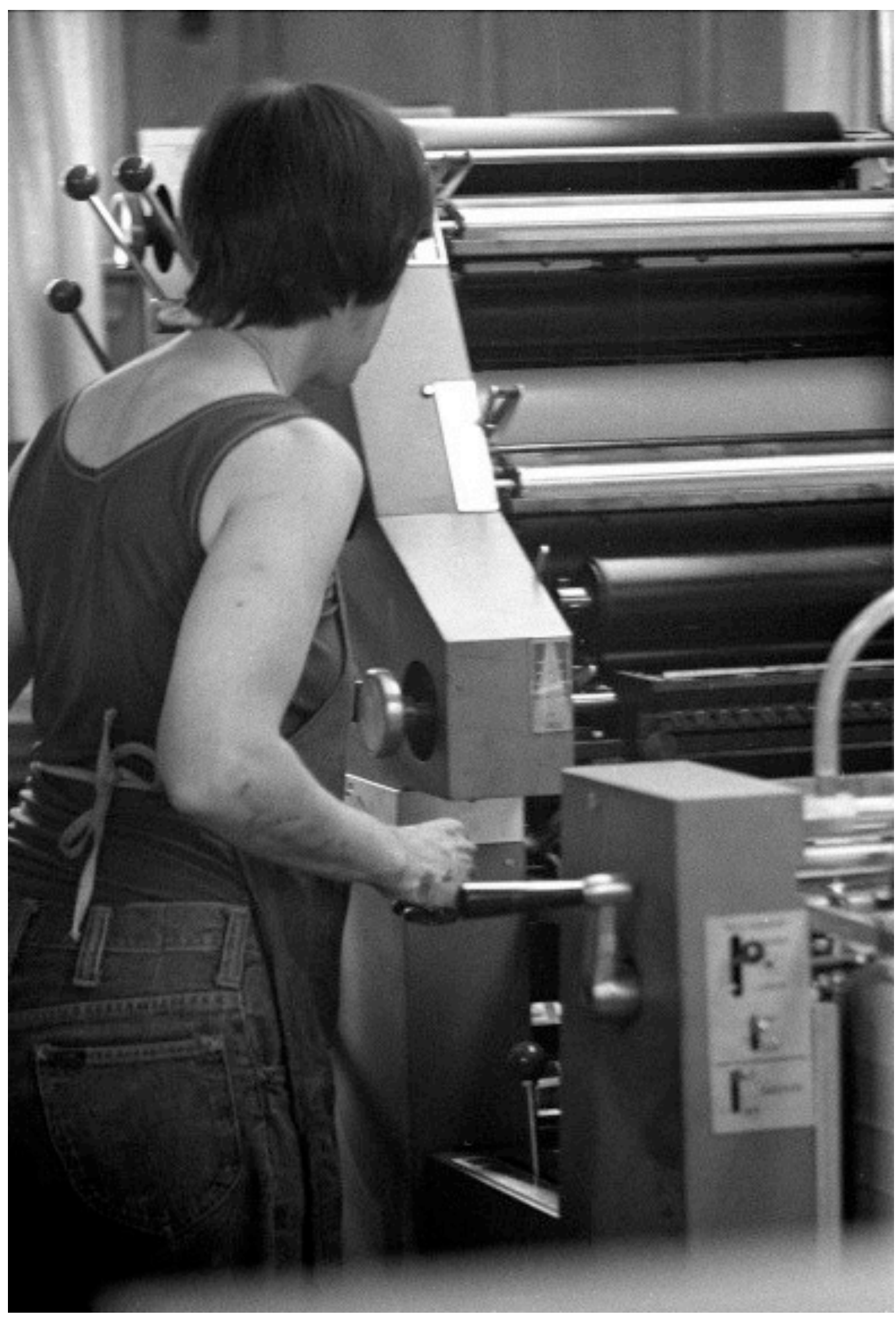

Figure 4: Baltimore, MD. Diana Press 1976, http://oregondigital.org/u?/comm,476, University of Oregon Libraries, Ruth Mountaingrove Photographs, Coll. 309 
Both the We'Moon datebook and WomanSpirit magazine solicited art, poetry, and literature from women throughout the world. They used the newly created network of independent women's bookstores and women travelers to spread word of their publications, and the need for artistic contributions. These publications coincided with a boom in lesbian and feminist publications from 1972-1985, which included: Sinister Wisdom (1976), Country Women (1973), Ms. Magazine (1972), Diana Press (1972), Naiad Press (1973), Spinsters Ink (1978), Kitchen Table (1980), and many others. The southern Oregon lesbian land community used its available resources: time, space, women, skills, and creativity to develop publications, workshops, performances, art, and music. They used methods that were familiar to the women's land culture, including group consensus, shared labor, shared space, networking, and an open space for learning.

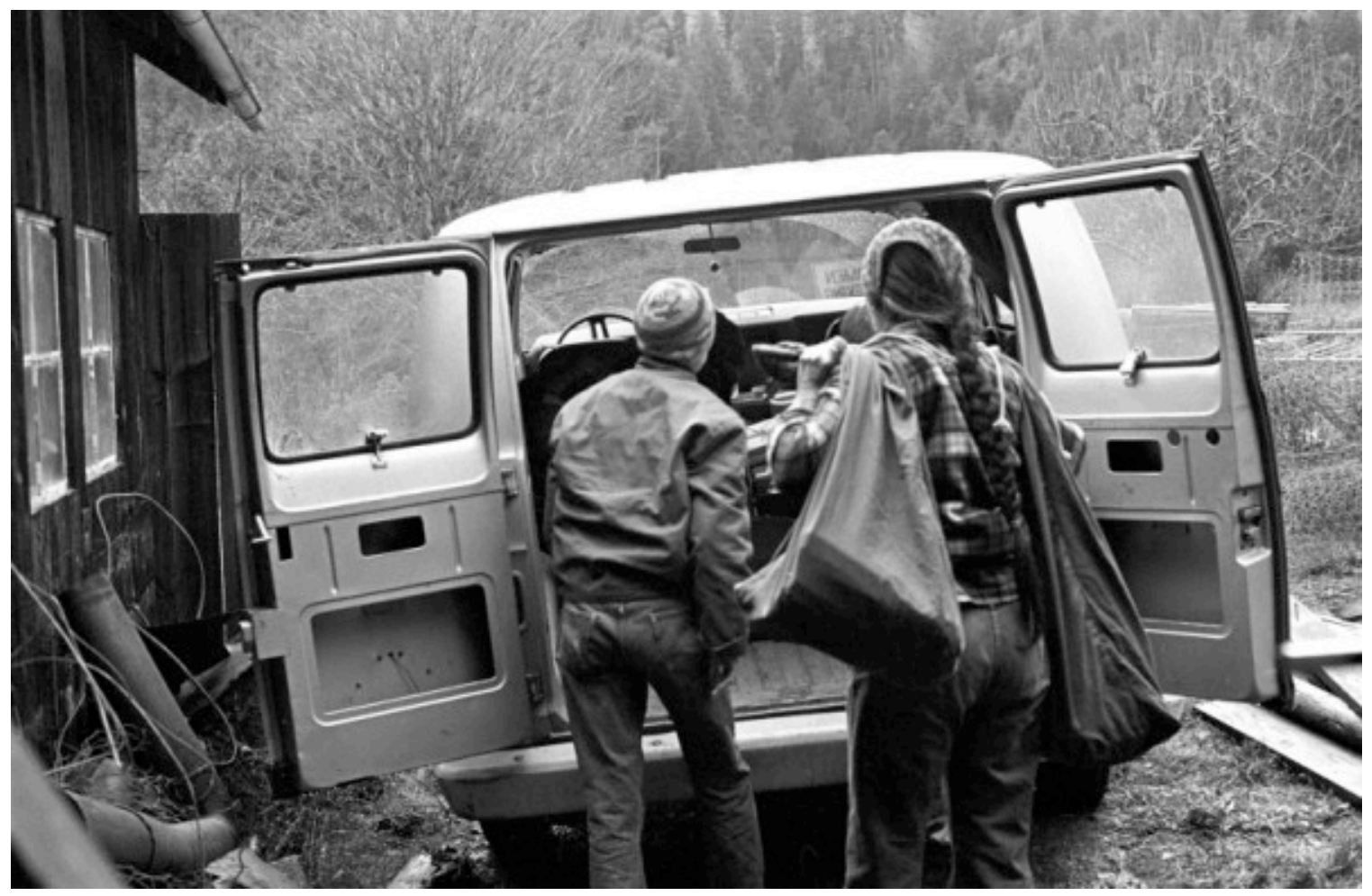

Figure 5: Golden office, loading WomanSpirit for distribution at the post office 1977, http://oregondigital.org/u?/comm,607, University of Oregon Libraries, Ruth Mountaingrove Photographs, Collection 309 
Many of the women interviewed credited the publication of WomanSpirit magazine with the initial draw of women to southern Oregon. The continual flow of women between lands, especially in the summer, led to artist, photography, and writing workshops.

In 1979 the first Ovular (feminist for seminar), a feminist photography workshop, was held at Rootworks. The women from the Ovulars, who were interested in creating a magazine, put out calls for photographs and articles in newsletters and magazines, such as Ms. They received over 600 photographs from more than 100 women. They held their first production meeting in March of $1980 .{ }^{203}$ The success of both Ovular I and the call for photographs resulted in Ovular II in the summer of 1980. These Ovulars continued into the mid-eighties, and spurred many other creative feminist productions both within rural southern Oregon and in cities throughout the United States. ${ }^{204}$

\footnotetext{
203 The Blatant Image, (1981), 2.

204 Tee A. Corinne, "Nourturing Creativity in Southern Oregon Women's Communities" in Community Herstories: Living in Southern Oregon. Pink Cop, ca. 1990, n.p.
} 


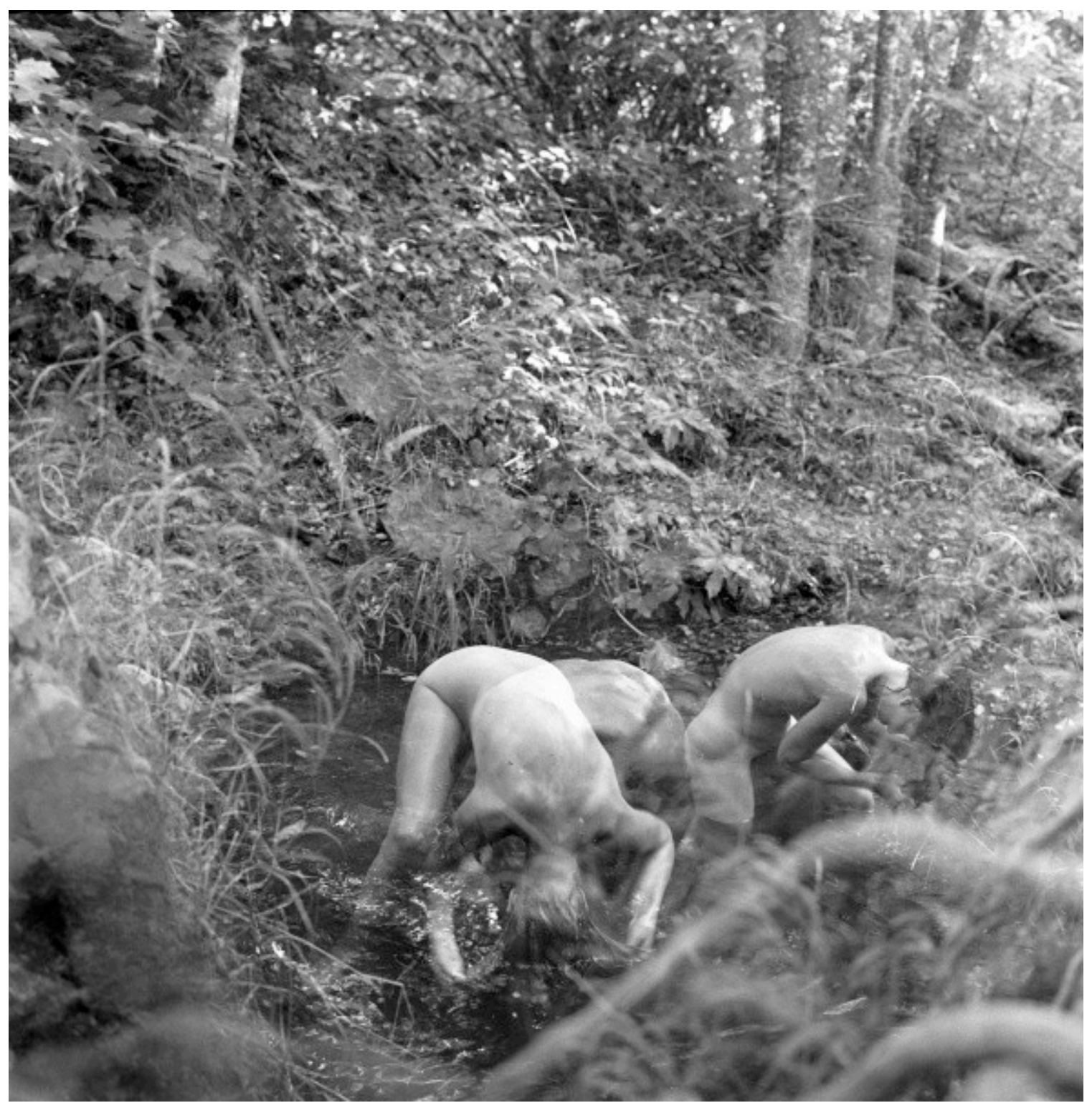

Figure 6: Ovular 1, Clytia, Tee 1979, http://oregondigital.org/u?/comm,198, University of Oregon Libraries, Ruth Mountaingrove Photographs, Coll. 309

In 1991 the first annual Dyke Art Camp was held at Rootworks. The Dyke Art

Camp grew out of an idea that came from several southern Oregon artists who had been 
members of the Artist's Group, including Sierra Lonepine Briano and Jemma Crae. It eventually moved to Steppingwoods, and then was discontinued after fourteen years. ${ }^{205}$

Just as the practicalities of life, the acquisition of food, shelter, and companionship, were questioned and re-constructed, so too were ideas around material culture. The women interviewed questioned their beliefs around who and what makes art. They worked to remove the myth that one had to be educated, gifted, and wealthy or have wealthy patrons to express oneself through artistic endeavors. Perhaps the clearest example of this ideological shift came from Billie Miracle. She was born in Wisconsin, and her family instilled in her the belief that she had to choose a profession that was practical, one that would support her should anything happen to her husband or marriage. ${ }^{206}$ Part of her personal transformation, within the lesbian land community and WomanShare Collective, has been reconciling the producer-consumer nature of art with her creative nature:

And my personal goal was to do art too. And to do art that was not hierarchical. It wasn't elitist. And I still have that. That's the hardest thing for me around art, in my whole lifetime of being an artist--trying to fit myself in, because I come from a real working-class background. The art world is so middle class and upper-class, and so based in monetary value of things, so it's always been challenging for me. I was an art teacher for a while too--in the college where I teach now, and it's just--I didn't feel comfortable in that role. I still teach art. I work with students that are coming back to school, that have gone to college or are just coming to college after years of working in the home or working regular jobs. I still teach art to them, but that feels more like my people. Creativity is not the sole domain of the upper-class. ${ }^{207}$

\footnotetext{
205 See Jemma Crae, interview with author, (13 January 2011), 21-22.

206 Billie Miracle, interview with author, (6 May 2011), 3-7, 13-14.

207 Billie Miracle, interview with author, (6 May 2011), 14.
} 
The popularity of the 1976 publication of WomanShare Collective's book, Country Lesbians, the Story of the WomanShare Collective and WomanSpirit magazine attracted more women, from all over the world, to southern Oregon throughout the 1980s. ${ }^{208}$

\section{Global Impact}

"Creativity is not the sole domain of the upper-class."209 This sentence reveals both the rejection of an ideology that places economics and culture within a hierarchy of upper- lower and dominant- subservient, and the reclaiming or liberation of the materials within it. Rejection, reconstruction, and reclamation is prevalent throughout both the interviews and material culture of the southern Oregon lesbian land communities and reflects a simultaneous increase in the visibility of women, feminists, and lesbians within various segments of the art world. Most of these artists critiqued and addressed those same ideas of ownership, consumption, sexuality, patriarchy, and power. ${ }^{210}$ Just as the women artists within the lesbian land communities were claiming a safe space in the country, urban women artists were also creating space in cities. There were numerous collective spaces created by and for women artists as early as 1972.211

Much of the art produced by women within urban America during this time period shifted away from the earlier performance body art of women such as Yoko Ono

\footnotetext{
208 Sue, Nelly, Dian, Carol, Billie, Country Lesbians: The Story of the WomanShare Collective (Grants Pass, Oregon: WomanShare Books, 1976).

209 Billie Miracle, interview with author, (6 May 2011), 14.

210 See, for example, Harmony Hammond, Lesbian Art in America: A Contemporary History (New York: Rizzoli Publications International, 2000), 8-57. And Hal Foster, Art Since 1900: Modernism, Antimodernism, Postmodernism (New York: Thames \& Hudson, 2004), 17-20 and 580-582.

211 AIR (Artist in Residence), New York, NY of which Harmony Hammond was a founding member began in 1972. See Hammond, 12. As well as Foster, 570.
} 
and Carol Schneeman, and reclaimed traditional women's craft, and utilizing it in bold new ways, such as Judy Chicago's The Dinner Party (1974-9) and Faith Ringgold's story quilts. $^{212}$ The women in the lesbian land communities made similar critiques, and also addressed the production and ownership of the work. Whereas, many feminist artists critiqued ownership in terms of the point of creation, the most famous example being Sherrie Levine's challenge through the appropriation and alteration of Edward Weston's 1925 nude photographs of his son, others critiqued ownership in terms of the viewer, creating work for an exclusively separatist audience or simply getting rid of the distinction between creator and audience altogether. ${ }^{213}$

The southern Oregon lesbian land community had a very fluid population during the 1970s and 1980s. Women came and went from the lands to the city and vice versa, with the majority of visitors coming to the lands in the more temperate summers. Much of the art created on the lands included constructions, sculptures, paintings, and photographs of women's bodies, alone or with others, and often in settings in nature. The bodies often celebrated physical difference, with positive representations of women of varying abilities, sizes, shapes, and colors. ${ }^{214}$ Many of these works became a part of a group journal, exhibit, or performance for an exclusively female audience. Tee A. Corinne described the process as addressing questions, such as: "How has the women's movement changed the way we see? What kinds of photos are being produced and published now that haven't been seen before? What are the realities of our shapes and our

\footnotetext{
212 Foster, 566-572.

${ }^{213}$ Foster, 580. For examples of distinction between audience and creator, see Billie Miracle, interview with author (6 May 2011), 18.

214 Hammond, 80-83. See also Corinne, "The Ovulars and The Blatant Image Postscript (only a small part of the story)," in Community Herstories: Living in southern Oregon, unnumbered pages.
} 
lives? What are the differences between the ways men have pictured women and the ways we see ourselves?"215

The community worked together to develop, print, publish, record, and publicize the work of feminist photographers. The first issue of The Blatant Image (1981) includes early work by Carrie Mae Weems and a Photoessay, "Documenting Rituals: What a Modern Day Problem!," by Mary Beth Edelson. ${ }^{216}$ Thus the relationship between the urban and rural communities was one of mutual sharing. That sharing crossed oceans and continents, as the magazine published the work of women throughout the world. In one particularly interesting article that juxtaposed the British with the American ideas of feminist photography, Jana Birchum explained how the work itself was important politically and culturally, "That we are constructing reality through the images we make." 217

The significance of this cultural movement to which the southern Oregon lesbian lands contributed could best be described as an opening of possibilities. The women involved in this culture creation made concrete what had been previously unseen. Lesbian feminists could now see themselves in literature, music, paintings, and photographs. There was a language with which they could communicate. While discussing the phenomenon of women's music, Tangren Alexander explained, "It just glimpsed that whole possibility of how there could actually be a culture that actually acknowledged who we were, and what we understood. It was huge."218 Similarly, artist Harmony Hammond

215 Corinne, "Nourturing Creativity in Southern Oregon Women's Communities," in Community Herstories: Living in Southern Oregon, unnumbered pages.

216 See The Blatant Image: A Magazine of Feminist Photography, no. 1, (1981).

${ }^{217}$ Jana Birchum, "British Feminist Photography," The Blatant Image, no. 3 (1983), 17.

218 Tangren Alexander, interview with author (13 February 2011), 27. 
wrote, "Lesbian-generated representations in movement journals gave us empowering images of ourselves that we never had before."219

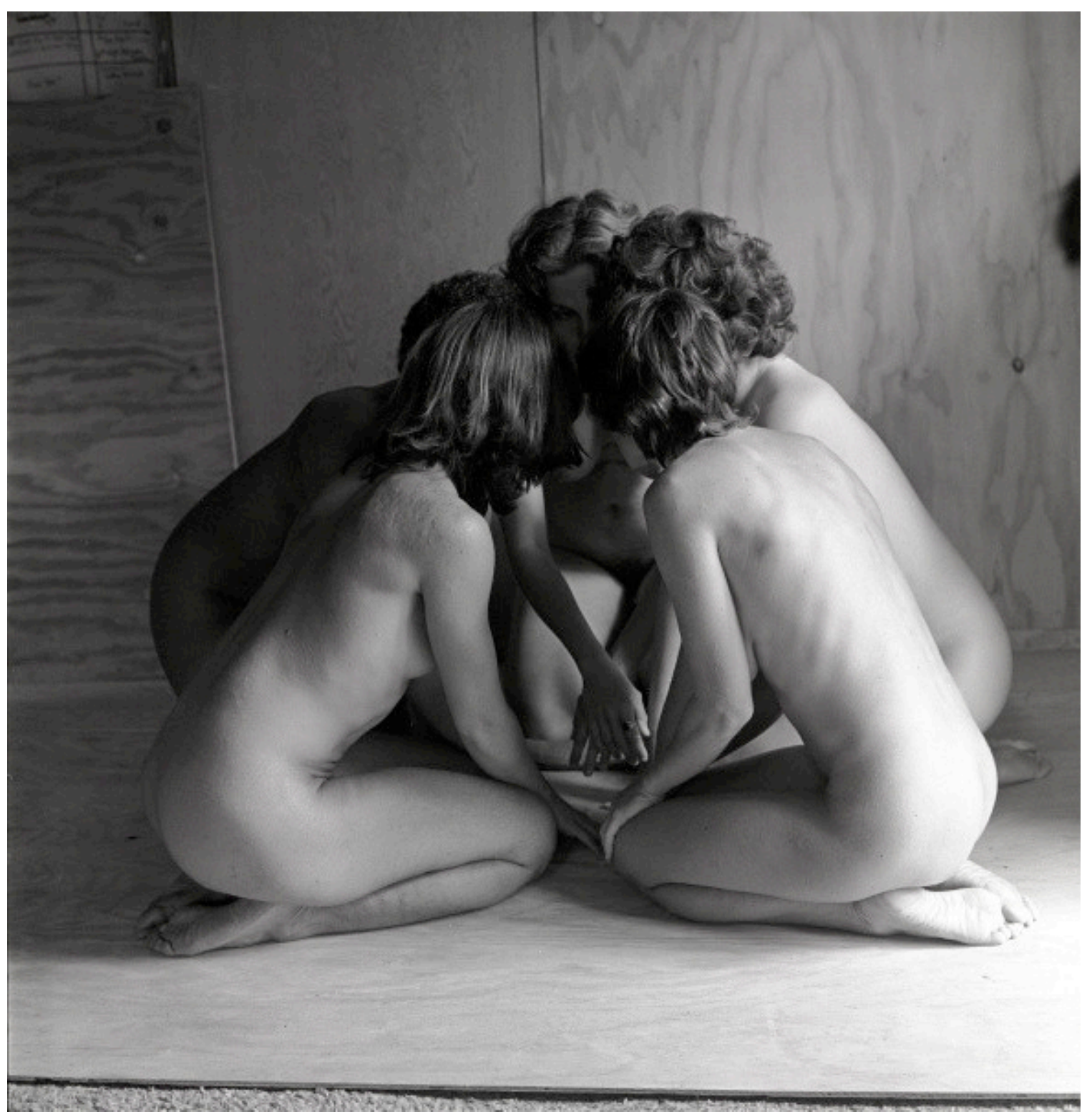

Figure 7: Ovular 2, Rootworks 1980, http://oregondigital.org/u?/comm,230. University of Oregon Libraries, Ruth Mountaingrove Photographs, Coll. 309

219 Hammond, 20. 
These powerful images captured on the pages of publications, such as The Blatant

Image and WomanSpirit, had a global reach. Jean Mountaingrove, one of the publishers,

listed the contributors to the magazine:

Yes. I'm trying to find--it was amazing, even for me to read it. (flipping through the index) Okay, women in Alaska, Native American women, Black women, from Australia, Central America, England, Denmark, Egypt, France, Germany, Greece, Hawaii, Ireland, Japan, Italy, Malta--coming home to Malta, Mexico, New Zealand, Polynesia--almost anything you could imagine! Thailand, Vietnam. ${ }^{220}$

This exchange and global impact can partially be explained by their understanding of the interconnection and global networks to which they belonged. In addition to the obvious connection with $M s$. magazine's readership, the lines of communication between women included an estimated seventy-five women's bookstores in North America, not to mention other feminist businesses including art galleries, coffeehouses, and nonprofits. ${ }^{221}$

The women of Rootworks worked in collaboration with women photographers, who had traveled from all over the world to the southern Oregon lesbian land for the

${ }^{220}$ Jean Mountaingrove, interview with author (25 October 2010), 23.

${ }^{221}$ Rachel Corbett, "Women's Bookstores Dwindle to Stalwart Few," Women's News (August 15, 2005), http://womensenews.org/story/books/050815/womens-bookstores-dwindle-stalwartfew\#.UX8HOnHT1bw Accessed on April 28, 2013. As well as K. A. Hogan, (2006). Reading at feminist bookstores: Women's literature, women's studies, and the feminist bookstore network. The University of Texas at Austin). ProQuest Dissertations and Theses, 359-359 p. Retrieved from http://search.proquest.com/docview/304984076?accountid=13265. (304984076) And Kristen A. Hogan, "Defining Our Own Context: The Past and Future of Feminist Bookstores," Thirdspace: A Fournal of Feminist Theory and Culture Vol. 2, Issue 2 (March 2003), http://www.thirdspace.ca/journal/article/view/hogan/114 Accessed on April 28, 2013. 
Ovulars, and published the first issue of The Blatant Image in 1981. Over the course of three years this collaboration, though not with all of the same women each year, continued publication. While it is impossible to document or verify the totality of its impact on individual photographers or collaborators or readers, we do know that in one specific instance The Blatant Image inspired an offshoot publication in the San Francisco Bay Area. CounterVision: a photo-journal on cultural diversity in the community of women was published by a group of women from the Bay Area who had previously participated in the Ovulars. CounterVision began publication in 1982.222 The southern Oregon lesbian land community provided the time and space necessary for women to learn and develop skills and ideas, which they were then able to take back with them to San Francisco and other places.

All of these collaborations, publications, processes and exercises in culture creation built up a reputation for the lesbian land communities of southern Oregon. That reputation and the culture it circulated throughout the wider lesbian community in the 1970 s and 1980s changed lives. While there is no absolute way to calculate or quantify that impact, we can know the quality of it to specific lives. This quality is visible in the lives of those individuals it impacted, and its continuation with the current generation of lesbian feminist identified women. For example, the We'Moon datebook has been in continual publication since its inception in 1980, and in 2012 sold 49,880 copies of its 2013 edition to at least a dozen countries. The current editorial staff includes women who

222 The Blatant Image (1982), 2. See also Michele Leber, ed. Women In Libraries, Neweletter of the ALA/SRRT Feminist Task Force 12, no. 1 (September 1982): 5. This newsletter is also available electronically: http://libr.org/ftf/WIL\%20Archives/v12n1\%20sep1982.pdf (accessed December 18, 2011). 
have moved to or purchased land near the existing southern Oregon lesbian lands, and women who are younger than their women's land movement predecessors. ${ }^{223}$

The lesbian lands in general and the southern Oregon lesbian lands specifically added some rural flavoring into an overwhelmingly urban pot of lesbian culture. The lands provided a place for lesbians to gather outside metropolitan urban centers, such as Chicago, Copenhagen, London, New York, and Paris. In these rural safe spaces, between 1974 and 1985, women from all over came together to create photographs, poetry, song, ritual, performances, and art. They shared materials, knowledge, technical skill, and inspiration. They worked together to publicize their creative endeavors, and shared those publications with lesbian feminists across the globe.

${ }^{223}$ Sue Burns, We'Moon editorial staff, email communication with author, April 29, 2013. 


\section{Chapter 4: Safekeeping Women's Land}

I had decided I had visited several communes--this was 1970--and on the way back from Philadelphia I had visited several communes, looking for a community, and I didn't really find anything that fit very well. When I got to California and my mother put some pressure on me to do something, I heard of a place up in Oregon called Mountain Grove; it's just north of here, off exit 83, and it was just getting started. It was on a mountainside with a lot of trees, and a lot of young people. The man who had started it was in his sixties and all of the fellas and women on the land were in their twenties and thirties. When I came I was in my-I was forty-five, I guess, at that time--1970. I walked around on the land and sat by the creek. I decided this was where we were going to stay.

--Jean Mountaingrove 224

The future of the women's lands in southern Oregon is dependent upon the continuation of a community of women with the desire to sustain a long-term commitment to the land and the community, as well as the existing community's willingness to accept a new generation of women and adapt to meet their needs. Some of these needs involve financing a clean water source and solar energy panels, but others are simply allowing the women who live there to make their own decisions and mistakes regarding where to build a cabin or when to remove a tree.

While some of the women's lands of southern Oregon have met these challenges, others have not been so fortunate. As of this writing, there are many lands without younger women ready to take over for the aging populations. Some lands, such as OWL Farm, as of 2011 had no one living there year round. Steppingwoods, Fly Away Home, and OWL Farm have been without the next generation of women for several years.

${ }^{224}$ Jean Mountaingrove, interview with author (23 September 2010), 9-10. 
Those women who were interviewed are concerned about the future of the lands, and question the possible causes of their predicament.

Many of the women, who have spent any time at all on the southern Oregon women's land as visitors, residents, or members of the community, have since left for a variety of reasons. ${ }^{225} \mathrm{~A}$ small but significant number of the founding members remain on or near the lands they helped create. These elders have served as guardians, protectors, and promoters of lands that belong to women, in the largest sense. The women interviewed, see themselves as the keepers of a sacred and valuable space, which they hope will one day soon experience revitalization with a new population of women.

Women within the community value women's land or lesbian land for all of the reasons discussed within this thesis. It is seen as a safe space for women to experience and explore themselves and their relationships with others. It is land. It is nature, with which most of the women interviewed have expressed a deep personal and spiritual connection. As Tangren Alexander so eloquently said, "It really feels, when I go to Fly Away Home, like I've left the United States of America. I'm somewhere else. I'm in another world where we do things differently, and where different rules apply."226 Billie Miracle, founding member of WomanShare Collective explained:

And the land is so important. That having access to open natural places is so important for women, and for everyone really, but--the skills that you didn't think you could have, you can get, and especially by helping each other. Doing it together. Doing it in community. ${ }^{227}$

\footnotetext{
225 As Bethroot explained in "Landed" Sinister Wisdom 63 (2004).

226 Tangren Alexander, interview with author (13 February 2011), 20.

227 Billie Miracle, interview with author (6 May 2011), 27.
} 
Zarod Rominski, one of the early members of Cabbage Lane waxed poetic while

recalling the experience of living on the land in southern Oregon:

It was one of the most wonderful times of my life, and it was that because I lived so close to the Earth. For instance, we would go up and fix our water source. We knew where our water came from. We not only knew it, we were there. We repaired the reservoir and pipeline. We cut our own wood for our winter fires, and we built our cabins. We hauled truckloads of manure in, to make a garden space. There was just something so invigorating about living that close to the land, and to nature. ${ }^{228}$

After leaving Cabbage Lane in the eighties, Zarod Rominski went on to Seattle for work, graduate school, and travelled with a Seattle women's delegation to China for the U.N. International Women's Conference. ${ }^{229}$ She later returned to Portland, and has since worked with the community to revitalize Cabbage Lane. Her reasons for returning reveal a deep connection to women's land:

Yeah, but then after a while I really started missing the women in southern Oregon. I made such deep and strong connections with Bethroot and La Rosa and Cabbage Lane and the culture, you know, the culture of-just the whole culture of women-centered, woman-caring, the song circles, the writing, the sharing of writing--all of those things that we created, and that continue to this day. I just wanted to be closer to it all, and be a part of it again. ${ }^{230}$

\footnotetext{
228 Zarod Rominski, interview with author (13 May 2011), 40.

229 September 1995, Fourth World Conference on Women. For details on the conference, see (http://www.un.org/womenwatch/daw/beijing/fwcwn.html) the United Nations Entity for Gender Equality and the Empowerment of Women, UN Women. See also: Nardini, Jennifer, "Women's Conference Delegates Come Back With Ideas, Insights," The Daily of the University of Washington: the University of Washington Student Newspaper, October 19,1995. http:/ / dailyuw.com/news/1995/oct/19/womensconference-delegates-come-back-with-ideas/ (accessed 08/08/2012).

230 Zarod Rominski, interview with author (13 May 2011), 26.
} 
Zarod Rominski, along with a number of other women who had been a part of the initial creation of women's land in southern Oregon and since moved to urban areas such as Portland, continue to visit the lands, participate in decision making processes, and contribute time and money to the survival of women's land in southern Oregon. Part of that survival has required that steps be taken to ensure that the land remains women's land far into the future, after the founding members have died. While they acknowledge that they have very little control over what decisions are made after their deaths, there are precautionary steps that they can and have taken. These steps involve the establishment of land trusts, covenants, nonprofits with boards, and wills. Evidence of this future planning stretches back to the early years in the land development.

The initial land purchases in the 1970s depended on money and access to money. Some of the women who were able to purchase lands outright were women of means, some purchased the land with a group of women or women and men, and still others gained access to funds through divorce settlements or inheritances. All of these methods required that named individuals were on the land deeds, and therefore individual women were the concrete owners of the land. This ownership situation did not always sit well with the owners themselves or the women joining them in community.

After the workshop at WomanShare, as well as numerous CR meetings and land meetings, there was a shift in thinking, a movement toward trying to make some lands more accessible to women without means. This movement resulted in OWL Farm and the Oregon Women's Land Trust (OWL), which governs it. Since this time, as the founders and deed holders age, some of them have began to make plans to will lands to 
nonprofits. ${ }^{231}$ Nonprofits, such as Rootworks, Cabbage Lane and OWL Farm are managed by boards, and the women $\mathrm{n}$ the boards have final decision making power regarding land use and residency. ${ }^{232}$

In addition to the transition from private ownership to land trusts, the lands have constantly undergone changes in residence. Many of the more private lands, such as Rainbows End, Steppingwoods, and Fly Away Home have been able to maintain a steady and constant population, but the more open lands have not. Then there is the issue of maintaining these lands as the women age. In 2009 Jean Mountaingrove, one of the founders of Rootworks, moved off the land and into the town of Wolf Creek. At age eighty-four, she acknowledged her physical inability to continue life on the land. ${ }^{233}$ Later in the interview this acknowledgement resurfaced as part of a critique of mainstream culture and its media:

Old has a very negative attitude in our culture. What I see on TV, read in Oprah--which I'm not going to subscribe to--it's all about being beautiful, fashionable, all the things you can take so you won't have a wrinkle, how embarrassing it is if someone asks how old you are--you're not supposed to do that--and all this sort of thing.

I think that my 'stop sign' for living at Rootworks was very accurate. It doesn't suit my health and my physical abilities now. For one thing the road isn't very easy, but also just a lot of other things are more difficult. I can't do the gardening that I used to do. I can't climb up on the roof and fix things like I used to, and the community is different. 234

\footnotetext{
231 See for example: Jemma Crae, interview with author (13 January 2011), 33-35. Dana MacDonald, interview with author (13 January 2011), 20. Zarod Rominski, interview with author (13 May 2011), 39-40. 232 See for example: Jean Mountaingrove, interview with author (23 September 2010), 18-24. Zarod Rominski, interview with author (13 May 2011), 39-40.

${ }^{233}$ Jean Mountaingrove, interview with author (23 September 2010), 25.

${ }^{234}$ Jean Mountaingrove, interview with author (23 September 2010), 30.
} 
Because the lesbian land community of the 1970s and 1980s had more and younger members as compared to 2010, an older woman might have had a better chance of surviving on the land. In 2009, the community had changed, and there were not enough young women to care for the elders. In 2010, Jean continued to question mainstream society, and work within a community she can no longer physically belong.

Wolf Creek is still relatively close to Rootworks, and Jean continues to serve as both a resource and guide, "I still have some affect there. I'm still a treasurer on the board, but I really feel that it is time for the younger generation to adapt it to what their needs are."235 Similarly, as a relatively new member of the community of the small town of Wolf Creek, she is able to find value and place in relation to her daughter who has lived there for over thirty years. Interestingly enough, within the community of Wolf Creek, Jean saw her sexual identity as more of a barrier to community engagement than her age: ${ }^{236}$

Some people in Wolf Creek now know me from many many years ago--I do not speak of being a lesbian. I don't brag about it or promote it. I'm not sure what response I would get, but I think that lesbian is only part who I am and if I be who I am, which is generally kind and welcoming and participating. I'm now on the board of the local nursery school here called Parent's Center, and I go to the business meetings of the community once a month. And I'm now helping the manager of a local business who is the editor of the little local newspaper. I work with him on proofing it. And so I feel that I'm comfortable. ${ }^{237}$

\footnotetext{
${ }^{235}$ Jean Mountaingrove, interview with author (23 September 2010), 25.

${ }^{236}$ Jean Mountaingrove, interview with author (25 October 2010), 17.

${ }^{237}$ Jean Mountaingrove, interview with author (25 October 2010), 16-17.
} 
Jean Mountaingrove has had to make choices within this new community not unlike the choices she had to make when she began Rootworks. While she was unable to physically do the same activities as she was in her youth, she contributed her knowledge and experience in ways that she was able. Both communities continued to value these contributions. Jean's dedication to the preservation and continuation of women's land was evident in her participation on boards and in the capacity of advisor and mentor. However, she also acknowledged that it is time for her to let go of Rootworks. ${ }^{238}$ Dana MacDonald, of Steppingwoods, similarly acknowledges the need to let go and the need for young women, when she summed up the community's collective concern:

It took a lot of effort to develop this land before I came here. All the houses, all the structures, all the roads, the infrastructures, and it takes a lot to keep it up, so we're looking for other women to come be here after we die, which a lot of women are looking for, on the lands. Whether they be OWL or Cabbage Lane or here, I mean different lands have different specifics that they want...Right now it's a part of a foundation, it's a part of that OWL--Oregon Women's Land Trust--is where this land is going, and we're in the throes of getting more of the specifics down, so that this land will be protected, and especially the trees. ${ }^{239}$

The concern that Dana expressed reveals two important lesbian land principles:

1. That the land and all of its inhabitants should be protected. This includes women, trees, resources, and wildlife. 2. The continued critique of ownership.

Zarod Rominski also expressed her concern for the trees, wildlife, and natural resources as a part of her concern for the future of women's land:

${ }^{238}$ Jean Mountaingrove, interview with author ( 23 September 2010), 25.

${ }^{239}$ Dana MacDonald, interview with author (13 January 2011), 20. 
I guess my main hope is that the land continues as women's land, and that that is a protection for women and for the trees. I'm pretty committed to preserving trees, and allowing trees to grow into second generation old growth, so that's my main thing. It's that it continue as a space for women and for that ecology. ${ }^{240}$

The inclusion of the land and all its inhabitants as part of the community, as expressed in previous chapters, was often expressed in the interviews in terms of protection and ownership. On the one hand, ownership was eschewed as elitist and patriarchal while simultaneously ownership was important to the continuity of women's land as safe space and its protection from what could be described as patriarchal profit motives or an environmental concern that critiques the economic value that the timber industry places on the extraction of profit from nature in southern Oregon.

This ownership, as expressed by those interviewed, is not personal ownership but an ownership that extends to like-minded women the world over. Jemma Crae avoided the ownership language altogether, choosing instead to refer to this generational transition as seeing it "stay in women's hands"241 and making "sure that this land is going to be in women's hands after I go."242 The repetitive reference to "hands" most likely serves as a metaphor for control. Writers and speakers alike often use "hands" or related words to describe when things are out of control or when things get "out of hand." Similarly to take control of things might be referenced as "handling it" or having it "in

240 Zarod Rominski, interview with author (13 May 2011), 31.

${ }^{241}$ Jemma Crae, interview with author (13 January 2011), 33.

${ }^{242}$ Jemma Crae, interview with author (13 January 2011), 34. 
hand." 243 While Jemma Crae was not, in the strictest sense of the word, a separatist, she expressed a connection to and identified the importance of continuing to maintain a safe space for women:

I'd like to leave it to some organization or someplace that would care for the land, and continue the practice of women's land. Little industries could utilize this land, you know, there could be meditation retreats or there could be artist's workshops or anything like that. That's what I would like to see this become. I'm in the process of working with a group of women and my financial planner to figure out how to make this happen, because I have enough money that a big chunk of money can go along with this land for maintenance, and I feel like if that's in place, then it would be easier for it not to be lost. As I'm getting to be sixty-eight in February, I want to be able to make sure that this land is going to be in women's hands after I go. ${ }^{244}$

All of the narrators articulated a concern for the future of women's lands, especially in terms of their own mortality and finding younger women to take their place.

Rootworks, WomanShare, Rainbow's End, and Cabbage Lane currently have younger residents.

At the time of the interviews, 2010-2011, there were two women living at Rootworks, Bree and Sailor. According to Jean Mountaingrove, this transition wasn't going as smoothly as she had hoped. There were some generational differences and unmet expectations on both sides. Jean explained:

She is thirty-one, and Bree is twenty-five. They are growing up in a different world. A lot of it is the same, unfortunately. Women's needs

${ }^{243}$ These and other idioms are readily available in any print or online dictionary. For example see: http://idioms.thefreedictionary.com/

${ }^{244}$ Jemma Crae, interview with author (13 January 2011), 34. 
are different now than they were then. And I--another one of my jokes-I can see straight ahead, but I can't see around the corner. So I can see straight ahead with Bree and Sailor doing really good things there at Rootworks. I don't know what the long-range effect is going to be. One of my concerns is with the emphasis with young women, which is totally logical, on seeing the NOW--how things are right now, and dealing with those. They don't look at the long-term results, because they haven't been in the long term. That's what's called getting wise, when you have lots of experience and you learn from them. So the young women, it seems to me --the ones I know, and I don't know very many, because I live in a separate realm. They are very kind to me. They are thoughtful of me, but they really --are not really interested in me, in my life, my view of things. When I would use what I have learned over the years, and talk with them about it, they think it's inappropriate. The future will be different. Now I know that if you leave things, wooden things, outside all winter, that they will make it through the spring, but the next year and the next year and the next year the won't. These are the long-range effects. So long-range is not an important part of young people's perspective. I don't know that ours' were long-range when we started out in the seventies, but we survived (smiles). ${ }^{245}$

Jean felt that Bree and Sailor had stronger connections with Gypsy Cafe, which was a privately owned land in Sunny Valley with younger women residents, than with the larger women's land community of southern Oregon. However, even though Gypsy Cafe and its residents do not personally identify as women's land, there is an undeniable similarity and connection between Gypsy Cafe and the women's land community. As of 2010, there is a We'Moon office at Gypsy Cafe, and some of the residents help with the production and coordination of the datebook. ${ }^{246}$

\footnotetext{
${ }^{245}$ Jean Mountaingrove, interview with author (23 September 2010), 30-31.

${ }^{246}$ Jean Mountaingrove, interview with author (25 October 2010), 19. See also Tangren Alexander, interview with author (12 November 2010), 30. All of the women interviewed spoke of Barb at Gypsy Cafe with deep admiration and respect. I tried to arrange an interview with Barb, but received no response. In one informal and social in-person meeting, Barb made it clear that her property was not women's land, and yet her connection to the community is undeniable. It is the location of one of the We'Moon Calendar/Mother Tongue Ink offices.
} 
In one interview Jean Mountaingrove drew a comparison between present day Gypsy Cafe and the Rootworks of the 1970s, both located in Sunny Valley, Oregon, "we made some income doing the magazine and they make income doing the We'Moon. And I think they have a--well, in a way that was what it was like when we had WomanSpirit. It brought in a lot of attention from a lot of places--some income, and very good. Yeah, I just wish that it would happen for Rootworks."247

Perhaps because of the book Country Lesbians and the intentional control over residents and land decisions WomanShare has remained continually occupied. At times, Billie Miracle was the only resident, later moving onto an adjacent land. At the time of the interview, there were only a couple of women living there, and plenty of seasonal visitors. $^{248}$

Rainbow's End has maintained a relatively steady number of residents over the years. Although I was unable to arrange an interview with Francis Etherington, other women have consistently described Rainbow's End as a different sort of collective. In her 2003 dissertation, Catherine B. Kleiner described Rainbow's End as more private than other collectives, saying, and "What the women do in their own houses is considered their own business. They rarely have meetings as a collective and have very few rules. Some land lesbians say the key to the longevity of the collective is the premium residents place on privacy."249 Unlike Rootworks, Cabbage Lane, and OWL Farm, Rainbow's End is organized as a mutual benefit nonprofit, which means that it is only responsible for the

\footnotetext{
${ }^{247}$ Jean Mountaingrove, interview with author (25 October 2010), 19.

248 Billie Miracle, interview with author (6 May 2011), 17. For a summary of some of the earlier transitions see Gagehabib, 38.

249 Kleiner, 115.
} 
benefit of its own members, who are the residents. The board is made entirely of residents, and they make decisions for their own benefit not the public. ${ }^{250}$

In order to ensure their survival, the women's lands in southern Oregon must be able to physically, legally, and psychologically transfer control over the lands and community to the next generation. Rootworks, Cabbage Lane, and OWL Farm are all set up as nonprofits. ${ }^{251}$ As of 2012, Cabbage Lane had three residents. These newest residents, under the guidance and supervision of elders like Zarod Rominski, are gradually making the same transition as Rootworks, but with slightly different results, most of which is due to the commitment and dedication of all parties involved. Zarod described the transition as a process of letting go:

I think I'm pretty attached to what it was when I was there, you know, land in which three or four or five women lived in these little tiny cabins scattered around. We shared this big garden and we lived very close to the land, no amenities, no power, running water to one faucet, but I think times have changed. I'm not sure that kind of thing is possible or at all desirable. I mean, women have not chosen to live there. Those cabins have gone to ruin, basically, because women have not chosen to live there. Now there's some women living on the land. There are three women living on the land who are pretty committed to being there, and wanting to build a new cabin. A couple of them want to build a new cabin. A third one wants to renovate an old cabin. And it's hard to--you know, what I see is I see the possibility of a new generation of women carrying it forth, and I feel really good about that. I feel like, you know, I'm going to die, and I'm also--I can't be down there. I don't live there. I'm not going to move there. I can't be down there all of the time, so I want other women to take it over, but I also have my feelings about how they do it! (laughing) Those things mostly have to do with wanting it to continue to be women's land, and not just become somebody's private land. Or even if they don't see it that way, that other women experience it as a place that they're welcome, and that there's a

\footnotetext{
250 Author's phone conversation with Bethroot Gwynn, April 28, 2013. See also as documented in the State database, accessed on 29 April 2013, <https://data.oregon.gov/Business/Active-NonprofitCorporations/8kyv-b2kw> Cabbage Lane and Rootworks are public benefit nonprofits, and Rainbows End is a mutual benefit nonprofit.

${ }^{251}$ Zarod Rominski, interview with author, (13 May 2011), 39.
} 
place for them. There's somewhere for them to camp or gather as a group of women. ${ }^{252}$

What Zarod described in the above quotation is the process of letting go of control over an idea and creation, so that it can continue to flourish in the future, but tempered by the desire to educate and guide the next generation with one's own knowledge and experience. Both the old and the new generations experience this in different ways, and what's interesting is how Zarod's own experience with her community work at Outside In in Portland has in a way prepared her for this transition. Since 1996, Zarod has served as the Associate Executive Director for Outside In, a Portland non-profit with a mission to "help homeless youth and other marginalized people move towards improved health and self-sufficiency." ${ }^{253}$ Her work at Outside In has given her opportunities to develop relationships with a diverse youth population, including young people who identify as queer and/or transgender. It seems from her own statement, that she recognizes some of her attachment to the past as unrealistic for the future.

Jemma Crae voiced her concerns about Steppingwoods, located several miles outside of Roseburg, by saying:

What's going to happen to this land? For me, I'd like to see it stay in women's hands. I'd like to see some kind of purpose for this land, and I want to see the forest maintained and not cut down. I'm trying to make this forest into an old growth forest, and I've been doing some selective thinning, helping that out. I don't have anybody to will the land to. I had a dream the other night that a woman came up, and I made friends with her and I donated the land to her. ${ }^{254}$

\footnotetext{
252 Zarod Rominski, interview with author (13 May 2011), 32.

253 See Outside In website: http://www.outsidein.org/about.htm (accessed on March 12, 2013).

${ }^{254}$ Jemma Crae, interview with author (13 January 2011), 33-34.
} 
Dana MacDonald, the other resident of Steppingwoods, also expressed hope for the future of the land, explaining that it would be easy for someone to start some sort of cottage industry, possibly internet-based, and working together they could make life easy for everyone on the land. ${ }^{255}$

As of this writing there are two residents of Fly Away Home, Bethroot and Madrone. Bethroot Gwynn has been involved with the maintenance and future of OWL Farm, and in 2011 described its situation:

There's a woman who is being paid a stipend every month for right now. We don't have enough money for it to last very long. She is a part-time caretaker, so she has a little trailer there, and she goes and is doing a lot of--especially the grounds--maintenance, but no one is living there right now. No one's been living there full-time since a year ago this past November. It's been a long time since it's been anything like a community of women living there. ${ }^{256}$

Yet again, Bethroot also has the same concerns as other elders regarding the

future of the land--where are the younger women? Who has it in themselves to take on this work and reap the rewards? Like her contemporaries, she too has a vision:

So the hope and the dream is that some day there will be women who come along who will have the energy and commitment and dare I say it--resources to be able to take it on. And there would be, I think, some other resources that could be made available. There could be grants written, and so forth and so on, but of course it also is land that was created so that women who did not have access to wealth could be on land. So it's a thirty-five year old promise that in

255 Dana MacDonald, interview with author (13 January 2011), 25.

256 Bethroot Gwynn, interview with author (27 January 2011), 42. 
some years, in some decades, has had some fulfillment, and in many decades the promise has not been fulfilled. 257

The question on many of the women's minds, women who began this lesbian land community in the 1970s, has been why? Why haven't the women come in the numbers that they imagined? Why are they not coming in droves now? For some the question evokes answers that include the hardships or inconveniences of specific lands. There aren't jobs nearby. Some of the lands do not have electricity or Internet access. There is also the deeper philosophical divide that some have described in terms of waves, second wave and third wave feminists. Still others see a dwindling in the popularity of feminist political engagement in favor of a queer identity that embraces a continuum of gender identities or at least places less emphasis on gender as an identity to embrace.

Furthermore, not many younger lesbians know that these lands exist.

Why are they not coming in droves now? In Bethroot Gwynn's interview, her attempt to answer this question reveals more about the divide between generations of women:

My sense of the times and how the times have changed is that younger women don't seem to have much appetite for creating separate spaces--that there is, in fact, if I look at the world of insta-communication and social-networking, there's a great hunger to be connected to the wide world, and those communities are happening willy-nilly everyday, you know, on those little devices that people carry around. But you know, we wanted to be connected. We wanted to be connected with each other and to make a new--to create a new--path. Now, as to whether anybody's going to come along down that path--follow it along-then I guess that's a real question. And I don't see that very many young women seem to have appetite for--I started to say country living, but there's a huge number

257 Bethroot Gwynn, interview with author (27 January 2011), 44. 
of women involved in the forest protest movement, and in the environmental movement, women who are wanting to grow food, you know, there is. On the other hand, there is ferment that has to do with back-to-the-land values, so here we are with all of these acres--eleven hundred acres of women's land in southern Oregon, counting the five hundred acres that is Whispering Oaks, that's owned by Liz Crain. ${ }^{258}$

Perhaps the key to answering the larger question of why haven't more young women joined the lesbian land community in southern Oregon lies in the first sentence of Bethroot's response, "My sense of the times and how the times have changed is that younger women don't seem to have much appetite for creating separate spaces--..." or in her acknowledgment that modern technology has enabled women to connect, build coalitions, and develop a different type of community. ${ }^{259}$ However, as Bethroot acknowledged, there has been a growing number of young people moving to rural areas, some of who have joined existing communities. Therefore another possibility is that the younger generation needs the space to make their own decisions, their own mistakes, and develop their own community in the face of an existing lesbian land community that is unable to let go of control.

For example, later in the interview, Bethroot described how this lack of interest has resulted in the cancellation of the annual U.S. Land Dyke Gathering while simultaneously acknowledging that there are young women on land outside of these older communities:

\footnotetext{
258 Bethroot Gwynn, interview with author (27 January 2011), 46-47.

259 Bethroot Gwynn, interview with author (27 January 2011), 46.
} 
Now there are young women who are in southern Oregon, being on land. There are young women at Rootworks. There are young women around Gypsy Cafe, where the We'Moon offices are now, and they have a lot of WWOOFers ${ }^{260}$ that come in the summer, so when I say that there is ferment in the "I want to live on land. I want to build buildings. I want to garden." There is that rising tide that's going on among you young women, and partly for some of them I think they have very little interest in--or not much passion --about women-only land, because so many young women came out into queer culture where women-only space is not particularly sought after or valued or understood. I think that that's one of the problematics about how we define these lands, and you know, that may change in time to come. I don't like to say that. So sad to think about it. ${ }^{261}$

Whereas, Bethroot saw the possibility of a shift away from women-only land, Dana MacDonald of Steppingwoods, saw it as potential:

And the land down where Myshkin and Barb are, you know, Sunny Valley, Gypsy Cafe--they bring in a lot of new younger energy, the WWOOFers and so forth. So the whole collectivizing, so it's like carried on, and it's carried on in new ways and in old ways. Some lands are more open to men or transgenders and some aren't. Our land is always. We have women's events that are womenonly events, and we come up against some questioning about that, and rightly so. But we feel like we want to maintain that for certain women who do not feel safe in the presence of transgendered and/or male energies. ${ }^{262}$

While Dana acknowledged the tension between lesbian separatists and the current trend toward inclusion, she sees value and potential in both, and maintains the ability to actively engage each community depending on the event and its circumstances.

Furthermore, like many women within this community, she values the conversation,

${ }^{260}$ WWOOFers is a common term for temporary skilled farm labor, which comes from the international organization, World Wide Opportunities on Organic Farms. Many young people who have an interest in organic farming will join this network that connects them to farms throughout the world. It started in 1971 in the United Kingdom, and there are regional groups throughout the world. See http://www.wwoof.org/ 261 Bethroot Gwynn, interview with author (27 January 2011), 50-51.

262 Dana MacDonald, interview with author (13 January 2011), 19-20. 
saying that when they do hold women-only events others confront and question them on that and as she says: "rightly so.

In addition to political differences, the hardships and inconveniences of living on women's land required a certain amount of commitment that is not necessary in mainstream society. On the one hand, with the use of the Internet, one doesn't need to overcome physical hardships together to create community; there aren't the same obstacles or the need for living in proximity to connect with one another on an intellectual level. ${ }^{263}$ On the other hand, some of those same technologies could make living on land easier. Dana MacDonald described her understanding of the hardships of living at Cabbage Lane:

It's way way deep in a canyon, and it doesn't get any light in the winter, at all. It's very hard to live there. I mean, here there's very little light until it starts coming up--even being southern exposure, and so living there in the winter would be very very difficult. You would feel--I would feel really hemmed in, I think, on some level. ${ }^{264}$

Similarly, Bethroot described the hardships as part of the lack of attraction for

\section{OWL Farm:}

It's off the beaten track. It's as far off the freeway as--it's not quite as far off the freeway actually as Fly Away Home is. It's a little bit closer in, but it feels off the beaten track, so the nearest jobs would be in Canyonville, which is a fairly depressed area, economically. There is a big casino there, and women have

\footnotetext{
263 Some examples of these communities or connections include blogging, computer generated publications, and listservs. For a list of these see: http://www.wifp.org/DWM/Listservs.html This is a list put out by the Women's Institute for Freedom of the Press, but there are many others.

${ }^{264}$ Dana MacDonald, interview with author (13 January 2011), 23.
} 
sometimes had jobs at the casino, but how can you do a full-time job and live on women's land, and do the work of the land? It's really hard. And women who have been able to figure out how to live on women's land have usually had some kind of part-time employment. Either it's seasonal, you know, for two or three months at a time or it's--you know, a woman who lived at Rainbow's End once had a job in Eugene that was three days a week, so she'd go to Eugene for three days. OWL Farm is even more rustic than this land. It's not more rustic than Cabbage Lane, but there's no electricity. And there's no potable water. There's a well, so there's water, but it has to be filtered or boiled or chlorinated or something. And the structures that don't have women living in them get taken over by the rats, so one of the cabins at OWL Farm right now is still in pretty good shape. It's fairly clean. Another of the cabins, there hasn't been anybody living in it for long enough that there's beginning to be some rodent involvement....so the infrastructure at OWL Farm is not well developed, and so women are sometimes discouraged about living there. ${ }^{265}$

While there are resources available within the community that could potentially transform the situation at OWL Farm, none of the women want to invest in something without a population of women living there. For example, there are funds that could be made available to install solar panels to provide some electricity or improve the water system, but without women there year-round, the fear is that those materials could be stolen from the property. ${ }^{266}$ It appears that the dilemma is which comes first? Without these improvements, they've been unable to attract women to the land. Without women committed to the land, the women on the board are unwilling to commit the funds for improvements.

There have been times when women have come to OWL Farm, but it hasn't been long lasting. Bethroot described it in terms of personal disagreements, an inability to reach consensus, and "They way we've said it in the past is, 'Women, we bring our

\footnotetext{
265 Bethroot Gwynn, interview with author (27 January 2011), 42-43.

266 Bethroot Gwynn, interview with author (27 January 2011), 43.
} 
damage from patriarchy. We bring it to women's land,' and a lot of it was brought to OWL Farm over the years."267

Furthermore, not many young women today know that these lands still exist or their locations. Part of that is for the community's own security, and part of that is also the lack of electronic communication. While some women's lands do have Facebook pages, none of them have a website. A basic Google search of "women's lands in Oregon" or "lesbian communes in Oregon" will result in a handful of scholarly papers and the University of Oregon's SoCLAP! Archives, hardly the sign of a living community seeking new residents. ${ }^{268}$

There are many lands without younger women ready to take over for the aging populations, and most of the women who have spent any time at all on the southern Oregon women's land in the 1970s have since left. A small but important number of the founding women remain on or near the lands they helped create, and hope to marshal on to the next generation. Women have take the necessary steps, such as the establishment of land trusts, covenants, nonprofits with boards, and wills in a final effort to make these lands accessible to women in perpetuity. Their concern for the trees, wildlife, and natural resources as a part of the future of women's land is also reflected in these interviews. It remains to be seen whether the interest or need for this rural women-only space will survive. The popularity of feminist political engagement may be losing ground to a commitment to a more dynamic queer ethic that embraces a continuum of gender and sexual identities.

\footnotetext{
267 Bethroot Gwynn, interview with author (27 January 2011), 45.

268 See Bethroot's explanation. Bethroot Gwynn, interview with author (27 January 2011), 45-46.
} 


\section{Chapter 5: In Conclusion}

If you did not grow up with this shaping, this second-by-second fettering and questioning, you cannot really know what residue it leaves. You can empathize it, of course; human beings can and do have extraordinary powers of empathy. And empathy combined with observation and justice can build invaluable allies.

But if you were not raised as a girl, you cannot KNOW it. And you cannot acquire it by magical thinking, by attire and chemistry, or even by years living in a changed identity. Because once girlhood is past, it is past.

And sometimes I want, need, insist on conversing and exploring with those who were also raised as girls, just as sometimes I have to be with those raised poor or those raised disabled. I was targeted from birth and I deserve a chance to identify, for myself, the damage done to me by that targeting without having to simultaneously translate it for those who simply did not experience it.

I am offended when you assume I should not have that right, or that my need to heal and reclaim means I must somehow be oppressing you. I am offended when you shriek my right to self-definition of being born a target in the most lethally attacked subgroup in the world -- born female -- means your feelings are somehow hurt because you were born and raised nontarget for this particular ongoing genocide. And guess what: I reached adulthood in a world with feminism, which agrees that if I insist on my due space in this world, your feelings about it are YOUR feelings. Not. My. Problem.

-Maggie Jochild ${ }^{269}$

This quote from Maggie Jochild, one of the many women who came out of the

lesbian feminist movement, is the most perfect articulation of the crux of the issue

between those who value women-only space, and those who view it as antiquated,

\footnotetext{
269 Maggie Jochild is a writer, poet, intellectual, and revered elder in the lesbian community of Austin, Texas. She spent the 1970 s on the immersed in west coast radical lesbian feminism. The quote is from her blog: (http://maggiesmetawatershed.blogspot.com/2013/02/from-inside-girlhood.html) Accessed on February 18, 2013. Reprinted with author's permission. You can find more biographical information about her here: http:/ / auntlute.com/2667/guest-contributor/maggie-jochild-chasing-the-second-wave-in-sanfran/
} 
exclusionary, and even gender oppressive. The historic Michigan Womyn's Music Festival, which is also a product of this time period, has similarly faced a very public debate over gender identity in its womyn-born-womyn admissions policy. Who says who is a woman? Is gender biology, chromosomes, brain chemistry, or conscious choice? The boundary between what is male and what is female can often be blurred. ${ }^{270}$ Yet there are times, places, and people who value gender-limited spaces, and they are not necessarily outside of the mainstream. For example, most public places provide restrooms for 'men' and 'women.' There are girls' and boys' basketball teams, as well as entire schools dedicated to a single gender. Some religions place value on separating the genders during worship. There was a time when some of these gender specific spaces felt exclusionary toward women; prior to 1973, Portland's City Club was one such example. ${ }^{271}$

In the $1970 \mathrm{~s}$, a time in which women's lib was transitioning into what became popularly known as feminism, the southern Oregon lesbian land communities claimed their due space in the world. Women gathered their resources, purchased land, protected it, and created a community in which they could envision themselves and a future. They created a culture full of song, photographs, poetry, ritual, and art. They made their lives meaningful, and shared that meaning with women throughout the world. Their contributions to lesbian culture are visible in lesbian and queer culture today.

This thesis has provided evidence that the lesbian lands in southern Oregon had a significant impact on the development of lesbian feminist culture in the 1970s and 1980s. The second chapter examined how the lesbian land communities that were developed in

\footnotetext{
270 See for example: Judith Butler, Gender Trouble (New York: Routledge Classics, 2006), and http://www.michfest.com/, and http://eminism.org/michigan/faq-debate.html for more information. ${ }^{271}$ City Club of Portland website: http://pdxcityclub.org/content/city-club-history Accessed on April 30, 2013.
} 
southern Oregon in the 1970s created a safe space for women to recreate themselves, and placed it within the last twenty years of LGBTQ historiography that has examined the creation of safe gay and lesbian space since the early twentieth century. Then I examined how constructions of identity were expressed through workshops and creative materials that were sent out through media networks to have an impact on the wider lesbian feminist culture. As lesbian feminist culture developed and changed over time it had unintended consequences. The most impactful of these consequences has been the shaping in the 1990s of a new postmodernist queer theory that deconstructed the gender and sexual orientation identities upon which the lesbian feminist intentional lands and their culture rely. It could be argued that these communities provided the key for their own destruction.

One of the biggest issues presently facing lesbian lands is its adherence to the second wave feminist value of separatism. While the lesbian lands are not growing in population or popularity because of the politics of separatism, they have paved the way for new rural intentional communities that embrace all genders and no genders, lands that have taken feminism beyond the gender binary. These questions of gender and sexual identity, this connection between feminism and queer theory had its roots in the feminist consciousness raising groups of the 1960s and 1970s. While recent trends in queer theory question the construction of gender and sexual identity, the lesbian feminists who came before them questioned the definition and attributes of those same constructions. Just as queer theorists are exploring the wide range of sexual and gender identities and performance, there too exists a range in the theory and value of separatism. 
Zarod Rominski:

I know that my progress on that road has everything to do with relationships with people, and relationships with transpeople. I think if $I$ were living on the land, it would be a question of the individual, that I would be open to a transwoman--if I liked that woman. I mean, if I felt like this was a good person for the land, and also because I don't think we know. I don't think we're in a strong enough or clear enough place to know what this whole trans thing is about. A lot of the--I think a lot of the anti-trans sentiment is not that different from anti-dyke sentiment of decades ago, and you know--where is it going? I don't know. I think we just don't know, and I really support dialogue and respectful interaction. I mean, how can we know this--how can we figure this out in an intellectual way, you know, when it's people's lives and people's bodies and people's inner-sense of themself. And who am I to--who's anybody to pass judgment on that?

Then what does that mean in terms of women's land, that sanctuary for women? I don't know. And I don't think I will know. I don't think we will know until there is land that's women's land and welcomes transwomen, and we see what that's like. What does that mean? How does that feel? But again, I feel like it's individual too. I don't think you can say that all transwomen are gong to feel this way. You know, it's not going to be like that. So we had some conversation at Cabbage Lane about it, over the last ten years, not a lot--because we've never been approached. There's never been a request, but at the time we did have the conversation about it, we said--women were not living on the land, women were coming to use the land--visit, tent camp, you know, stuff like that--we said that the land would be open to transwomen for an event. Transwomen or if a mixed group of women and transwomen wanted to have an event there, that could happen. So that's what was said at one meeting, you know, ten years ago. Is it written down anywhere? Does everyone agree with it now? I have no idea, but that's where the feelings were of the women at that time, in that place. ${ }^{272}$

There is no answer. There is no way of knowing who will ultimately win the gender binary/queer deconstruction debate--all it does, as with most theorizing, is bring more questions to light. The two quotes presented in this conclusion by two woman-

272 Zarod Rominski, interview with author (13 May 2011), 33-34. 
identified-women make it apparent that there is no answer, no agreement, even between women of the same generation and with back-to-the-land roots. This debate is about human beings with human experiences and human feelings. It is a continuing conversation. It is a part of the history of the lesbian land movement documented here.

The history of the southern Oregon lesbian land movement is significant to this discussion, to our understanding of the history of Oregon, the history of the women's liberation movement, the history of the gay liberation movement, the history of intentional communities, the history of the United States, and the history of global communication. The lesbian land movement was a part of a worldwide movement to construct an affirmative gender and sexual identity in the face of systemic oppression. Their creative cultural contributions influenced a generation of lesbians, who have continued to impact the self-perception of lesbians the world over.

This thesis and the collection of oral histories now archived with the University of Oregon contributes to the existing scholarship in these areas. This research places the southern Oregon lesbian lands squarely within the history of the back-to-the-land movement within Oregon, within the women's liberation movement, the gay women's liberation movement, and the development of lesbian culture. While some of the women who were interviewed briefly mention the symbiotic relationship between some gay men's lands and lesbian lands, the stories of gay men's lands and their founders remain largely unrecorded and under-researched, and the affects of the AIDS pandemic on all of these communities deserves further investigation. The lesbian lands represent a small number of the intentional communities to come out of the 1970s back-to-the-land movement. As of yet, there has not been an extensive effort to collect the oral histories of the still living 
members of the1970s era communes in southern Oregon. In 1970, according to one woman, there were at least one hundred between the Washington and California borders, and on those communes there was a population that fluctuated seasonally.273 I have only collected the stories of eight women. There is more work to be done.

${ }^{273}$ See Miller, 67. And also Kopp, 133-168. 


\section{References}

Archives/Manuscripts

\section{Oral Histories}

Each of the following recorded interviews and their transcriptions are archived within a new collection, "Southern Oregon Lesbian Land Communities Oral History Collection," held by Special Collections \& University Archives, University of Oregon, Eugene, Oregon:

Tangren Alexander, interviewed by author 12 November 2010.

Tangren Alexander, interviewed by author 13 February 2011.

Jemma Crae, interviewed by author 13 January 2011.

Bethroot Gwynn, interviewed by author 3 January 2011.

Bethroot Gwynn, interviewed by author 27 January 2011.

Dana MacDonald, interviewed by author 13 January 2011.

Hawk Madrone, interviewed by author 28 January 2011.

Billie Miracle, interviewed by author 6 May 2011.

Jean Mountaingrove, interviewed by author 23 September 2010.

Jean Mountaingrove, interviewed by author 25 October 2010.

Zarod Rominski, interviewed by author 23 May 2011.

Feminist and Lesbian Periodical Collection, Coll. 257, Special Collections \& 
University Archives, University of Oregon, Eugene, Oregon.

Ruth Mountaingrove Photographs, Ruth Mountaingrove Papers, Collection 309, Special Collections \& University Archives, University of Oregon Libraries, Eugene, Oregon.

Ruth Mountaingrove Videotape Autobiography Collection 1988-1997, Ruth Mountaingrove Papers, Collection 309, Special Collections \& University Archives, University of Oregon Libraries, Eugene, Oregon.

So-CLAP! (Southern Oregon Country Lesbian Archival Project) Collection, 19741999, Special Collections \& University Archives, University of Oregon Libraries, Eugene, Oregon.

Sue, Nelly, Dian, Carol, Billie. Country Lesbians: The Story of the WomanShare Collective. Grants Pass, OR: WomanShare Books, 1976.

Tee A. Corinne Papers, 1966-2003, Coll 263, Special Collections \& University Archives, University of Oregon Libraries, Eugene, Oregon.

Association of Lesbian Intentional Communities. "Come to Oregon Women's Lands." http://alicinfo.com/pages/oregon.htm

Corinne, Tee, ed. "Community Histories: Living in Southern Oregon." SO CLAP! Files, Special Collections \& University Archives, University of Oregon Libraries.

Kaufer, Nelly. "The Story of Cabbage Lane." SO CLAP! Files, Special Collections \& University Archives, University of Oregon Libraries.

Community Publications

The Blatant Image: A Magazine of Feminist Photography 1981-1983.

Books and Articles

Abbot, Sidney, and Barbara Love. Sappho Was a Right-On Woman. New York: Stein and Day, 1972.

Armitage, Susan H. with Patricia Hart and Karen Weathermon, eds. Women's Oral History: The Frontiers Reader. Lincoln NE: University of Nebraska Press, 2002. 
"A Day in the Life of a Commune Dweller: 17-year-old Ty of Rainbow Farm." Eugene Register-Guard (August 29, 1971): B1.

Bailey, Beth and David Farber, eds. America in the Seventies. Lawrence, KS: University of Kansas, 2004.

Bates, Doug. "Lane County's Rural Areas Nurture Communal Lifestyle." Eugene Register-Guard (August 29, 1971): B1.

Beemyn, Brett, ed. Creating A Place For Ourselves: Lesbian, Gay, and Bisexual Community Histories. New York: Routledge, 1997.

Berkowitz, Edward D. Something Happened: A Political and Cultural Overview of the Seventies. New York: Columbia University Press, 2006.

Bestor, Arthur, Jr. Backwoods Utopias: The Sectarian Origins and the Owenite Phase of Communitarian Socialism in America, 1663-1829. Philadelphia: University of Pennsylvania Press, 1970.

Boag, Peter. "'Does Portland Need a Homophile Society?': Gay Culture and Activism in the Rose City between World War II and Stonewall." Oregon Historical Quarterly 105, no. 1 (2004): 6-40.

Bouvard, Marguerite. The Intentional Community Movement: Building a New Moral World. Port Washington, NY: Kennikat Press, 1975.

Boyd, Nan Alamilla. Wide-Open Town: a history of queer San Francisco to 1965. Berkeley: University of California Press, 2003.

Braunstein, Peter, and Michael William Doyle, eds. Imagine Nation: The American Counterculture of the 1960s and '70s. New York: Routledge, 2002.

Brown, Dona. Back to the Land: The Enduring Dream of Self-Sufficiency in Modern America. Madison: University of Wisconsin Press, 2011.

Brown, Rita Mae. A Plain Brown Rapper. Oakland, CA: Diana Press, 1976.

Bunch, Charlotte. "Learning from Lesbian Separatism." Ms. (November 1976): 60+.

Butler, Judith. Gender Trouble: Feminism and the Subversion of Identity. New York: Routledge, 1990.

Chauncey, George. Gay New York: Gender, Urban Culture and the Making of the Gay Male World, 1890-1940. New York: Basic Books, 1994. 
Cheney, Joyce. Lesbian Land. Minneapolis: Word Weavers, 1985.

Chmielewski, Wendy E., Louis J. Kern and Marlyn Klee-Hartzell eds. Women in Spiritual and Communitarian Societies in the United States. Syracuse, NY: Syracuse University Press, 1993.

Cloke, Paul and Jo Little, eds. Contested Countryside Cultures: Otherness, Marginalisation and Rurality. New York: Routledge, 1997.

Corbett, Rachel. "Women's Bookstores Dwindle to Stalwart Few." Women's Neres August 15, 2005. http://womensenews.org/story/books/050815/womensbookstores-dwindle-stalwart-few\#.UX8HOnHTlbw Accessed on April 28, 2013.

Corinne, Tee A. editor, Community Herstories: Living in Southern Oregon. (ca. 1990): Tee A. Corinne Papers, Coll. 263, Special Collections \& University Archives, University of Oregon, Eugene, Oregon.

Cott, Nancy F. The Grounding of Modern Feminism. New Haven, CT: Yale University Press, 1987.

D'Emilio, John. Sexual Politics, Sexual Communities: The Making of a Homosexual Minority in the United States 1940-1970, $2^{\text {nd }}$ ed. Chicago: The University of Chicago Press, 1983.

Duberman, Martin. Stonewall. New York: Dutton, 1993.

Echols, Alice. Daring To Be Bad: Radical Feminism in America, 1967-1975. Minneapolis: University of Minnesota Press, 1989.

Evans, Sara. Personal Politics: The Roots of Women's Liberation in the Civil Rights Movement and the New Left. New York: Vintage Books, 1979.

Evans, Sara, and Harry Boyte. Free Spaces. Chicago: University of Chicago Press, 1992.

Faderman, Lillian. Odd Girls and Twilight Lovers. A History of Lesbian Life in Twentieth Century America. New York: Penguin Books, 1991.

Fairfield, Richard. The Modern Utopian Communes, Europe. San Francisco, CA: Alternatives Foundation, 1972.

Firestone, Shulamith. The Dialectic of Sex: the Case for Feminist Revolution. New York: Bantam Books, 1970.

Flanagan, Kent. "Farmhouse Stormed; Suspect Not There," Oregonian. February 16, 
1983, A12, Portland edition.

Foucault, Michel. The History of Sexuality Volume 1: An Introduction. New York: Random House, Inc., 1978.

Freedman, Estelle. "Separatism as Strategy: Female Institution Building and American Feminism, 1870-1930." Feminist Studies 5/3 (Fall 1979): 512-29.

Fuss, Diana. Essentially Speaking: Feminism, Nature, and Difference. New York: Routledge, 1989.

Gaard, Greta, ed. Ecofeminism: Women, Animals, Nature. Philadelphia: Temple University Press, 1993.

Gagehabib, LaVerne, and Barbara Summerhawk. Circles of Power: Shifting Dynamics in a Lesbian-Centered Community. Norwich, VT: New Victoria Publishers, 2001.

Gilman, Charlotte Perkins. Herland. New York: Pantheon, 1979.

Gwynn, Bethroot. "Landed." Sinister Wisdom 63 (2004).

Hanhardt, Christina B. "Butterflies, Whistles, and Fists: Gay Safe Streets Patrols and the New Gay Ghetto, 1976-1981." Radical History Review 100 (Winter 2008): 61-85.

Herring, Scott. Another Country: Queer Anti-Urbanism. New York: New York University Press, 2010.

Hine, Robert V. California Utopianism: Contemplations of Eden. San Francisco, CA: Boyd \& Fraser, 1981.

Hoagland, Sarah and Julia Penelope, eds. For Lesbians Only: A Separatist Anthology. London: Onlywomen Press, 1988.

Hogan, Kristen A. "Defining Our Own Context: The Past and Future of Feminist Bookstores." thirdspace: a journal of feminist theory $\mathcal{E}^{\circ}$ culture, volume 2 issue 2. (March 2003) http://www.thirdspace.ca/journal/article/view/hogan/114 Accessed on April 28, 2013.

Hogan, K. A. (2006). Reading at feminist bookstores: Women's literature, women's studies, and the feminist bookstore network. The University of Texas at Austin). ProQuest Dissertations and Theses, , 359-359 p. Retrieved from http://search.proquest.com/docview/304984076? accountid=13265. (304984076). 
Hollis, Daniel W., III. The ABC-CLIO Companion to Utopian Movements. Santa Barbara: ABC-CLIO, 1998.

Howard, John. Men Like That: A Southern Queer History. Chicago: University of Chicago Press, 1999.

Ingram, Gordon Brent, Anne-Marie Bouthillette, and Yolanda Retter, eds. Queers in Space: Communities/Public Spaces/Sites of Resistance. Seattle: Bay Press, 1997.

Jacob, Jeffrey. New Pioneers: The Back-to-the-Land Movement and the Search for a Sustainable Future. University Park, PA: The Pennsylvania State University Press, 1997.

Jay, Karla and Allen Young, eds. Out of the Closet: Voices of Gay Liberation. New York: New York University Press, 1992.

Johnson, David. "Greener Grass: A Short History of Oregon's Utopian Tradition." Oregon Heritage 1 (Winter/Spring, 1995): 17.

Johnston, Jill. Lesbian Nation: The Feminist Solution. New York: Simon and Schuster, 1973.

Kanter, Rosabeth Moss. Commitment and Community: Communes and Utopias in Sociological Perspective. Cambridge, MA: Harvard University Press, 1972.

Kennedy, Elizabeth Lapovsky and Madeline D. Davis. Boots of Leather, Slippers of Gold: The History of a Lesbian Community. New York: Routledge, 1993.

Kerber, Linda K. et al., eds. U.S. History as Women's History: New Feminist Essays. Chapel Hill: University of North Carolina Press, 1995.

Kheel, Marti. "Ecofeminism and Deep Ecology: Reflections on Identity and Difference." In Reweaving the World: The Emergence of Ecofeminism. Edited by Irene Diamond and Gloria Orenstein. San Francisco: Sierra Club Books, 1990.

Kinkade, Kathleen, A Walden Two Experiment: The First Five Years of Twin Oaks Community. New York: William Morrow \& Company, 1973.

Kleiner, Catherine B. "Doin' It for Themselves: Lesbian Land Communities in Southern Oregon, 1970-1995." Ph.D. Dissertation, University of New Mexico, 2003.

Kolmerten, Carol A. Women In Utopia: The Ideology of Gender in the American Owenite Communities. Bloomington, IN: Indiana University Press, 1990. 
Koolish, Lynda. "Country Women: The Feminists of Albion Ridge." Mother fones (April 1978): 23-32.

Kopp, James. Eden Within Eden: Oregon's Utopian Heritage. Corvallis: Oregon State University Press, 2009.

Kuhlmann, Hilke. Living Walden Two: B.F. Skinner's Behaviorist Utopia and Experimental Communities. Chicago: University of Illinois Press, 2005.

Laffan, Barry. Communal Organization and Social Transition: A Case Study from The countercultures of the Sixties and Seventies. New York: Peter Lang, 1997.

Lee, Pelican. OWL Farm Stories. Ribera, NM: West Wind: 2002.

Luis, Keridwen N. "Ourlands: Culture, Gender, and Intention in Women's Land Communities in the United States." PhD diss., Anthropology, Brandeis University, 2009.

Love, Barbara J. Feminists Who Changed America 1963-1975. Urbana: University of Illinois Press, 2006.

Madrone, Hawk. Weeding At Dawn: A Lesbian Country Life. New York: Alice Street Editions, 2000.

Manalansan IV, Martin F. Global Divas: Filipino Gay Men in the Diaspora. Durham, NC: Duke University Press, 2003.

Marcus, Eric. Making History: The Struggle for Gay and Lesbian Equal Rights 19451990. New York: Harper Collins, 1992.

McAdam, Douglas. Freedom Summer. New York: Oxford University Press, 1988.

McLaughlin, Corinne, and Gordon Davidson. Builders of the Dawn: Community Lifestyles in a Changing World. Walpole, NH: Stillpoint Pub., 1985.

Mellor, Mary. Feminism and Ecology. New York: New York University Press, 1997.

Merchant, Carolyn. The Death of Nature: Women, Ecology and the Scientific Revolution. San Francisco: Harper \& Row, 1983.

Mikels, Elaine. Fust Lucky I Guess: From Closet Lesbian to Radical Dyke. Santa Fe: Desert Crone Press, 1993.

Miller, Timothy. The Hippies and American Values. Knoxville: University of 
Tennessee Press, 1991.

Miller, Timothy. The 60s Communes: Hippies and Beyond. Syracuse, New York: Syracuse University Press, 1999.

Minato, Amy. Siesta Lane: One Cabin, No Running Water, and a Year Living Green. New York: Skyhorse Publishing, 2009.

Moraga, Cherríe, Gloria Anzaldúa, and Toni Cade Bambara, eds. This Bridge Called My Back: Writings by Radical Women of Color. New York: Kitchen Table Women-of-Color Press, 1981.

Morgan, Robin, ed. Sisterhood Is Powerful: An Anthology of Writings from the Women's Liberation Movement. New York: Random House, 1970.

Mungo, Raymond. Total Loss Farm: A Year in the Life. New York: E.P. Dutton \& Co., 1970.

Musawa, narrator. In the Spirit of We'Moon: Celebrating 30 Years. Estacada, OR: Mother Tongue Ink, 2010.

Narayan, Uma and Sandra Harding, eds. Decentering the Center: Philosophy for a Multicultural, Postcolonial, and Feminist World. Bloomington: Indiana University Press, 2000.

Newton, Esther. Cherry Grove, Fire Island: Sixty Years in America's First Gay and Lesbian Town. Boston: Beacon Press, 1993.

Olmos, Bob. "Conflict in The Valley of The 'Wasps'," The Sunday Oregonian. April 27, 1969:169.

Oregonian. issues between 1967 and 1982.

Patterson, Alexander. "Terrasquirma and the Engines of Social Change in 1970s Portland." Oregon Historical Quarterly 101 (Summer 2000): 162-91.

Perks, Robert and Alistair Thomson, eds. The Oral History Reader, Second Edition. New York: Routledge, 2006.

Phelan, Shane. Getting Specific: Postmodern Lesbian Politics. Minneapolis: University of Minnesota Press, 1994.

Phelan, Shane. Identity Politics: Lesbian Feminism and the Limits of Community. Philadelphia: Temple University Press, 1989.

Ritchie, Donald A. Doing Oral History: A Practical Guide, Second Edition. New York: 
Oxford University Press, 2003.

Rominski, Frances. "Star Building," in The Woman's Carpentry Book: Building Your Home from the Ground Up, edited by Jeanne Tetrault. New York: Anchor Press, 1980, 190-199.

Roth, Benita. Separate Roads to Feminism: Black, Chicana, and White Feminist Movements in America's Second Wave. New York: Cambridge University Press, 2004.

Sargisson, Lucy. Contemporary Feminist Utopianism. New York: Routledge, 1996.

Seligman, Adam B. and Robert P. Weller. Rethinking Pluralism: Ritual, Experience, and Ambiguity. Oxford: Oxford University Press, 2012.

Shewolf. Shewolf's Directory of Wimmin's Lands. New Orleans: Royal T Publishers, 2000.

Shugar, Dana. Separatism and Women's Community. Lincoln: University of Nebraska Press, 1995.

Snell, John. "Ready for Worst Survivalists Secure in Oregon," The Sunday Oregonian. February 1, 1981, front page, Portland edition.

Sprecher, Katharine Matthaei. "Lesbian Intentional Communities in Rural Southwestern Oregon: Discussions on Separatism, Environmentalism, and Community Conflict." M.A. thesis, California Institute of Integral Studies, 1997.

Starhawk. Dreaming the Dark: Magic, Sex and Politics. Boston: Beacon Press, 1982.

Sullivan, Nikki. A Critical Introduction to Queer Theory. New York: New York University Press, 2003.

Warren, Karen J. Ecofeminism: Women, Culture, Nature. Bloomington: Indiana University Press, 1992.

Weaver, Sharon. "First Encounters: 1970s Back-to-the-land Cape Breton, NS and Denman Hornby and Lasqueti Islands, BC," Oral History Forum d'histoire orale 30 (2010) Special Issue "Talking Green: Oral History and Environmental History.

Weed, Elizabeth and Naomi Schor, eds. feminism meets queer theory. Bloomington, IN: Indiana University Press, 1997.

Wilner, Joseph Bear. "All My Sisters and Brothers: Redefinitions of Family in 
Oregon Intentional Communities During the Late Twentieth Century." M.A. thesis, University of Oregon, 2000.

Witt, Lynn and Sherry Thomas, and Eric Marcus, eds. Out in All Directions: The Almanac of Gay and Lesbian America. New York: Warner Books, 1995.

Younger, J. Milton. countercultures: The Promise and Perils of a World Turned Upside Down. New York: The Free Press, 1982.

Electronic Sources:

Cook, Tom. (revised by George Painter), 1999 Portland Gay History Walking Tour, http://www.glapn.org/6045walkingtour.html (accessed 08/10/2012).

Jochild, Maggie. Maggie Jochild's blog, Maggie's Meta Watershed, http:/ / maggiesmetawatershed.blogspot.com/2013/02/from-inside-girlhood.html (accessed on February 18, 2013). 
Appendix

Women's Land Chronology

1762: Sarah Scott's A Description of Millennium Hall is published.

"After a failed marriage, Scott and a female friend established a female commune in 1754, which became the factual basis for the fictional Millennium Hall." (Daniel W. Hollis III, The ABC-CLIO Companion to Utopian Movements (Santa Barbara: ABC-CLIO, 1998): 69).

1826: Frances Wright starts a feminist settlement in Nashoba, Tennessee.

1889:

1915: Charlotte Perkins Gilman's Herland is first published as installments in her newspaper, The Forerunner.

1948: B.F. Skinner publishes Walden Two.

1963: August 28. The March on Washington for Jobs and Freedom.

1964: 1964 Civil Rights Act.

1965: President Johnson escalates the war in Vietnam.

1966: Carl Wittman married New Left leader, Mimi Feingold, in a hippie-style wedding in a pasture on the New Jersey farm of the prominent New Left elder, Dave Dellinger (1915-2004).

1967: Wittman moves to San Francisco.

Herbert Marcuse's The End of Utopia is published.

Kathleen Kinkade founds Twin Oaks, a Virginia commune based on B.F. Skinner's Walden Two.

1968: The Advocate starts publication.

June 6. Robert F. Kennedy was assassinated.

1969: May. Carl Wittman publishes his "A Gay Manifesto."

The first moon landing. 
Frances-Monique Wittig publishes Les Guérillères.

June 28. The Stonewall Inn riots begin.

1970: Kate Millet publishes Sexual Politics.

1971: Jemma and her girlfriend, JP, begin looking for land in Oregon. (Jemma's interview, page 11, lines 228-237.)

Carl Wittman moves permanently to his property outside of Wolf Creek, Oregon (Golden).

1972: Cabbage Lane was bought by a group of hippies, which included one gay man and other men and women in various stages of bisexuality or coming out (Nelly [Ellen]Kaufer, Bob, Richard [Landon] Corbin, Patti, Willie, and Amy). "It was a cheap 80 acres--a steep wooded canyon near Wolf Creek in the mountains of southern Oregon." (Lesbian Land, Cheney ed. "NOZAMA TRIBE" by Pelican Lee, p. 152).

1973: The first exclusively women's land is purchased outside of Portland (first known as WHO Farm, then We'Moon Healing Ground, and finally We'Moon Land. Home of We'Moon Datebook).

1974: Carl Wittman is a part of a small group that establishes the gay back-to-the-land magazine, RFD (Rural Free Delivery), although "RFD"'s definition changes with each issue: "Rustic Fairy Dreams," "Reckless Fruit Delight," "Really Feeling Divine," and so on. Its publication location changes regularly as well, moving from one rural gay commune to another.

The WomanShare Collective (Carol, Billie, and Dian) is formed outside of Grants Pass, Oregon. WomanShare began as a group of five women from Montreal. It becomes home to more than thirty women for varying lengths of time.

Spring. Cabbage Lane was divided between the men and the women. 60-acres became Cabbage Lane, women's land, and 20--acres up on the ridge became Lavender Ridge or Lilac Ridge (depending on who you talk to), men's land. At that time there was only one man still involved on the land.

Jean and Ruth Mountaingrove began publication of WomanSpirit, a quarterly journal.

The Dispossessed: An Ambiguous Utopia by Ursula Le Guin is published.

1975: Rainbow's End is established outside of Roseburg.

Jemma Crae and JP begin building a cabin at Steppingwoods (Jemma's interview, page 12). 
June. A three-day workshop was held at WomanShare called "Money, Class, and Power." This is were the initial idea of a land trust was formed. (WomanSpirit 1977, and reprinted in Community Herstories -not pink-page 27; Pelican Lee "NOZAMA TRIBE" in Lesbian Land edited by Cheney, p. 158)

July. WomanSpirit festival. There was a workshop on land trusts.

The original 80-acres that was Cabbage Lane was paid off by 1975; the entire land had been purchased for $\$ 8,000$. One of the residents of Cabbage Lane had been given money from the Portland divorce settlement, and she used her money to pay off what was owed on the land. She also, then gave $\$ 900$ to each lesbian in the Wolf Creek community (about 20 of them). (from Lesbian Land, Cheney ed. "NOZAMA TRIBE" by Pelican Lee, p. 155)

October. The first formal Oregon Women's Land Trust meeting was held in Vida, Oregon, 70 women attended, and the articles of incorporation were voted on. The Articles of Incorporation:

To acquire, administer, and hold in perpetuity land and other assets in trust for the benefit of women who would otherwise be denied such access.

To promote, explore, develop and maintain the spiritual, physical, and cultural well being of women by:

providing women access to land, encouraging self-sufficiency and the means to attain it, fostering and exploring new patterns of human relations, and providing other experiences to promote the well-being of women.

To encourage thereby the development of harmonious and ecologically sound land-based communities.

To preserve land and protect it from speculation and over-development, and to foster the recognition of land as a sacred heritage and resource belonging to all.

to serve as a resource for individuals and groups of women with interests in any of the above. (WomanSpirit 1 1, 1977, and reprinted in Community Herstories -not pink-page 27; from Lesbian Land, Cheney ed. "NOZAMA TRIBE" by Pelican Lee, p. 158).

1976: WomanShare Collective wrote a book, Country Lesbians, the Story of the WomanShare Collective.

Spring. There is a hippie spring fair in Roseburg, and Jemma \& JP meet Bethroot (Fly Away Home) and Francis (Rainbow's End)--she tells her neighbor, Thwing, that "we found our community!" (Jemma's interview, page 13).

March. The second meeting of the Oregon Women's Land Trust was held in Grays Creek, and some women volunteered to look for land (WomanSpirit 11, 1977, and reprinted in Community Herstories -not pink-page 27). 
May. The third meeting of the Oregon Women's Land Trust was held at Who Farm in Estacada. Some of the women had found 147-acres of land in Days Creek, and had put some money down to hold it until the meeting. The decision was made to purchase the land (WomanSpirit 11, 1977, and reprinted in Community Herstories -not pink-page 27).

summer. The Oregon Women's Land Trust signed a contract to buy OWL Farm. The down payment of $\$ 18,500$ was paid, and monthly payments were to be $\$ 365$. (Pelican Lee "NOZAMA TRIBE" in Lesbian Land edited by Cheney, p. 159)

July. The Oregon Women's Land Trust meeting was held at the Days Creek land, which became known as OWL Farm. Nearly 100 women attended. 17 women and 2 girl children moved onto the land (WomanSpirit 11, 1977, and reprinted in Community Herstories -not pink-page 28; Pelican Lee "NOZAMA TRIBE" in Lesbian Land edited by Cheney, p. 159).

summer. A fire at WomanShare destroyed one of the cabins and its contents. There was also a fire that destroyed 185-acres of land at Covello, which left a number of women homeless (WomanSpirit 11, 1977, and reprinted in Community Herstories -not pink-page 28).

October. Land Trust meeting at OWL Farm. There was a pregnant woman who had previously been institutionalized, and a number of OWL Farm residents expressed their concerns about her. She "refused to believe she was pregnant (Pelican Lee "NOZAMA TRIBE" in Lesbian Land edited by Cheney, p. 159)." (WomanSpirit II 1977, and reprinted in Community Herstories -not pink-page 28).

November. There was a meeting at Rainbow's End in Roseburg to talk about land ownership (WomanSpirit II, 1977, and reprinted in Community Herstories -not pink-page 28).

November. There was a Land Trust meeting at Who Farm, and Who Farm was made a part of the land trust (WomanSpirit II, 1977, and reprinted in Community Herstories -not pinkpage 28).

1977: January 9. There was a women's Sunday brunch held at the Mountain Moving Cafe in Portland to raise money for the land trust (WomanSpirit II, 1977, and reprinted in Community Herstories -not pink-page 28).

January 15. There was a land trust benefit at the Mountain Moving Cafe in Portland (WomanSpirit 1977, and reprinted in Community Herstories -not pink-page 28).

January 15. The financial meeting was held in Eugene (WomanSpirit 1977, and reprinted in Community Herstories -not pink-page 28).

The lesbian land community begins discussions around issues of "open" versus "closed" communities. 
1978: spring. Almost all of the original collective members had left OWL, and the children's school at Cabbage Lane had folded. ("Oregon Women's Land Trust" in Maize \#3, 85; reprinted in Community Herstories -not pink-p. 41)."By 1978 all of the women I had lived with at Cabbage Lane had left." (from Lesbian Land, Cheney ed. "NOZAMA TRIBE" by Pelican Lee, p. 156)

San Francisco's first openly gay city supervisor, Harvey Milk, is murdered.

Ruth and Jean Mountaingrove purchase Rootworks.

Suzy Charnas publishes Motherlines.

1979: Natalie Barney was built at Rootworks.

The first Ovular is held at Rootworks.

Sally Gearhart's The Wandergound is published.

Charlotte Perkins Gilman's Herland is republished in book form.

Donna Young's book Retreat is published.

1980: summer. Ovular II

The women from the Ovulars, who were interested in creating a magazine, put out notices and calls for photographs in newsletters and magazines, such as Ms. They received over 600 photographs from more than 100 women. They held their first production meeting in March. (The Blatant Image, 1981, p. 2)

December 6. Martha Courtot, a poet, holds a writers' workshop at the Grants Pass Art Museum.

1981: February 14. The first writers' group meeting is held at RiverHouse in Murphy, Oregon. (Community Herstories (not pink), "Herstory" by Caroline Overman, p. 70)

The first issue of The Blatant Image is published, as "personal solutions which grew to political proportions." -Jean Mountaingrove (The Blatant Image, April, 1981)

July. Rootworks hosts Ovular III.

August. After a change in the population of OWL Farm, conflicts arose over race, class, and space. Mediation failed, and violence erupted. "All wimmin but two left OWL feeling it wasn't safe to be there. Efforts were made to evict the two, as they were involved in the violence, but they didn't leave until May 1982." (Oregon Women's Land Trust" in Maize \#3, 85; reprinted in Community Herstories -not pink-p. 41) 
1982: Jemma Crae begins doing production work, starting with a slide show about "Boston Marriages" in the 1800s. (Jemma's interview, page 18)

March 21. Tangren Alexander comes up with the full name: Oregon Women Writers' Group, Gourmet Eating Society and Chorus. "It was, by then, entirely apt; we had been practising for Hannah's musical, and our modest sandwich lunches had evolved into exotic pot-lucks." (Community Herstories (not pink), "Herstory" by Caroline Overman, p. 71)

Two Japanese women live at WomanShare.

The lesbian land community publishes the second issue of The Blatant Image.

Some women from the Bay Area who had participated in the Ovulars wanted to publish a photography magazine in the Bay Area, and subsequently the first issue of CounterVision: a photo-journal on cultural diversity in the community of women is published. (The Blatant Image, 1982, p.2)

1983: June 11-18. Rootworks hosts Ovular V.

The southern Oregon lesbian land community publishes The Blatant Image III (1983).

1984: There are seven lesbians living at WomanShare. One is a Swiss woman. (from Cheney's Lesbian Land, page 150, "WomanShare Fall 1984" by Jo Olszewska)

Jemma Crae (Marcia Lamphere) adopts her name. "It was a great time--learning about myself, learning about who I am, and having good friendships. About that time, let's see that was 1984, that was when I changed my name. I changed my name, my address, my telephone number, and my place of living, so I was a new person. I could be anybody I wanted to be. It was just like I was creating myself, my real self from what I was." (Jemma's interview, page 17.)

1986: summer. WHO Farm changed name to Womyn's Healing Ground at Estacada. (Maize \#9, summer 1986)

1987: "Pieces of Truth," Personal Theater directed by Bethroot Gwynn.

1988: Billy Russo, a gay male friend of Jemma Crae, began Ruby House, a home for people with AIDS in Winston, Oregon. The first volunteers at Ruby House came from the Lesbian and Gay Community of rural southern Oregon, especially from the Gay \& Lesbian Community Center in Roseburg. At the time, it was the only rural Gay \& Lesbian Community Center in the USA. (see Jemma's interview, page 35; www.harmreductioncenter.org/harm_reduction_center_of_/2008/02/ruby-house1988.html) 
1990: WomanShare had a total of 225 overnight visitors (self-reported in the WomanShare Newsletter, April 1991).

1991: OWL Farm had 10 residents, and over 75 visitors over the summer. (self-reported by NíAódagaín in Maize \#27 Winter 91, and reprinted in Community Herstories, [not the pink] p. 46)

Ruby House moved to Roseburg, Oregon.

April 20. "Childtracks and Amazon Wings," a Personal Theater Performance for women, directed by Bethroot Gwynn, assisted by Hawk Madrone, is performed in Roseburg. (performers are Jane Mara, Jeanne Kincaid, kaseja O., Sunny McHale SkyeDancer, and Susan Buckles.)

April 27. "Childtracks and Amazon Wings," a Personal Theater Performance for women, directed by Bethroot Gwynn, assisted by Hawk Madrone, is performed in Portland at Westminster Presbyterian Church.

May 11. "Childtracks and Amazon Wings," a Personal Theater Performance for women, directed by Bethroot Gwynn, assisted by Hawk Madrone, is performed in Eugene at Condon School.

June 28. David S. and Landon Corbin, the two remaining men who own shares of the land adjoining Cabbage Lane, write to Jean Mountaingrove expressing a desire to sell their shares to the women. (SOCLAP! Collection 266, Box 11, Folder 1). This marks the beginning of community discussions about the land purchase. At this time, no one is living at Cabbage Lane, and the buildings and trails have fallen into disrepair.

July 12, 13, 14. 18th Annual Women's Gathering at Mountain Lakes Camp outside of Klamath Falls.

The first Dyke Art Camp is held at Rootworks (Jemma's interview, page 22).

1992: Clarissa Pinkola Estes' book, Women Who Run With The Wolves, is published.

1993: Cabbage Lane, Inc., the Cabbage Lane Land Trust is established (SOCLAP!

Collection 266, Box 11, Folder 1).

1995: Jemma designed the home she lives in now, hired Osima and Julie, and they built her home, named Woodsong. (Jemma's interview, page 18.)

1998: Roseburg's Ruby House closes its doors. It later becomes a hospice house owned by Mercy Hospital 